\title{
Design and evaluation of a teaching portfolio
}

Citation for published version (APA):

Tigelaar, E. H. (2005). Design and evaluation of a teaching portfolio. [Doctoral Thesis, Maastricht University]. Datawyse / Universitaire Pers Maastricht. https://doi.org/10.26481/dis.20051207et

Document status and date:

Published: 01/01/2005

DOI:

10.26481/dis.20051207et

Document Version:

Publisher's PDF, also known as Version of record

\section{Please check the document version of this publication:}

- A submitted manuscript is the version of the article upon submission and before peer-review. There can be important differences between the submitted version and the official published version of record.

People interested in the research are advised to contact the author for the final version of the publication, or visit the DOI to the publisher's website.

- The final author version and the galley proof are versions of the publication after peer review.

- The final published version features the final layout of the paper including the volume, issue and page numbers.

Link to publication

\footnotetext{
General rights rights.

- You may freely distribute the URL identifying the publication in the public portal. please follow below link for the End User Agreement:

www.umlib.nl/taverne-license

Take down policy

If you believe that this document breaches copyright please contact us at:

repository@maastrichtuniversity.nl

providing details and we will investigate your claim.
}

Copyright and moral rights for the publications made accessible in the public portal are retained by the authors and/or other copyright owners and it is a condition of accessing publications that users recognise and abide by the legal requirements associated with these

- Users may download and print one copy of any publication from the public portal for the purpose of private study or research.

- You may not further distribute the material or use it for any profit-making activity or commercial gain

If the publication is distributed under the terms of Article $25 \mathrm{fa}$ of the Dutch Copyright Act, indicated by the "Taverne" license above, 


\title{
Design and Evaluation of a Teaching Portfolio
}

\author{
Dineke Tigelaar
}

Universiteit Maastricht

Maastricht, 2005 


\section{ico}

Dit onderzoek werd uitgevoerd in het kader van het Interuniversitair Centrum voor Onderwijsonderzoek. Het onderzoek is gefinancierd door NWO/PROO, aanvraagnummer 411-21-202.

Druk Datawyse Maastricht www.datawyse.nl

Uitgever Universitaire Pers Maastricht

Omslag Vormgeving: Datawyse Maastricht

ISBN 90-5278-493-0

(C) Dineke Tigelaar, Maastricht, 2005

Niets uit deze uitgave mag worden verveelvoudigd, opgeslagen in een geautomatiseerd gegevensbestand of openbaar gemaakt worden in enige vorm of op enige wijze, hetzij elektronisch, mechanisch of door fotokopieën, opname, of op enige andere manier, zonder voorafgaande schriftelijke toestemming van de auteur.

All rights reserved. No part of this publication may be reproduced, stored in a retrieval system, or transmitted in any form, or by any means, electronic, mechanical, photocopying, recording or otherwise, without the prior permissions in writing, from the author. 


\title{
Design and Evaluation of a Teaching Portfolio
}

\author{
PROEFSCHRIFT
}

Ter verkrijging van de graad van doctor aan de Universiteit Maastricht, op gezag van de Rector Magnificus

Prof. mr. G.P.M.F. Mols,

volgens het besluit van het College van Decanen,

in het openbaar te verdedigen op

woensdag 7 december 2005 om 14.00 uur

door

Egberdine Hillegonda Tigelaar

geboren op 10 oktober 1975 te Assen.

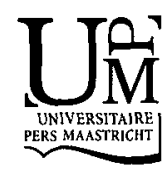


Promotor

Prof. dr. C.P.M. van der Vleuten

Copromotores

Dr. D.H.J.M. Dolmans

Dr. H.A.P. Wolfhagen

Leden beoordelingscommissie

Prof. dr. A.J.J.A. Scherpbier (voorzitter)

Prof. dr. G.T.M. ten Dam, Universiteit van Amsterdam

Prof. dr. J.F.M. Metsemakers

Prof. dr. M. Segers, Universiteit Leiden / Universiteit Maastricht

Dr. J. van Tartwijk, Universiteit Leiden 


\section{Dankwoord}

De periode waarin ik aan mijn proefschrift heb gewerkt, zie ik als een onvergetelijke en zeer waardevolle tijd. Verschillende mensen hebben daaraan een belangrijke bijdrage geleverd. Een aantal van hen wil ik hier bedanken.

Allereerst de mensen die direct betrokken waren bij het project.

Cees van der Vleuten, met jou als promotor had ik het heel goed getroffen. Je positieve manier van feedback geven en het vertrouwen dat je keer op keer in mij uitsprak, hebben mij zeer gestimuleerd.

Met veel plezier denk ik terug aan de discussies met mijn copromotoren Diana Dolmans en Ineke Wolfhagen. Zowel inhoudelijk als procesmatig waren jullie fantastische begeleiders. Nooit hoefde ik lang te wachten op feedback en ik kon altijd binnen lopen met een vraag. Jullie kritische, maar ook zeer persoonlijk-betrokken coachingswijze zal mij altijd bijblijven. Ik heb veel van jullie geleerd!

Alle experts die deelnamen aan het Delphi-onderzoek en het becommentariëren van het prototype portfolio, hartelijk dank voor de inbreng van jullie expertise.

Jan van Tartwijk, gedurende het hele project was jij een belangrijke en prettige sparring-partner, dank daarvoor!

De docenten en coaches die betrokken waren bij het uitproberen van het portfolio, ik waardeer jullie enorme inzet. Al gaven jullie aan, deelname heel zinvol te hebben gevonden, het was veel wat ik van jullie vroeg.

Willem de Grave, jij was altijd bereid mee te denken en mee te werken bij het praktisch vormgeven van het docentportfolioproject en je enthousiasmeerde mij steeds weer.

Albert Scherpbier, ook jou ben ik dankbaar voor je rol in de praktische fase van het project.

Mereke Gorsira, veel dank voor het corrigeren van de Engelse teksten en de boeiende inhoudelijke discussies die we daarna regelmatig hadden.

De leden van de beoordelingscommissie van mijn proefschrift, dank voor het zorgvuldig lezen van het manuscript.

Ook mijn werkomgeving maakte de afgelopen periode waardevol. Alle medewerkers van O\&O, wat zijn jullie fijne collega's! De sfeer op de afdeling was heel prettig en ook dank zij jullie ging ik elke dag met plezier naar mijn werk.

Speciaal wil ik de Promovendi noemen met wie ik intensief heb opgetrokken. Agnes Wagenaar, Astrid Visschers-Pleijers, Alexandra Jacobs, Susan Niemantsverdriet en Theo Niessen, wat hebben wij een geweldige AiO- 
tijd beleefd samen! Op het werk, maar ook daarbuiten. Ik denk aan onze (in)formele inhoudelijke overleggen, tussentijdse feedback en de intervisie, de cursussen en congressen die we samen volgden, de lunch(wandelingen) en de borrels in Thembi. Jullie betrokkenheid, gezelligheid en steun waren fantastisch! Astrid en Theo, jullie waren gezellige kamergenoten en maatjes!

Tevens dank aan de andere Promovendi van de UM die deelnamen aan de zesweekse literatuursessies voor de boeiende discussies en uitwisseling van gezichtspunten.

Liesbeth Baartman, AiO bij de Open Universiteit: het was prettig samenwerken met jou tijdens de voorbereidingen van de discussiemiddagen over assessment voor medewerkers van het OTEC en O\&O!

Ook een aantal anderen maakten de afgelopen jaren tot een bijzondere tijd. Bijvoorbeeld de leden van de Gereformeerde kerk in Maastricht, in het bijzonder buurtkring Zuid. Het was goed om met jullie samen te zoeken naar betekenis in het leven met God.

Verder denk ik aan Anne Creemers, Ren Lantman, Fieke Stoffers en Mathieu Vermeulen met wie ik vele plezierige muzikale uren heb beleefd tijdens ensemble-repetities en optredens.

En aan mijn vrienden, van wie ik enkelen hier wil noemen. Henrieke Hommes, dank voor de gezellige weekenden en vakanties en voor je steun, ook vanuit Uganda.

Angela Stoof, vanwege ons beider onderzoek naar competenties maakten we kennis. Ik vind het heel bijzonder dat we steeds meer raakvlakken ontdekten zoals onze gedeelde interesse in religie en onze opvattingen over wetenschap (bedrijven).

Agnes Wagenaar, jou wil ik nog een keer noemen. In de eindfase van mijn proefschrift heb je me enorm gesteund, o.a. bij het layouten. Ik denk met heel veel plezier terug aan onze gesprekken tijdens de bijna dagelijkse wandelingen in het Savelsbosch.

Gerard en Marjanne Markerink, Bert Hoekzema, Paola Kap-Wijma en Annemieke van den Broek-Arendsen, ik heb zeer genoten met jullie tijdens onze wandelingen in het Limburgse heuvelland en de weekendjes in de Ardennen.

Natasja van Veen, gedurende de tijd dat we beiden in Maastricht woonden, kwamen we wekelijks samen om te bidden. Dat wekelijkse rustpunt bracht ons dichterbij God en sterkte onze band.

Anita van Esch, op jouw steun kon ik altijd rekenen. We hebben er samen heel wat fietstochtjes naar Wolder opzitten. Fijn dat jij na het vertrek van Natasja mijn gebedspartner werd.

Gerda Wagenaar, we kennen elkaar van het VWO en van onze studie in Groningen. Tijdens de wandelvakanties en weekendjes daarna, leerden we elkaar nog beter kennen. Ik heb altijd veel aan de gesprekken met jou gehad. 
Natasja en Gerda, fijn dat jullie me als paranimfen willen bijstaan op de dag van mijn promotie!

En mijn familie, die mijn leven lang al zo belangrijk voor mij is. Gertjo \& Joanne, Jan-Henk \& Maria, Jofina \& Ard en Egbert, wat hebben we een hechte band en een lol met elkaar! Papa en mama, jullie steun en betrokkenheid waren er voortdurend. Dank voor alles wat ik van jullie geleerd heb en voor hoe jullie me steeds gestimuleerd hebben om mijn gaven en talenten te gebruiken en te ontwikkelen zoals dat bij me past.

Mijn hemelse Vader, dank voor elke nieuwe dag, voor hoe $U$ mij gemaakt hebt en dank dat $U$ er altijd bent!

Dineke Tigelaar, september 2005 
- 


\section{Content}

Dankwoord (Acknowledgements in Dutch)

2 The development and validation of a framework for teaching competencies in higher education

Published in Higher Education, 48, 253-268, 2004. E.H. Tigelaar, D.H.J.M.

Dolmans, H.A.P. Wolfhagen, and C.P.M. Van der Vleuten

3 Using a conceptual framework and the opinions of portfolio experts to develop a teaching portfolio prototype

Published in Studies in Educational Evaluation, 30(4), 305-321, 2004.

E.H. Tigelaar, D.H.J.M. Dolmans, H.A.P. Wolfhagen, and C.P.M. Van der Vleuten

$4 \quad$ Portfolio as a tool to stimulate teachers' reflections

Accepted for publication in Medical Teacher. E.H. Tigelaar, D.H.J.M. Dolmans, W.S. de Grave, H.A.P. Wolfhagen, and C.P.M. Van der Vleuten

Participants ${ }^{\prime}$ opinions about the usefulness of a teaching portfolio

Accepted for publication in Medical Education. E.H. Tigelaar, D.H.J.M.

Dolmans, W.S. de Grave, H.A.P. Wolfhagen, and C.P.M. Van der Vleuten

Quality issues in judging portfolios: implications for organizing teaching portfolio assessment procedures

Published in Studies in Higher Education, 30(5), 595-610. E.H. Tigelaar, D.H.J.M.

Dolmans, H.A.P. Wolfhagen, and C.P.M. Van der Vleuten

$7 \quad$ General discussion

Summary

Nederlandse samenvatting

Publications

Curriculum Vitae 


\section{1}

\section{Introduction}

The subject of this thesis is the design and evaluation of a teaching portfolio that can be used for formative and summative assessment of teachers in higher education. We defined the theoretical underpinnings of such a portfolio and designed, tested and adjusted it in an iterative process. The first chapter deals with the background of the study: the problem definition, the context of the study, and the nature of the study. We conclude this chapter by presenting an outline of the studies that together form this thesis.

\section{Background to the study}

\section{Constructivist theories of learning and implications for views of teaching}

Modern society is characterised by rapid changes and an ongoing increase in knowledge (Birenbaum, 2003; Atkins, 1995; Tynjälä, 1999). In this 'age of knowledge', those who wish to participate and function fully and effectively in today's society must be lifelong learners. This places new and high demands on higher education. Higher education is expected to equip students with the required competencies by stimulating critical thinking, reflection, knowledge creation, the ability to integrate theoretical and practical knowledge and the capacity to learn from practical experiences (Atkins, 1995; Tynjälä, 1999). These requirements are grounded in constructivist theories about learning, which are highly influential in higher education today (Birenbaum, 2003; Tynjälä, 1999). Although different perspectives can be discerned in these theories, they have certain concepts in common (Birenbaum, 2003). An important notion in theories about constructivist learning is that learners actively construct their own knowledge by interpreting new information on the basis of what they already know. Reflection, participation and learner control are crucial in this process. Another important feature of constructivism is the emphasis on the social, interactive and contextual nature of learning. Learning is also seen as being influenced by motivation, affect and cognitive styles. Finally, learning is a labour intensive process requiring strenuous effort and guided practice. It is recognised that teachers have a crucial role as facilitators of students' learning (Biggs, 1999). 
Constructivist learning theories not only apply to student learning but are equally applicable to teachers and their learning, with teachers being viewed as learners who are actively constructing their knowledge by interpreting events in teaching practice on the basis of their existing knowledge, beliefs and dispositions (Eraut, 1994; Feiman-Nemser \& Remillard, 1996; Putnam \& Borko, 1997). It is recognised that teachers, like other professionals, need the capacity for continuous learning from their experiences (Eraut, 1994). Teachers' professional development and learning are viewed as unique dynamic processes that continue throughout their teaching career and in which a vital part is played by collaboration and dialogue with colleagues (Cochran-Smith \& Lytle, 1999). These views on learning and teaching have implications for faculty development activities, such as critical reflection on teaching practice and participation in social interactions to facilitate the development of new insights and understanding about teaching and learning (Fulton \& Licklider, 1998).

\section{Developments in assessment}

The current views on learning and teaching have gradually altered the prevailing views with regard to the function and methods of assessment. This change is often referred to as an evolution from testing to assessment. From the assessment perspective, assessment is viewed as a tool for the enhancement of instruction and learning (Dochy \& McDowell, 1997). We will elucidate the evolution from testing to assessment by describing the changes in perspective for six dimensions of teaching (figure 1.1) (Segers, 2004).

\begin{tabular}{|c|c|c|}
\hline & Testing & Assessment \\
\hline \multirow[t]{2}{*}{ Authenticity } & & $\longrightarrow$ \\
\hline & Decontextualised, atomic & Contextualised, coherent \\
\hline \multirow{2}{*}{\multicolumn{3}{|c|}{$\begin{array}{l}\text { Number of } \\
\text { Measurement instruments }\end{array}$}} \\
\hline & - & \\
\hline & Single & Multiple \\
\hline \multirow[t]{2}{*}{ Levels of competency } & & \\
\hline & Low & High \\
\hline \multirow[t]{2}{*}{ Competency dimensions } & & \\
\hline & Few/Cogntitive & Multiple \\
\hline \multirow[t]{2}{*}{ Relation to the learning process } & & \\
\hline & Isolated & Integrated \\
\hline \multirow[t]{2}{*}{ Responsibility } & 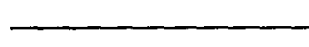 & $\longrightarrow$ \\
\hline & Teacher / examiner & Learner / assessee \\
\hline
\end{tabular}

Figure 1.1: Assessment characteristics and the differences between testing and assessment procedures as derived from Segers, 2004, p. 9 
The first dimension refers to the change from decontextualised, atomic tests to authentic, contextualized assessment modes. Assessment should be conducted in relevant contexts, which is in line with the constructivist view that learning is context related (Birenbaum, 2003). The second dimension is related to current views on learning and professional development which emphasise lifelong learning (Atkins, 1995; Eraut, 1994). Whereas it used to be customary to perform one measurement to test a learner's competence, the new approach involves the capturing of competency profiles by multiple methods and measurements over a prolonged period of time. The third dimension concerns the level of competency that is assessed. Traditionally, tests focused primarily on the reproduction of knowledge. Today, assessment latches onto a higher level of competency. It has become a process involving various methods that measure complex skills as well as the ability to construct meaning (Dochy, Segers, \& Sluijsmans, 1999). The fourth dimension refers to a focus on multidimensional competencies including affect and social styles as opposed to the traditional exclusive focus on cognitive skills. The fifth dimension stresses the interconnectedness of assessment and the learning process. Not only the outcomes of learning but the process of learning also should be assessed in an integrated manner. This means that formative and summative assessment must be carefully balanced in order to stimulate learning (Dierick \& Dochy, 2001). Feedback is a crucial factor in this process. Finally, the sixth dimension relates to the responsibility for assessment, with a transition from examiners' control to involvement of the assessee in learning processes and assessments. This is in line with the call for learner participation in current views on learning (Birenbaum, 2003).

As a result of the evolution from testing to assessment, the integration of assessment, instruction and learning has become a key notion. In order to promote this integration, a high consistency between learning, instruction and assessment is required. This is often referred to as the principle of 'alignment' (Biggs, 1996). New modes of assessment include procedures involving methods like simulations, peer assessment, co-assessment, self-assessment and portfolios.

\section{Teaching portfolios}

Teaching portfolios are increasingly being used in teacher education (Bird, 1990; Zeichner \& Wray, 2001). A teaching portfolio contains samples of a teacher's work collected over a period of time across various contexts and accompanied by reflections (Wolf \& Dietz, 1998). Different purposes of teaching portfolios can be distinguished (Bird, 1990; Zeichner \& Wray, 2001). An important distinction is that between the formative purpose, which is to stimulate learning and professional development, and the summative purpose, where the portfolio is used as evidence to underpin decisions about certification and promotion (Edgerton, Hutchings, \& Quinlan, 1991; Seldin, 1991; Snyder, Lippincott, \& 
Bower, 1998). Portfolios fit well with constructivist views on learning, teaching and assessment, as they are intended to encourage reflective practice and teachers' professional growth by stimulating teachers to obtain more insight into their learning processes and helping them revisit their own knowledge and express it in personally meaningful ways (Freidus, 1998; Bird, 1990; Zeichner \& Wray, 2001). Moreover, no other method is equally capable of creating an authentic picture of the contexts and personal histories of individual teachers' teaching practice and of documenting the longitudinal unfolding of both teaching and learning (Wolf, 1991). Thus, portfolios are able to capture the full range of the complexities of teaching practice. Because a carefully compiled portfolio provides direct evidence of a teacher's knowledge and competencies, it can also be used as a tool for making decisions about faculty development and career planning.

\section{General problem definition}

Although portfolios have been conceptualised and implemented in a variety of ways (Zeichner \& Wray, 2001), the diversity of the above-mentioned uses of portfolios suggests that the instrument is suitable for both development and assessment purposes. Indeed, portfolios have been conceptualised as potentially valuable instruments for the integration of formative and summative functions, which is characteristic of the transition from testing to assessment (Dierick \& Dochy, 2001). However, most portfolios are designed as either a development or an assessment tool. It is a controversial issue whether these two functions can be combined in one portfolio procedure and how this should be done to achieve a constructive alignment of learning and assessment. When portfolios are used for summative and high stakes assessment, the quality of the assessment procedure, reliability in particular, is frequently considered to pose a serious problem (Davies \& LeMahieu, 2003; Wilkerson \& Lang, 2003).

In line with constructivist views of learning and the corresponding need for alignment of learning and assessment, we wanted to develop a procedure for a teaching portfolio that was suitable for both formative and summative purposes in higher education. The portfolio should give teachers insight into their learning processes that occur as they are teaching and at the same time it should provide an appropriate basis for promotion decisions, i.e. decisions about the feasibility of pursuing a career in teaching on the basis of actual teaching performance. These combined objectives place high demands on the quality of the portfolio procedure and the judgment methods. 
Thus, the definition of the general problem that we addressed in this thesis was: What form should a teaching portfolio take to be appropriate for both formative and summative purposes and how can the quality of such a portfolio be guaranteed?

We focused on the design and the evaluation of a portfolio procedure for experienced university teachers, because the quality of teaching has become a crucial concern at colleges and universities today (Biggs, 1999; Seldin, 1991). We explored the use of the portfolio with five experienced teachers and their personal coaches, all medical doctors working at Maastricht Medical School. The research can be characterised as an iterative process of designing and evaluating the portfolio and defining its theoretical foundations.

The problem definition that we addressed is not only theoretically relevant, it has also practical relevance, because of the need for sound methodological advice and heuristics for those who wish to design and develop high quality assessment procedures, like portfolios (Dierick \& Dochy, 2001). This thesis is thus primarily of importance for assessment designers. In addition, however, the answers to the questions that are addressed provide insight into how learning and assessment can be integrated. Because this is crucial for teachers' professional development, this thesis will also be of considerable interest to faculty developers.

\section{Nature of the research}

The research that we performed can be characterised as Design-Based Research. Design-Based Research has the dual goal of refining both theory and practice (Barab \& Squire, 2004; Collins, Joseph, \& Bielaczyc, 2004). Although Design Based Research recently received renewed attention in various special issues (Barab \& Squire (Eds.), 2004; Sandoval, W. \& Bell, P. (Eds.), 2004) the approach is not entirely new. Similar approaches were pursued earlier under the headings of 'developmental research' (Van den Akker, 1999) and 'design experiments' (Brown, 1992; Collins, 1992; Reeves, 2005). Typically, DesignBased Research is conducted within a natural, real life setting as an iterative process in which design interventions are constantly being linked with existing theory. In this process, principles are generated that guide the design, development and evaluation process of educational interventions, such as products, programmes, procedures, and materials. The aim is to both create a design that works in a complex social setting and to develop a profile or theory that characterises the design in practice. Usually, this kind of research involves a cyclic design and development process with phases like analysis, design, evaluation and revision (Van den Akker, 1999). These activities are iterated until a satisfying balance between ideals and practical realisation has been achieved. The analysis phase usually comprises a preliminary investigation of the theoretical background to the problem as well as the context. The design 
phase covers the planning of the design and the construction of the specifications of the intervention. Formative evaluation is a key activity in this kind of research because it provides the information that feeds the cyclic developmental process during the consecutive loops of a design and development trajectory (Van den Akker, 1999). On the basis of formative evaluations, the design is revised so as to adapt it better to the desired purposes.

Theoretical grounding and interaction with practitioners and experts are important considerations in Design-Based Research, because the focus is on the creation of effective and practical interventions that may lead to the resolution of problems in the real world. In actual design and development processes, various approaches can be distinguished, including the instrumental, communication, prototyping and artistic paradigm (Van den Akker, 1999). The research that is presented in this thesis draws on characteristics from both communication and prototyping approaches toward design and development processes. This implies that apart from the definition of the portfolio's theoretical underpinnings, stakeholders' opinions were important considerations in the design and development of the portfolio procedure. It also meant that the portfolio design, i.e. the prototype, was continually modified and updated in accordance with the research findings.

\section{Overview of the study}

A cyclic process of defining theoretical underpinnings and design and evaluation activities was the basis for the development of a portfolio procedure for both formative and summative teacher assessment. In Figure 1.2, we give an outline of the research that is presented in this thesis.

The research consisted of three phases: (1) Analysis \& Design; (2) Evaluation; and (3) Analysis \& Design. The first analysis and design phase is described in Chapters 2 and 3. Chapter 2 describes a design activity that was carried out prior to the actual design and development process of the teaching portfolio. The aim was to develop and validate a framework for teaching competencies in higher education, which could be used as a starting point for appraisal of teachers' performance in higher education. This framework was developed by means of a Delphi study in which educational experts were asked to answer the question: 'How important are the following teaching competencies in each domain for an experienced teacher in higher education?' Chapter 3 reports on the design process of a prototype for a teaching portfolio for teacher development and assessment purposes. This study was aimed at specifying the theoretical underpinnings of the teaching portfolio as well as at the development, on the basis of these underpinnings, of a proposal for a portfolio prototype that was suitable for formative and summative purposes. 


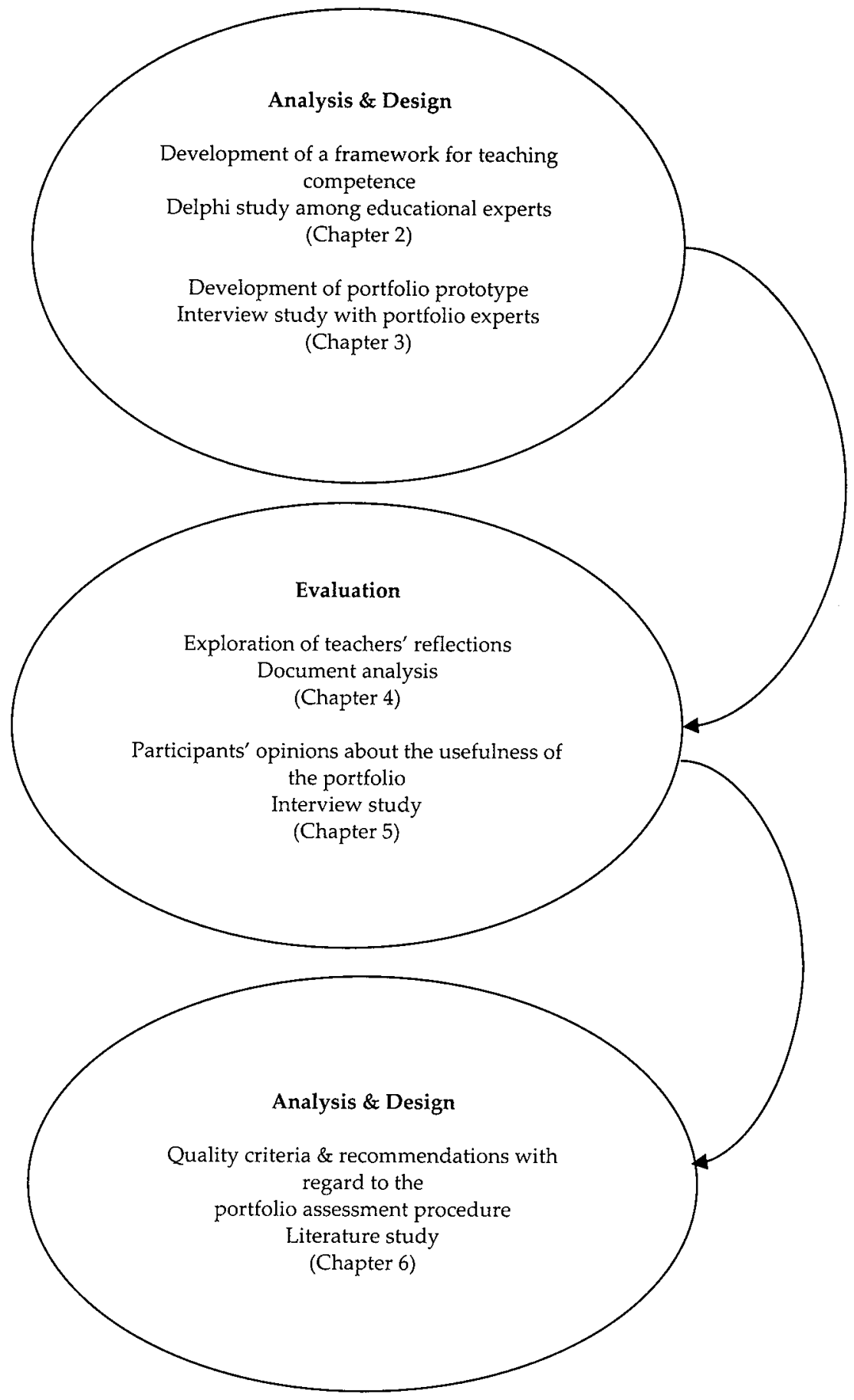

Figure 1.2. Overview of the study 
This prototype was tested against the opinions of portfolio experts after which modifications were made. The evaluation phase is addressed in Chapters 4 and 5. These studies investigated the effectiveness of the portfolio as an instrument for stimulating teachers' professional development. We explored the formative function of the portfolio in a small-scale study in order to specify and revise the design. The study described in Chapter 4 explored which aspects of teachers' professional work are for them subjects of reflection. We analysed portfolio assignments to identify illustrative examples of teachers' reflections on a variety of aspects of their functioning. Chapter 5 examined enabling and disabling factors in relation to the stimulation of teachers' professional development by the portfolio, particularly teachers' opinions about the portfolio's structure and social interactions as part of the portfolio process. We sought teachers' and their coaches' opinions about the benefits and the enabling and disabling factors within the portfolio structure and the related social interactions. We also inquired whether they thought the portfolio was a good instrument for fostering professional development and for summative decisions about prospects for a career in education. Chapter 6 addresses quality issues in relation to portfolio judgment from a theoretical perspective. The aim of this study was to determine how to guarantee the quality of a teaching portfolio procedure that is suitable for both formative and summative purposes. The study explored methods for judging teaching portfolios and appropriate quality criteria. On the basis of the arguments presented in this study, recommendations are made for the organisation of assessment procedures for teaching portfolios. Finally, in Chapter 7 , we return to the general problem definition and aims and we discuss what we have learned from our design and development efforts as well as the implications with regard to the theoretical underpinnings and the practical implementation of teaching portfolios.

\section{References}

Atkins, M. (1995). What should we be assessing. In P. Knight (Ed.), Assessment for learning in higher education (pp. 25-33). London: Kogan Page.

Barab, S., \& Squire, K. (Eds.). (2004). Design-Based Research: Clarifying the terms [Special issue]. The Journal of the Learning Sciences, 13(1).

Biggs, J. (1996). Enhancing teaching through constructive alignment. Higher Education, 32, 347-364.

Biggs, J. (1999). Teaching for quality learning at University. Buckingham: SRHE Open University Press.

Bird, T. (1990). The schoolteacher's portfolio: an essay on possibilities. In J. Millman \& L. E. DarlingHammond (Eds.), The new handbook of teacher evaluation. Assessing elementary and secondary schoolteachers (pp. 241-256). Newbury Park: CA: Corwin Press Inc.

Birenbaum, M. (2003). New insights into learning and teaching and their implications for assessment. In M. Segers, F. Dochy \& E. Cascallar (Eds.), Optimising new modes of assessment: in search of qualities and standards (pp. 13-36). Dordrecht/Boston/London. 
Brown, A. L. (1992). Design experiments: Theoretical and methodological challenges in creating complex interventions in classroom settings. Journal of the Learning Sciences, 2, 141-178.

Cochran-Smith, M., \& Lytle, S. L. (1999). Relationships of knowledge and practice: Teacher learning in communities. In A. Iran-Nejad \& C. D. E. Pearson (Eds.), Review of research in education (Vol. 24, pp. 249-305). Washington D.C.: American Educational Research Association.

Collins, A. (1992). Towards a design science in education. In E. Scanlon \& T. O'Shea (Eds.), New directions in educational technology (pp. 15-22). Berlin: Springer.

Collins, A., Joseph, D., \& Bielaczyc, K. (2004). Design research: theoretical and methodological issues. The Journal of the Learning Sciences, 13(1).

Davies, A., \& LeMahieu, P. (2003). Assessment for learning: Reconsidering portfolios and research evidence. In M. Segers, F. Dochy \& E. E. Cascallar (Eds.), Optimising new modes of assessment: In search of qualities and standards. Dordrecht/Boston/London: Kluwer Academic Publishers.

Dierick, S., \& Dochy, F. (2001). New lines in edumetrics: new forms of assessment lead to new assessment criteria. Studies in Educational Evaluation, 27, 307-329.

Dochy, F., Segers, M., \& Sluijsmans, D. (1999). The use of Self-, Peer and Co-assessment in Higher Education: a review. Studies in Higher Education, 24(3), 331-350.

Dochy, F. J. R. C., \& McDowell, L. (1997). Assessment as a tool for learning. Studies in Educational Evaluation, 67(23), 279-298.

Edgerton, R., Hutchings, P., \& Quinlan, K. (1991). The teaching portfolio: capturing the scholarship in teaching. Washington D.C.: AAHE.

Eraut, M. (1994). Developing professional knowledge and competence. London: The Falmer Press.

Feiman-Nemser, S., \& Remillard, J. (1996). Perspectives on learning to teach. In F. B. Murray (Ed.), The teacher educator's handbook: Building a knowledge base for the preparation of teachers (pp. 6391). San Francisco: Jossey Bass.

Freidus, H. (1998). Mentoring portfolio development. In N. Lyons (Ed.), With portfolio in hand: Validating the new teacher professionalism (pp. 51-68). New York, London: Teachers College Press.

Fulton, C., \& Licklider, B. L. (1998). Supporting faculty development in an era of change. In M. E. Kaplan (Ed.), To Improve the Academy (Vol. 17, pp. 51-66). Stillwater, OK: New Forums Press and the Professional and Organizational Development Network in Higher Education.

Putnam, R. T., \& Borko, H. (1997). Teacher learning: Implications of new views on cognition. In B. J. Biddle, T. L. Good \& I. F. Goodson (Eds.), International handbook of teachers and teaching (pp. 1223-1296). Boston: Kluwer.

Reeves, T. C. (2005). Design-Based Research for advancing educational technology. In M. Valcke, K. De Cock, D. Gombeir, R. Vanderlinde (Eds.) Meten en onderwijskundig onderzoek [Measurements and educational research]. Proceedings of the 32 Dutch-Flemish Educational Research Days, Gent, the Netherlands (pp. 33-39). Gent: Faculty of Educational Sciences.

Sandoval, W. \& Bell, P. (Eds.). (2004). Design-based research methods for studying learning in context [Special Issue]. Educational Psychologist, 39(4).

Segers, M. (2004). Assessment en leren als een twee-eenheid: Onderzoek naar de impact van assessment op leren. [The dyad of assessment and learning: a study of the imtpact of assessment on learning.] Inaugural address given at the acceptance of professorship in Pedagogics, Educational Sciences in particular, at Leiden University. Leiden: Leiden University. 
Seldin, P. (1991). The teaching portfolio: a practical guide to improved performance and promotion/tenure decisions. Bolton: MA: Anker.

Snyder, J., Lippincott, A., \& Bower, D. (1998). The inherent tensions in the multiple use of portfolios in teacher education. Teacher Education Quarterly, 25(1), 45-60.

Tynjälä, P. (1999). Towards experts knowledge? A comparison between a constructivist and a traditional learning environment in the university. International Journal of Educational Research, 31, 357-442.

Van den Akker, J. (1999). Principles and methods of development research. In J. Van den Akker, R. B. Branch, K. L. Gustafson, N. M. Nieveen \& T. Plomp (Eds.), Design approaches and tools in education and training (pp. 1-14). Dordrecht, The Netherlands: Kluwer.

Wilkerson, J. R., \& Lang, W. S. (2003). Portfolios, the pied piper of teacher certification assessments: legal and psychometric issues. Educational Policy Analysis Archives, 11(45) retrieved [Date] from http;//epaa.asu/epaa/v11n45/.

Wolf, D. (1991). The schoolteacher's portfolio: Issues in design, implementation, and evaluation. Phi Delta Kappan(October), 129-136.

Zeichner, K., \& Wray, S. (2001). The teaching portfolio in US teacher education programs: what we know and what we need to know. Teaching and Teacher Education, 17, 613-621. 


\section{2}

\section{The development and validation of a framework for teaching competencies in higher education ${ }^{1}$}

Abstract. In higher education, approaches to teaching are becoming more student-centered, which demands other teaching competencies. Therefore, it is necessary to have an adequate framework of teaching competencies that can be used for evaluation purposes. The weaknesses of the existing frameworks are that they do not pay attention to the person as teacher, they are too narrowly defined, they are not validated and they are not adjusted to modern approaches to teaching.

The aim of this study was to develop and validate a framework of teaching competencies in higher education. Therefore, a framework for teaching competencies was constructed containing the following domains: The Person as teacher, Expert on content knowledge, Facilitator of learning processes, Organiser and Scholar/Lifelong learner. The framework was validated using a Delphi method. Educational experts $(\mathrm{N}=63)$ were asked: "How important are the following teaching competencies in each domain for an experienced teacher in higher education?" A confirmatory factor analysis was conducted to assess the adequacy of the domains.

After two rounds, the shift in ratings was minimal, so the results were stable. The response rate was $82 \%$. From the original list with 134 items, 30 items were omitted because many experts failed to respond to them. The experts reached consensus on 61 out of the resulting 104 items (59\%). A confirmatory factor analysis on the three best scoring items in each domain confirmed the model. A framework of teaching competencies was developed and validated that can be used as a starting point for teacher evaluation in higher education.

Keywords: Delphi method, Student-centered approaches to teaching, Teaching competencies

1 This chapter has been published as: Tigelaar, E.H., Dolmans, D.H.J.M., Wolfhagen, H.A.P., \& Van der Vleuten, C.P.M. (2004). The development and validation of a framework for teaching competencies in higher education. Higher Education, 48, 253-268. 


\section{Introduction}

Recent theories on teaching and assessment reveal that teaching is a complex activity that is shaped by the teaching context (Darling-Hammond, 2000; Trigwell, 2001). Moreover, changing visions on student learning and the teacher role require that teachers are continuously developing themselves professionally (Putnam \& Borko, 1997). Teaching competency frameworks can be useful for teachers to set their professional learning goals. However, these frameworks should give room to differentiated teacher profiles and should not only be focused on teacher behavior (Uhlenbeck, Verloop, \& Beijaard, 2002). Moreover, they should be appropriate for contemporary teaching approaches.

In these modern approaches to teaching, one distinction is very important. This is the distinction between the teacher-centered orientation and the studentcentered orientation to teaching (Kember, 1997). The more active a student is in the learning situation, the more student-centered the teaching orientation is. Samuelowicz \& Bain (2001) describe seven orientations to teaching and learning in which teaching becomes gradually more student-centered. These orientations can be seen as a continuum. In the first orientation, which is called imparting information, the teacher is a lecturer that passes on knowledge. In the final orientation, which is called encouraging knowledge creation, the teacher stimulates students to build original knowledge. In the student-centered orientations, the student must participate actively in the learning process and teachers have to take the students' perspective (Ramsden, 1992). Trigwell \& Prosser (1996) showed that the use of teaching strategies matches with the intention teachers have for their teaching. Teachers who conceive teaching as transmitting information to students approach their teaching in a teacherfocused manner. On the other hand, teachers who regard learning as developing and changing students' conceptions, conceive of teaching in terms of helping students to develop and change their conceptions and approach their teaching in a student-focused way (Trigwell, Prosser, \& Waterhouse, 1999). Moreover, there appears to be a positive relation between student-focused teaching and students' learning outcomes. Martin, Prosser, Trigwell, Ramsden, \& Benjamin (2000) added to these findings that there is a clear relationship between the teacher's intended objects of study and their intended approaches to teaching. Teachers who conceive the object of study in terms of 'knowledge as given' intend to adopt more teacher-focused approaches to teaching. Teachers who conceive the object of study in terms of 'knowledge as being constructed' intend to adopt more student-focused approaches to teaching. Moreover, the teaching environment shapes a teacher's approach to teaching by its curriculum design and institutional ethos, as well as the nature of the students (Ramsden, 1992; Kember \& Kwan, 2002).

The shift from focus on the teacher to focus on the student originates from ideas in constructivism (Ertmer \& Newby, 1993). A central tenet in 
constructivist approaches to learning is the active construction of knowledge by the learner. The student is seen as an active, self-regulating learner, who creates meaning from his or her own experiences in a meaningful way. The teacher role is to stimulate the construction of powerful knowledge, rather than to explicitly provide knowledge and information (Harris \& Alexander, 1998). This teacher role is different from the teacher role in traditional, teacher-centered education. In more student-focused approaches to teaching, different teaching competencies are needed. Over the last few decades, the constructivist orientation to teaching has become very important in higher education. Therefore, it is necessary to investigate what teaching competencies are required in modern, more student-centered higher education teaching contexts. A framework of teaching competencies adjusted to current, more studentcentered education environments can be useful as a starting point for evaluation purposes and for teachers to set professional learning goals.

In this study, teaching competencies are defined as follows:

Teaching competencies are an integrated set of personal characteristics, knowledge, skills and attitudes that are needed for effective performance in various teaching contexts. (This definition is based on several definitions mentioned by Bos, 1998; Stoof, Martens, Van Merriënboer \& Bastiaens, 2002). According to this definition, teaching competencies are integrated and should be viewed as a whole repertoire a teacher has at his or her disposal. The teaching context is important; that is, teaching competencies must be viewed in the light of the various contexts in which teaching takes place.

The purpose of this study is to develop and validate a framework for teaching competencies in higher education. This framework can be used as a starting point for teacher evaluation in higher education. Several frameworks of teaching competencies have already been defined for higher education. In the United States of America, the National Board for Professional Teaching Standards and the Committee on Promoting and Evaluating Teaching Effectiveness (PETE) have exerted considerable effort into defining teaching competencies. In the Netherlands, The Association of Universities in the Netherlands, VSNU (1996) has made a framework that is specified to higher education. The Executive Board of the Utrecht University, (1995) and The Association for Teacher Educators in the Netherlands, VELON (1999) have worked on defining teaching competencies in higher education in a more detailed way. Other frameworks in the Netherlands focus on primary and secondary education (Beijaard \& Uhlenbeck, 2001, Dietze, Jansma, \& Riezebos, 2000, Moltmaker \& Meulenkamp, 2000, Twisk, Daniels, \& Bolweg, 1999).

Common elements in most frameworks are: competencies on content knowledge, didactic competencies (pedagogical methods and presentation skills, guidance and advising skills, design of curriculum and course material), organisational competencies, and scientific competencies (lifelong learning and reflection). Key principles of effective teaching (Ramsden, 1992) such as interest 
and explanation, concern and respect for students and student learning, appropriate assessment and feedback, clear goals and intellectual challenge, independence, control and active engagement and learning from students can be found in these frameworks. However, many of the existing frameworks are not adjusted to modern approaches to teaching. Moreover, critics of existing frameworks with teaching competencies argue that these lists are too detailed and too prescriptive (Korthagen, 2001). A good teacher cannot be described in terms of isolated abilities or a long list of items as is outlined in the definition of teaching competencies formulated above. In addition, another weak point of the existing frameworks is that they do not pay attention to the fact that aspects of a teacher's personality play an important role in being a good teacher (Korthagen, 2001). Aspects of a teacher's personality that are important for effective teaching are the teacher's professional identity (how he or she views himself or herself as a teacher), his or her beliefs about teaching and the teacher's involvement in teaching. Korthagen (2001) mentions some personal characteristics that are important for teachers such as empathy, and the ability to regulate frustration and impatience. Lowyck (1994) also stresses that it is not the teaching behaviour in itself but the teacher's personality that is the paramount indicator for effectiveness. Another weak point of the existing frameworks is that they are not validated.

These critics of the existing frameworks have implications for designing a new framework. A useful framework should be adjusted to modern approaches to teaching and it should be broadly defined. Moreover, it should contain a domain with aspects of a teacher's personality that are conducive to being a good teacher. Finally, it is important to validate the content of a framework for teaching competencies through involvement of educational experts. Educational experts, who have knowledge of important aspects of teaching from their theoretical and practical experience, are a useful source of information to develop and validate the framework. Therefore, the Delphimethod seems to be a useful method: In a Delphi-procedure, a panel of experts rates a questionnaire on different rounds until consensus or stability in panel member's responses is reached (Williams \& Webb, 1994). Smith \& Simpson, (1995) also used a Delphi-method to develop and validate a framework of teaching competencies in higher education.

The Delphi technique has several advantages that make it useful. First, it is an efficient method to obtain information from educational experts and to reach consensus, for after each round, the panellists are confronted with their own ratings in comparison with the mean score and standard deviation on each item. Furthermore, the bias of dominant views within group discussions is avoided; for members can individually consider what teaching competencies they find important. And finally, compared to other techniques that can be used to analyse required competencies, for example the Critical Incident Technique, Delphi has the advantage that opinions and ideas are crystallised and not only 
based on critical tasks in which only conspicuous elements of teaching that are important can be taken into account (Murry \& Hammons, 1995; Clayton, 1997; Williams \& Webb, 1994).

\section{Method}

\section{Subjects}

For the Delphi study, educational experts were selected who work in higher education. These experts were selected because they are involved in teaching as policy maker, trainer or investigator. All these experts have ideas on what teaching competencies are required in higher education from different perspectives, because they represent several disciplines and institutions. Furthermore, the experts that were selected have at least five years experience in higher education. On the basis of these criteria, a varied and knowledgeable panel was composed, which resulted in a list of 74 experts. These experts received a letter to invite them to participate in the Delphi study. Sixty-three out of the 74 selected educational experts agreed to participate (85\%).

\section{Materials}

For the design of the proposed framework, it was decided to make use of existing frameworks. We used frameworks from the Netherlands, for the purpose of this study was to develop and validate a framework of teaching competencies that will be used for the teacher evaluation in student-centred higher education in the Netherlands. Existing frameworks from Beijaard \& Uhlenbeck (2001), The Executive Board of the Utrecht University, (1995), Dietze, Jansma, \& Riezebos, (2000), Moltmaker \& Meulenkamp (2000), Smith \& Simpson (1995), Twisk, Daniels, \& Bolweg (1999), VELON (1999), VSNU (1996) were studied, but primarily the frameworks of The Executive Board of the Utrecht University, (1995), VELON (1999) and VSNU (1996) have been used in this study because they were specified to higher education. The competency descriptions were taken from these frameworks and adjusted to modern approaches to teaching. In this study, a framework is proposed with the following domains: the person as teacher, the teacher as expert on content knowledge, the teacher as facilitator of learning processes, the teacher as organiser and the teacher as scholar/lifelong learner. The domain 'the person as teacher' was added as a new domain. The items in this domain are based on the ideas of Korthagen (2001). In addition, operationalisations from Moltmaker \& Meulenkamp (2000) and Smith \& Simpson (1995) have been used in this domain. The first domain is called the person as teacher since its focus is on personal characteristics that make him or her a good teacher (and not the teacher as a person because the personal life of a teacher is not included). The 
domain 'the teacher as expert on content knowledge' does not seem to be in line with student-centred education on the first sight, but taking a student's perspective does not imply that content knowledge is unimportant. The items in this domain focus on how a teacher uses his or her content-knowledge to stimulate student learning and takes the students' perspective into account. The third domain, 'the teacher as facilitator of learning processes', consists of three subcategories: the teacher as designer, counsellor and evaluator of education. The subdomain 'the teacher as designer' comprises items that focus on designing educational materials that activate and stimulate students to gradually learn independently. The subdomain 'the teacher as counsellor' incorporates items that focus on providing students with advice, feedback, etc. The subdomain 'the teacher as evaluator' includes not only items that focus on student evaluation, but also items that focus on peer-evaluation of the teacher. The domain 'the teacher as organiser' includes items that focus on how a teacher collaborates with colleagues and organises the work. The domain 'the teacher as scholar/lifelong learner' comprises items that focus on a teacher's professional development and scientific skills.

A Delphi-questionnaire, which consisted of 134 items, was developed. Twenty items related to the person as teacher, 13 items to the teacher as an expert on content knowledge, a total of 65 items to the teacher as facilitator, 14 items to the teacher as organiser, and 22 items to the teacher as scholar/lifelong learner. The participating educational experts were asked to think of an experienced teacher in higher education who has a student-centred vision on education as described in the introduction section. For each domain, the experts were asked: "How important are the following teaching competencies in this domain? They had to rate each item on a Likert scale ranging from totally unimportant $(=1)$ to very important $(=5)$. They were also asked to edit or reword each statement they felt needed revision and to provide additional administration.

\section{Procedure}

First, a pilot was done in which three experts gave their judgement on the Delphi-questionnaire. On the basis of the findings from this pilot, the wording of some items was made unambiguous, to prevent misinterpretations.

All 63 out of the 74 selected educational experts who agreed to participate in the Delphi study received the round one questionnaire. They rated the items on a Likert-scale. Subsequently, the data were analysed and the second questionnaire was sent to 62 panel members who had responded to round one. In the second round, the questionnaire included the ratings of the individual panel member to each item in round one and the mean and standard deviation of all participants' responses in round one. Panel members were asked to rerate or confirm the original rating of each item. 


\section{Analysis}

In a Delphi study, panellists are confronted with the results after each round, until consensus or stability of results is reached. Before starting the Delphi study, stability or convergence was defined as occurring when there was minimal or no further shifting of panel responses from round to round. As a criterion of stability for mean scores, a shift of 20 percent or less after successive rounds was chosen, which is a shift of less than one on a scale of one to five. Consensus was defined as agreement between panellists on rating a particular item within a specific round. $75 \%$ was taken as a minimum percentage of agreement on any particular item (Murry \& Hammons, 1995). For calculating the consensus, the scores 1 and 2 were computed as (totally) unimportant, 3 as average, and 4 and 5 as (very) important. This implies that in this study, an item is viewed as (very) important when 75 percent of the educational experts rated this item with a score 4 or 5 .

A confirmatory factor analysis was carried out to assess the adequacy of the five factors underlying the items. For the confirmatory factor analysis, data were analysed at the item level. Only the top three in each domain were included, i.e., 15 items were included in the confirmatory factor analysis. The five domains were taken as factors. In total, all 51 experts that completed two rounds were involved in the confirmatory factor analysis. In the confirmatory factor model, as specified in this study, the first three top scores were assumed to be affected by the first factor, the next three by the second factor, et cetera. All factors were correlated. All 15 items were assumed to be affected by a unique factor (error in each variable), and no pairs of unique factors were correlated. The AMOS programme was used to determine whether the data confirmed this model (Arbuckle, 1997).

\section{Results}

The number of experts that agreed to participate in the Delphi study was 63 out of $74(85 \%)$. After round one, 62 completed questionnaires out of 63 were returned (99\%). The means and standard deviations of each item were computed. Fifty-one out of 62 experts returned the round two questionnaire $(82 \%)$. The results of round two were stable in accordance to the results of round one, i.e., the shift on the mean score on all items was less than $20 \%$. Therefore, it was not necessary to do a third round.

For the analysis, first, the items that five or more experts $(10 \%$ of the experts) had failed to respond to were removed (Table 2.1). 
Table 2.1. Number of items in each domain, number of items omitted because five ore more panellists failed to respond to them, and the percentage of items skipped in each domain.

\begin{tabular}{|c|c|c|c|}
\hline Domain & N items & $\mathrm{N}$ items omitted & Percentage of items omitted \\
\hline The person as teacher & 20 & 10 & $50 \%$ \\
\hline Expert on content knowledge & 13 & 3 & $23 \%$ \\
\hline \multicolumn{4}{|l|}{ Facilitator of learning processes } \\
\hline Developer & 20 & 1 & $5 \%$ \\
\hline Counsellor & 25 & 2 & $8 \%$ \\
\hline Evaluator & 20 & 2 & $10 \%$ \\
\hline Organiser & 14 & 4 & $29 \%$ \\
\hline Scholar/Lifelong learner & 22 & 8 & $37 \%$ \\
\hline Total & 134 & 30 & $22 \%$ \\
\hline
\end{tabular}

As can be seen in Table 2.1, 30 out of 134 items (22\%) were omitted because five or more panellists failed to respond to these items. In the domain the person as teacher, a high percentage of the items have been omitted (50\%). In the domain the teacher as organiser too, a high percentage $(29 \%)$ is omitted, as well as in the domain the teacher as scholar/lifelong learner (37\%).

The purpose of this study was to develop and validate a framework of teaching competencies in student-centred higher education by examining whether educational experts could reach consensus. Therefore, after omitting poorly rated items, the rest of the items were analysed to find out on which items the experts had reached agreement.

Before starting the Delphi study, consensus was defined as $75 \%$ agreement among the panellists' ratings. As can be seen in Table 2.2, if $75 \%$ is taken as a level of agreement, the experts reached consensus on 61 out of 104 items $(59 \%)$. All the items on which the educational experts reached consensus, were rated as important or very important (score 4 or 5 on scale 1-5). Table 2.2 also shows that the percentage of consensus on (very) important items is higher than $50 \%$ in all domains, except for the domain the teacher as organiser.

An overview of the most important items that were omitted together with the three highest scoring items in each domain on which the experts reached consensus, is presented in Table 2.3 . 
Table 2.2. Number of items, number of (very) important items* i.e. $75 \%$ of experts rated these items with 4 or 5 , percentage (very) important items

\begin{tabular}{lccc}
\hline Domain & $\mathbf{N}$ items & N (very) important items & Percentage \\
\hline The person as teacher & 10 & 6 & $60 \%$ \\
Expert on content knowledge & 10 & 9 & $90 \%$ \\
Facilitator of learning processes & & & \\
Developer & 19 & 10 & $53 \%$ \\
Counsellor & 23 & 15 & $65 \%$ \\
Evaluator & 18 & 9 & $50 \%$ \\
Organiser & 10 & 4 & $40 \%$ \\
Scholar/Lifelong learner & 14 & 11 & $79 \%$ \\
Total & 104 & 61 & $59 \%$ \\
\hline
\end{tabular}

For the person as teacher, the educational experts rated it most important that teachers are communicative, positive and respectful towards students. Items such as being empathically and having compassion with students were omitted in this domain. Using relevant information from specialist literature, thorough knowledge of subjects and knowledge of new developments in his or her subject were rated highest in the domain the teacher as expert on content knowledge. Items concerning estimating related visions to the subject matter and passing on important values that play a role in the discipline, were omitted. The educational experts rated placing the student in the centre, providing feedback and being capable of assessing students' learning results as most important in the domain the teacher as facilitator of learning processes. Items such as being capable of using audiovisual means and announcing examinations timely were omitted in this domain. For the teacher as organiser, the panellists found it most important that teachers are capable of cooperating with peers and being communicative in these contacts. Also contributing to the curriculum was given a high rating. Items concerning supervision of beginning teachers and time-management were omitted. The educational experts found reflection on teaching performance and being able to draw conclusions from that most important for the teacher as scholar/lifelong learner, as well as being open to change. Items concerning research activities were omitted in this domain. 
Table 2.3. Most important items that were omitted and (very) important items on which consensus was reached*i.e. $75 \%$ of experts rated these items with 4 or 5

\begin{tabular}{|c|c|c|}
\hline Domain & Omitted items & $\begin{array}{l}\text { (Very) important items on which } \\
\text { consensus was reached }\end{array}$ \\
\hline Person as teacher & $\begin{array}{l}\text { Is emphatically } \\
\text { Is perseverenced } \\
\text { Has compassion with students }\end{array}$ & $\begin{array}{l}\text { Is skilled at communicating } \\
\text { Has a positive attitude for students } \\
\text { Exhibits respect for all students }\end{array}$ \\
\hline $\begin{array}{l}\text { Expert on content } \\
\text { knowledge }\end{array}$ & $\begin{array}{l}\text { Is capable of estimating visions } \\
\text { that are related to his subject } \\
\text { matter } \\
\text { Has knowledge of the whole } \\
\text { educational supply in his subject } \\
\text { Passes on important values that } \\
\text { play a role in the discipline/the } \\
\text { profession }\end{array}$ & $\begin{array}{l}\text { Is capable of using relevant } \\
\text { information from specialist literature } \\
\text { for his or her own teaching } \\
\text { - Has thorough knowledge of his or } \\
\text { her subjects } \\
\text { - Has knowledge of new developments } \\
\text { in his or her subject }\end{array}$ \\
\hline \multicolumn{3}{|l|}{$\begin{array}{l}\text { Facilitator of learning } \\
\text { processes }\end{array}$} \\
\hline Developer & $\begin{array}{l}\text { Takes the line of the curriculum } \\
\text { into account when structuring } \\
\text { education }\end{array}$ & $\begin{array}{l}\text { Places the student in the centre when } \\
\text { designing educational material } \\
\text { Is capable of designing activating } \\
\text { educational materials } \\
\text {, Is capable of building education in } \\
\text { such a way that students gradually } \\
\text { learn to learn in a self directed } \\
\text { manner }\end{array}$ \\
\hline Counsellor & $\begin{array}{l}\text { Provides a learning environment } \\
\text { in which all students can come to } \\
\text { optimal learning results } \\
\text { Is capable of supporting the } \\
\text { learning process by adequate } \\
\text { audiovisual means }\end{array}$ & $\begin{array}{l}\text { Is capable of giving feedback } \\
\text { Places the student in the centre in his } \\
\text { or her teaching } \\
\text {. Is capable of activating students }\end{array}$ \\
\hline Evaluator & $\begin{array}{l}\text { Is capable of putting differences } \\
\text { between individual students in the } \\
\text { perspective of the long-term } \\
\text { learning process of the student } \\
\text { Announces examination- } \\
\text { arrangements timely }\end{array}$ & $\begin{array}{l}\text { Is capable of assessing students } \\
\text { learning results } \\
\text { Is capable to re-adjust his or her } \\
\text { teaching practice on the basis of } \\
\text { evaluations } \\
\text { Is capable of designing test that are } \\
\text { appropriate for the desired learning } \\
\text { results }\end{array}$ \\
\hline
\end{tabular}


Table 2.3. (Cont.)

\begin{tabular}{|c|c|c|}
\hline$\overline{\text { Domain }}$ & Omitted items & $\begin{array}{l}\text { (Very) important items on which } \\
\text { consensus was reached }\end{array}$ \\
\hline Organiser & $\begin{array}{l}\text { Is capable of supervising student- } \\
\text { assistants and Ph-D-students in } \\
\text { their teaching tasks } \\
\text { Is capable of time-management } \\
\text { Contributes to development of the } \\
\text { organisation }\end{array}$ & $\begin{array}{l}\text { Is capable of cooperating with } \\
\text { colleagues } \\
\text { Is communicative when cooperating } \\
\text { with colleagues } \\
\text { Is capable of contributing to the } \\
\text { curriculum }\end{array}$ \\
\hline Scholar/lifelong learne & $\begin{array}{l}\text { Is interested in national and } \\
\text { international curriculum } \\
\text { developments } \\
\text { Is willing of and capable to } \\
\text { participate in research activities } \\
\text { Deals in an honest way with } \\
\text { matters of the discipline }\end{array}$ & $\begin{array}{l}\text { Is capable of reflecting on his or her } \\
\text { teaching performance } \\
\text { Is capable of drawing conclusions } \\
\text { from reflection on his or her teaching } \\
\text { performance } \\
\text {, Is open to innovations }\end{array}$ \\
\hline
\end{tabular}

A confirmatory factor analysis was conducted to assess the adequacy of the five factors underlying the 15 items that were scored highest within each domain. A confirmatory factor model is assumed to fit the data if three conditions are met: (1) The chi-square divided by the degrees of freedom should be lower than 2 , a p-value that differs from zero; (2) the root mean square residual should be lower than .07; and (3) the goodness-of-fit-index and the adjusted goodness-offit-index, which takes the number of degrees of freedom into account, should be higher than .80 (Saris \& Stronkhorst, 1984). The model as formulated initially did not fit. The output indicated that removing one item in the domain the teacher as scholar/lifelong learner would result in improvement of the fit of the model. Therefore, in order to improve the fit of the model, the item "has a professional attitude" was replaced by the item "is open to innovations", which was the next highest scoring item within the same domain. After replacing this item, the following results were found (also presented in Table 2.4): chi-square $[80 \mathrm{df}]=136.32, p=.002$, a root mean square residual of .069 , a goodness-of-fit index of .76, and adjusted goodness-of-fit index of .65. Compared to the three conditions described above, all conditions are met, except the third condition: the goodness-of-fit index and the adjusted goodness-of-fit index. Although these indices are not .80, they are very close to it (at least .65). In general the results of the confirmatory factor analysis indicate that the five-factor model fitted the data reasonably well, since two out of three conditions satisfied for the five-factor model. 
Table 2.4. Model fit of the top three on each factor, number of panellists $(\mathrm{N})$, Chi-square, degrees of freedom (df), significance level (p-value), chi-square divided by degrees of freedom (Cmin/df), root mean square residual (RMSR), goodness of fit index (GFI) and adjusted goodness of fit index (AGFI). The p-value should differ from zero.

\begin{tabular}{llllllll}
\hline $\mathbf{N}$ & Chi-square & Df & $\mathbf{p}$ & Cmin/df & RMSR & GFI & AGFI \\
\hline 51 & 136.32 & 80 & 0.002 & 1.7 & 0.069 & 0.76 & 0.65 \\
\hline
\end{tabular}

\section{Conclusion and discussion}

The aim of this study was to develop and validate a framework of teaching competencies in student-centered higher education. The Delphi method was used to find out whether educational experts could reach consensus on important teaching competencies. After two rounds, the results were stable. The items that five or more panellists out of 51 failed to respond to were omitted. Then we found that the experts had reached consensus on 61 out of 104 items, taking $75 \%$ as a level of consensus. In general, after omitting poorly rated items, the educational experts reached consensus on $59 \%$ of the items. In each domain, consensus was reached on more than $50 \%$ of the items, except for the domain the teacher as organiser, in which the level of consensus was $40 \%$. Moreover, a confirmatory factor analysis on the three best scoring items in each domain showed a reasonable fit, which indicates that the model was confirmed.

One of the requirements for a new framework of teaching competencies was that competencies should be broadly defined to give room to differentiated teacher profiles (Uhlenbeck et al., 2002; Korthagen, 2001). We believe we have met this condition, for the results indicate that the items that are broadly defined are rated as more important than the more detailed items. Moreover, the items that were omitted were typically defined in a more detailed way.

Another requirement for a new framework was a domain with aspects of a teacher's personality that are conductive for effective teaching (Korthagen, 2001). This condition was partly met. The results indicate that in the domain the person as teacher, $50 \%$ of the items had to be omitted because five or more panellists failed to respond to them. This might be explained by the fact that the domain the person as teacher is a new domain and the items in this domain could not be taken from other frameworks. The items that were omitted in this domain, such as being empathically and having compassion with students, might have been to vague to the experts for these items represent more deeply embedded aspects of a teacher's personality. The items on which the experts reached consensus in this domain, concerning a positive attitude for students and exhibiting respect, represent mainly one aspect of a teacher's personality that is important for effective teaching as mentioned by Korthagen (2001), which is a teacher's involvement in teaching. The other two aspects, a teacher's beliefs about teaching and how a teacher views himself or herself as a teacher, 
are not yet fully represented in the developed framework. Therefore, the domain person as teacher needs to be developed further and should be more focused on a teacher's intention for teaching (Trigwell \& Prosser, 1996) and his or her beliefs about knowledge (Martin, et al., 2000).

Another requirement for a new framework of teaching competencies was that it should be appropriate for more student-focused approaches to teaching. The results indicate that this requirement was reasonably met. The items in the domain the person as teacher represent a teacher's involvement in teaching that is focused on having a positive and respectful attitude for students. In the domain the teacher as expert on content knowledge, an item concerning passing on important values that play a role in the discipline is omitted, which represents a 'knowledge as fixed' conception of objects of study. In contrast, the experts reached consensus on items that show a more 'knowledge as constructed' conception of objects of study, such as items concerning knowledge of new developments in the subject. This is in line with research that has shown a clear relationship with conceiving 'knowledge as constructed' and adopting a more student-focused approach to teaching (Martin, et al., 2000). In the domain the teacher as facilitator of learning processes, very few items were omitted, which indicates that this domain is very important for student-focused approaches to teaching. The items on which the experts reached consensus in this domain, such as designing activating materials, building education in such a way that students gradually learn to learn in a self directed manner, providing feedback and designing tests that are appropriate for the desired learning results, are all in line with constructivist approaches to teaching in which the student is seen as an active, self regulated learner (Ertmer \& Newby, 1993; Harris \& Alexander, 1998). In the domain the teacher as organiser, $37 \%$ of the items had to be omitted. This finding might be explained by the fact that the teaching role as organiser is not familiar to all teachers in higher education. However, the fact that the experts reached consensus on items concerning cooperation with colleagues, indicates that the organiser role is mainly associated with contacts with peer-teachers. This is in line with recent theories about teachers' professional development, in which cooperation with peers is very important (Putnam \& Borko, 1997). Finally, in the domain the teacher as scholar/lifelong learner, many items are omitted (29\%). This might be explained by the fact that having scientific skills does not matter to all teachers in higher education. Nevertheless, the experts reached consensus on items concerning reflection skills and being open to innovations, which is corresponding to the need of continuous professional development for teachers in modern, more student-centred teaching environments (Putnam \& Borko, 1997). In sum, it can be concluded that the requirement for the new framework of teaching competencies concerning its appropriateness for more student-focused approaches to teaching was reasonably met. However, it is not only the items in itself that makes the developed framework specific for student-focused 
approaches to teaching. The nature of a teacher's performance also determines to what degree his or her teaching approach is student-focused (Samuelowicz \& Bain, 2001; Trigwell, 2001).

It should be acknowledged that the Delphi technique as adjusted in this study, has some limitations. Firstly, some general comments regarding the questionnaire can be made. Many items were rated with 4 or 5, which could indicate that all items in the original list are important. This could mean that it was difficult for the educational experts to discriminate between the items. Moreover, it was difficult to do justice to the definition of teaching competencies as formulated in the introduction section. The integration of personal characteristics, knowledge, skills and attitudes was problematic. However, the results indicate that in most domains, the items that are more integrated and broadly defined, are rated as more important than the more detailed items, which makes them useful as a starting point for teacher evaluation. Secondly, some comments concerning the selection of experts can be made. Although several experts were selected, it was difficult to make a meaningful distinction in the kind of experts that were selected because most of them fulfil several roles. For example, an educational expert can be both a policy maker and a practitioner of teaching. However, the experts represent different perspectives on teaching such as policy making, teacher training and research on teaching. Moreover, they represent several institutions. Thirdly, there is no evidence yet that the results of this Delphi method are reliable, that is, there is no evidence that the same results would have been achieved with a different panel that had been selected using the same criteria. Therefore, further validation of the framework with a different panel using the same criteria is needed.

Finally, as the validation process is not yet completed, the developed framework should be field-tested. Therefore, in future research, the developed framework will be piloted as a starting point for teacher evaluation. The items in the developed framework, which are broadly defined, will be presented to less experienced teachers to specify their own learning goals. Moreover, since the teaching environment is important in shaping a teacher's approach to teaching (Ramsden, 1992; Kember \& Kwan, 2002), the developed framework will be piloted in environments that provide suitable conditions for studentfocused approaches to teaching. 


\section{References}

Arbuckle, J.L. (1997). Amos users' guide. Chicago: IL Small Waters Corporation.

Beijaard, D., \& Uhlenbeck, A. M. (2001). Het formuleren van docentcompetenties: werkwijze en resultaten. [Formulating teacher competencies: procedure and results]. VELON Tijdschrift voor lerarenopleiders, 22(2), 26-33.

Bos, E. S. (1998). Competentie: verheldering van een begrip [Competence: clarifying a concept]. (Otec Report 98/RO1). Heerlen: Open Universiteit Nederland (Onderwijstechnologisch expertisecentrum).

Clayton, M. J. (1997). Delphi: a technique to harness expert opinion for critical decision-making tasks in education. Educational psychology, 17(4), 373-386.

Darling-Hammond, L., \& Snyder, J. (2000). Authentic assessment of teaching in context. Teaching and Teacher Education, 16, 523-545.

Dietze, A., Jansma, F., \& Riezebos, A. (2000). Een kijkkader voor competenties voor de tweedegraads lerarenopleidingen. [A framework of competencies for secondary grade teacher education]. Programma Management Educatief Partnerschap.

Ertmer, P.A. \& Newby T.J. (1993). Behaviorism, cognitivism, constructivism: Comparing critical features from an instructional design perspective. Performance Improvement Quarterly, 6, 4, 50-72.

Executive Board of the Utrecht University. (1995). Doceren aan de universiteit: basiskwalificatie. [University teaching: basic qualification]. Utrecht: Universiteit Utrecht.

Harris, K. R., \& Alexander, P. A. (1998). Integrated, constructivist education: challenge and reality. Educational Psychology Review, 10(2), 115-127.

Kember, D. (1997). A reconceptualisation of the research into university academics' conceptions of teaching. Learning and Instruction, 7(3), 255-275.

Kember, D., \& Kwan, K. (2002). Lecturers' approaches to teaching and their relationship to conceptions of good teaching. In N. Hativa \& P. Goodyear (Eds.), Teacher thinking, beliefs and knowledge in higher education (pp. 210-239). Dordrecht: Kluwer Academic Publishers.

Korthagen, F. A. J. (2001). Waar doen we het voor? Op zoek naar de essentie van goed leraarschap. [What for? Searching for the essence of good teaching]. Inaugural address given at the acceptance of professorship in Didactics for teacher education at the IVLOS of the Utrecht University. Utrecht: WCC.

Lowyck, J. (1994). Teaching effectiveness: An overview of studies. Tijdschrift voor Onderwijsresearch, 19(1), 17-25.

Martin, E., Prosser, M., Trigwell, K., Ramsden, P., \& Benjamin, J. (2000). What university teachers teach and how they teach it. Instructional Science, 28, 387-412.

Moltmaker, T., \& Meulenkamp, H. (2000). Bekwaam beoordeeld. [Capably assessed]. VELON Tijdschrift voor lerarenopleiders, 21(3), 30-35.

Murry, J. W. J., \& Hammons, J. O. (1995). Delphi: a versatile methodology for conducting qualitative research. The Review of Higher Education, 18 (4), 423-436.

Prosser, M., \& Trigwell, K. (1999). Understanding learning and teaching: the experience in higher education. Buckingham: Open University Press. 
Putnam, R. T., \& Borko, H. (1997). Teacher learning: Implications of new views on cognition. In B. J. Biddle \& T. L. Good \& I. F. Goodson (Eds.), International handbook of teachers and teaching (pp. 1223-1296). Boston: kluwer.

Ramsden, P. (1992). Learning to teach in higher education. New York: Routledge.

Samualowicz, K., \& Bain, J. B. (1992). Conceptions of teaching held by academic teachers. Higher Education, 24, 93-111.

Samualowicz, K., \& Bain, J. D. (2001). Revisiting academics' beliefs about teaching and learning. Higher Education, 41, 299-325.

Saris, W., \& Stronkhorst, H. (1984). Causal modelling in nonexperimental research. Amsterdam, The Netherlands: Sociometric research Foundation.

Smith, K. S., \& Simpson, R. D. (1995). Validating teaching competencies for faculty members in higher education: a national study using the Delphi method. Innovative Higher Education, 19(3), 223-234.

Smith, R. G., \& Coldron, J. H. (1996). Mere competence or Personal Achievement? Is the specification of competences incompatible with a view of teaching as inescapably personal? Paper presented at the European Conference on Educational Research, Seville, Spain.

Stoof, A., Martens, R., van Merriënboer, J., \& Bastiaens, T. (2002). The boundary approach of competence: a constructivist aid for understanding and using the concept of competence. Human Resource Development Review, 1, 345-365.

Trigwell, K. (2001). Judging university teaching. The International Journal for Academic Development, $6(1), 65-73$.

Trigwell, K., \& Prosser, M. (1996). Congruence between intention and strategy in university science teachers' approaches to teaching. Higher Education, 32, 77-87.

Trigwell, K., Prosser, M., \& Waterhouse, F. (1999). Relations between teachers approaches to teaching and students' approaches to learning. Higher Education, 37, 57-70.

Twisk, T. F., Daniels, J. J. M. C., \& Bolweg, J. F. (1999). Competenties van leraren. [Teacher competencies]. Utrecht: Berenschot.

Uhlenbeck, A. M., Verloop, N., \& Beijaard, D. (2002). Requirements for an Assessment Procedure for Beginning Teachers: Implications from recent theories on teaching and assessment. Teachers College Record, 104(2), 242-272.

VELON (The Association for Teacher Educators in the Netherlands). (1999). Eerste versie Beroepstandaard lerarenopleiders. [First draft Professional standard teacher educators]. Diemen: VELON.

VSNU (The Association of Universities in the Netherlands). (1996). Raamplan voor de universitaire lerarenopleiding. [Framework for University teacher education]. Utrecht: VSNU.

Williams, P. L., \& Webb, C. (1994). The Delphi technique: a methodological discussion. Journal of Advanced Nursing, 19, 180-186. 


\section{3}

\section{Using a conceptual framework and the opinions of portfolio experts to develop a teaching portfolio prototype ${ }^{2}$}

Abstract. This paper reports the design of a prototype for a teaching portfolio for development and assessment purposes. A portfolio prototype was developed according to theoretical choices based on portfolio literature and Zeichner and Wray's (2001) conceptual framework. We conducted an interview study in which portfolio experts were asked to judge to what extent our theoretical choices were reflected in the prototype developed and which modifications were needed. In general, the experts agreed that our choices were reflected in the prototype developed. However, there were some controversial topics, which are discussed, as well as key issues for further research.

Keywords: Teaching portfolios, Teacher evaluation, Higher education

${ }^{2}$ This chapter has been published as: Tigelaar, E.H., Dolmans, D.H.J.M., Wolfhagen, H.A.P., \& Van der Vleuten, C.P.M. (2004). Using a conceptual framework and the opinions of portfolio experts to develop a teaching portfolio prototype. Studies in Educational Evaluation, 30 (3), 305-321. 


\section{Introduction}

In recent years, there has been a transition from testing to assessment, which has been characterized by the integration of assessment and learning (Gipps, 1994). Today, assessment is being viewed as a tool to enhance learning (Dochy \& McDowell, 1997). This means that assessment should be meaningful, authentic and challenging to candidates (Dochy, Segers, \& Sluijsmans, 1999). Moreover, both the learning process and the outcomes of this process must be assessed in a relevant context (Dierick \& Dochy, 2001). Feedback is a crucial factor in this process. An important notion in this respect is constructive alignment, i.e. optimal integration of assessment and learning process (Biggs, 1996, 1999). The effect of assessment on learning is referred to as consequential validity (Baud, 1995). Consequential validity is high when there is a constructive effect of assessment on performance, which is called a positive backwash effect. Assessments can also have adverse effects on performance (Burroughs, 2001). In such cases, the backwash effect does not encourage desired performance and may even have a negative impact, resulting in low consequential validity.

Insights on assessment have also changed in the field of teacher evaluation. It is acknowledged that assessment should be a positive learning experience, which means that assessments should be authentic, realistic and meaningful to the teachers who are being assessed (Uhlenbeck, Verloop, \& Beijaard, 2002). In addition, it is recognized that teaching should be assessed in the context (Darling-Hammond \& Snyder, 2000). Furthermore, multiple methods are needed and that information should be gathered over a period of time to obtain a comprehensive picture of teachers' knowledge and performance. Examples of such assessments are procedures that involve methods like simulations, peer assessment, co-assessment, self-assessment, and portfolios.

A teaching portfolio contains samples of a teacher's work collected over time across various contexts and accompanied by reflections (Wolf \& Dietz, 1998). Currently, teaching portfolios are increasingly being used in teacher education (Bird, 1990; Zeichner \& Wray, 2001). Since their introduction in the 1980s, portfolios have been expected to contribute to the development and improvement of both individual teachers and the teaching profession as a whole. Teaching portfolios are assumed to make teachers think more thoroughly about their teaching and subject matter content (Anderson \& DeMeulle, 1998; Bartell, Kaye \& Morin, 1998; Darling-Hammond \& Snyder, 2000). They are also intended to help teachers become more self-confident about their teaching practice and they are supposed to influence teachers' classroom practices in various ways. According to the recent literature on teachers and teacher learning, teachers are self-directed, meaningful learners who should show continuous professional development (Feiman-Nemser \& Remillard, 1996; Putnam \& Borko, 1997). In line with this view on teachers and teacher 
learning, the primary purpose of portfolio assessment should be to stimulate teachers to obtain more insight into their learning processes and help them revisit their own knowledge and express it in personally meaningful ways (Freidus, 1998). However, portfolios are also increasingly being used for certification and promotion decisions (Snyder, Lippincott, \& Bower, 1998). This suggests that portfolios are suitable tools for both development and assessment purposes.

Although portfolios are very popular in teacher education, they have been conceptualized and implemented in a variety of ways. In many cases, the construction of portfolios is not grounded in findings from the literature. Furthermore, portfolios are often intended as either a development or an assessment tool. It is a controversial issue whether these two functions can be combined in one procedure and how this should be done to achieve a constructive alignment of learning and assessment.

In this study we describe how we developed and tested a prototype of a teaching portfolio for development and assessment purposes. The prototype was designed for the purpose of providing teachers with more insight into their learning processes and supplying evidence for promotion decisions. We defined the theoretical positions that underpin the design of the prototype and developed a teaching portfolio in line with these theoretical positions. The portfolio was submitted to the judgments of educationalists with ample experience with portfolio assessment. The research question was: To what extent are our theoretical choices reflected in the prototype and which modifications are needed?

This paper is divided into five sections. Following the introduction, we describe a conceptual framework for portfolios proposed by Zeichner and Wray (2001) on the basis of the literature on portfolio assessment. In the subsequent section, we present the portfolio prototype that we developed on the basis of the definitions arrived at in the second section and the fourth section describes a study in which we asked portfolio experts to judge how well the portfolio prototype reflects the underlying theoretical concepts. In the final section we discuss the modifications of the prototype that we made in response to the experts' opinions.

\section{Defining the extremes of the dimensions in portfolio use}

Zeichner and Wray (2001) developed a conceptual framework for identifying different types of portfolio on the basis of portfolio practice and findings from the literature. Because of the considerable diversity in the implementation of teaching portfolios, they examined "the use of the teaching portfolio as an assessment and development tool in preservice teacher education programs in the US". The framework they developed was intended to help researchers to 
describe the approaches to teaching portfolios used in various settings. The framework consisted of the following dimensions: 1) the purposes of the portfolio, 2) who determines what goes into the portfolio and to what extent this is specified beforehand or left to the compiler of the portfolio, 3) the social interaction in the process of portfolio construction, and 4) what happens with portfolios once they have been completed. In order to make theoretical choices for the development of a portfolio prototype, we searched for the dimension extremes in Zeichner and Wray's conceptual framework, using additional portfolio literature. Furthermore, we adjusted the dimensions in the framework to our situation. In this section, the dimensions and their extremes are clarified. Finally, some controversial topics concerning the use of portfolios are highlighted.

\section{Portfolio purpose}

The first dimension in Zeichner and Wray's conceptual framework is portfolio purpose. Several portfolio purposes can be distinguished (Bird, 1990; Wolf \& Dietz, 1998; Zeichner \& Wray, 2001; Van Tartwijk, Driessen \& Rubens, 2004). The purpose of a "learning portfolio" is to engage teachers in inquiry about their teaching and to document growth in teaching performance and teacher knowledge over time. A learning portfolio provides structure for the teachers' self-reflection as to which areas of their teaching performance are in need of improvement. This kind of portfolio is also called a "professional growth portfolio". The "credential portfolio" is used to assess a prospective teacher's readiness to be given an initial teaching license and a "showcase portfolio" presents the best work of a teacher. Credential and showcase portfolios are used to take decisions, for example about certification or promotion. In summary, two main portfolio purposes can be distinguished: a formative purpose, i.e. to stimulate learning and professional development and a summative purpose, i.e. to take promotion decisions (Edgerton, Hutchings, \& Quinlan, 1991; Seldin, 1991). These two purposes can be seen as the extremes of the 'portfolio purpose dimension'.

\section{Portfolio organization and evidence}

The second dimension concerns 'who determines what goes into the portfolio and to what degree this is specified beforehand or left to the portfolio compiler to determine'. We have adapted this dimension to focus on the organization of the portfolio process and the type of evidence to be included in the portfolio and therefore, we call this dimension 'portfolio organization and evidence'. The extremes of this dimension are: open-ended and tightly organized for organization and non-standardized versus standardized for evidence. If portfolios are open-ended, this means that there are no specific requirements for portfolio organization; it is all left open-ended to the portfolio compiler's 
choice. Not only portfolio organization, but also the type of evidence included in the portfolio can range from highly varied sources of evidence to a clearly specified set of teacher work (Wolf \& Dietz, 1998). A well-known categorization divides portfolio content into (1) material from oneself, for instance a statement of teaching responsibilities, course syllabi and self-evaluations; (2) material from others, such as feedback from peers or students; and (3) products of good teaching, such as evaluations by students and information about the effects of courses on student career choices (Seldin, 1991). Most portfolio programs are likely to include a combination of prescribed and self-selected evidence (Barton \& Collins, 1993). However, it is not only the degree of specification that is important, the key distinction is the one between materials that provide nonstandardized versus standardized information (Peterson, 1995; 2001). The content of most portfolios consists of work samples, lesson plans and feedback from students and colleagues and these materials are often qualitative and nonstandardized. The interpretation of this type of evidence requires a great deal of effort (Delandshere \& Petrosky, 1998), whereas standardized content, such as uniform rating scales for peer-, student-, or self-evaluations, can be interpreted at a single glance.

\section{Social interactions in the process of portfolio construction}

The third dimension is that of 'the nature and quality of social interactions in the process of portfolio construction'. As Edgerton et al. (1991) put it, portfolios can foster a culture of teaching and a new discourse about it. The extreme positions on this dimension are orientation on the process of creating a portfolio or orientation on the ensuing product (Darling, 2001; Loughran \& Corrigan, 1995; Meyer \& Tusin, 1999). Because learning is a social process, portfolio construction should be so too. In the process of constructing a portfolio, teachers gain insight into their learning processes and learn about their professional development. Reflection and feedback are crucial in this process (Tillema \& Smith, 2000). It has been argued that the value of teaching portfolios can be greatly enhanced by enabling teachers to interact with others on a regular basis when they are constructing their portfolios (Seldin, 1991; Wolf \& Dietz, 1998). Examples of social interaction are meetings with peers or supervisors (Freidus, 1998). By helping portfolio composers to select materials and reflect on them, coaches and supervisors can provide important support for the cognitive and emotional components that play a role in portfolio construction. Peer coaching can be a very useful way of obtaining feedback and advice from colleagues. In interactions in relation to the portfolio construction process it is often the teachers' learning goals that are the focal point. By contrast, social interactions concerning the portfolio as a product focus on the selection of portfolio items for use in promotion decisions. In this case, portfolio composers discuss what constitutes good teaching and which items best represent their performance. 


\section{Portfolio assessment}

The fourth dimension is related to 'What happens with the portfolio once it is completed'. We modified this dimension to focus on assessment, and therefore, we will refer to it as such. The extreme positions on this dimension are holistic and analytic assessment. With holistic assessment, assessors seek to understand the whole of the portfolio in the light of its constituents by continually testing, challenging and revising their interpretations until all the available evidence has been accounted for (Moss, Schutz \& Collins, 1998). In this process the teacher's learning goals are often used as the point of departure (Wolf \& Dietz, 1998). Holistic assessment is often combined with a learning dialogue, in which assessors give teachers feedback about areas that need improvement and involve them in a debate about what constitutes good teaching (Moss, Schutz, \& Collins, 1998). Analytical portfolio assessment, on the other hand, uses more precise, uniform standards and standardized rating procedures.

These four dimensions of portfolio use and their extremes are presented in Table 3.1. It is evident from the table that in many cases the purpose of the portfolio determines the position on the other dimensions. Portfolios for formative evaluation are often open-ended or loosely organized and contain mostly non-standardized materials. For formative purposes, social interaction around portfolio construction is focused on the process of portfolio construction and assessment is usually holistic. Portfolios for summative purposes, on the other hand, are often highly structured and contain evidence in the form of prescribed and standardized materials. Social interaction focuses on the portfolio as a product and assessment is analytic and according to well-defined criteria. This means that the intended purposes of the portfolio influence how the portfolio process and content are organised, used and assessed. It should be noted, however, that Table 3.1 only presents the most extreme theoretical positions.

\section{Controversy concerning the different uses of portfolios}

There is some controversy concerning the different uses of portfolio. First, it is often argued that the formative and summative functions of portfolio cannot be combined (Edgerton et al., 1991; Seldin, 1991; Wolf \& Dietz, 1998). However, Snyder et al. (1998) contend that it might be preferable not to separate these two functions, because high stakes decisions, such as certification or promotion decisions, are best made on the basis of information that is gained through context-specific relationships and conversations inherent in an over-time support role. This means that information that is collected during the formative phase may be highly relevant for summative decisions. 
Table 3.1. The dimension extremes of Zeichner and Wray's (2001) conceptual framework of portfolio use

\begin{tabular}{|c|c|c|}
\hline \multirow{2}{*}{$\begin{array}{l}\text { Dimensions } \\
\text { Portfolio purpose }\end{array}$} & \multicolumn{2}{|c|}{ Extremes } \\
\hline & Formative evaluation & Sumnative evaluation \\
\hline & $\begin{array}{l}\text { Stimulate teacher development } \\
\text { and professional development }\end{array}$ & $\begin{array}{l}\text { Take decisions about promotion } \\
\text { \& licence }\end{array}$ \\
\hline \multirow{5}{*}{$\begin{array}{l}\text { Portfolio organization and } \\
\text { evidences }\end{array}$} & Open-ended & Tightly Organized \\
\hline & No structure is provided & $\begin{array}{l}\text { A clear prescribed structure is } \\
\text { given }\end{array}$ \\
\hline & Highly varied & Prescribed \\
\hline & Non-standardized & Standardized \\
\hline & $\begin{array}{l}\text { Composers are free to chose } \\
\text { materials that need } \\
\text { interpretation }\end{array}$ & $\begin{array}{l}\text { Composers should add } \\
\text { prescribed materials that need } \\
\text { no interpretation }\end{array}$ \\
\hline Social interaction in the process & Process & Product \\
\hline of constructing the portfolio & $\begin{array}{l}\text { Focus is on the process of } \\
\text { constructing a portfolio and on } \\
\text { teacher development }\end{array}$ & $\begin{array}{l}\text { Focus is on the final product of } \\
\text { the portfolio and on best } \\
\text { performance }\end{array}$ \\
\hline \multirow[t]{2}{*}{ Portfolio assessment } & Holistic & Analytical \\
\hline & $\begin{array}{l}\text { The portfolio is assessed in a } \\
\text { holistic way, according to } \\
\text { teachers' learning goals }\end{array}$ & $\begin{array}{l}\text { The portfolio is assessed in an } \\
\text { analytical way, according to } \\
\text { precise criteria }\end{array}$ \\
\hline
\end{tabular}

The second controversy concerns portfolio organization and evidence. Edgerton et al. (1991) and Seldin (1991) maintain that portfolios that are used for promotion decisions should be tightly structured and consist predominantly of prescribed, standardized evidence in order to ensure comparability of candidates and reliable rating. Moss (1994), on the other hand, argues that standardization of portfolio organization and entries would jeopardize validity, because it would lead to a less rich picture of the teacher in various contexts. The third issue is the role of the support provider, i.e. the coach, in summative assessment. Although it is a common view that the role of support provider should be strictly separated from the assessor role, Driessen, Van Tartwijk, Vermunt, \& Van der Vleuten (2003) argue in favor of a portfolio assessment committee that is composed of coaches on the grounds that it is the coaches who are most familiar with the candidates' work. They have applied this principle in a portfolio assessment procedure for university students (Driessen, Van der Vleuten, Schuwirth, Van Tartwijk, \& Vermunt, 2005). However, coaches do not assess their own students' portfolios. They only make the initial recommendations for the assessment of the portfolios. Snyder et al. (1998) also state that evaluators may have to be support providers. The assessment method of portfolios also provides topics for debate. It is said of analytic, uniform assessment criteria that they would enable reliable and consistent rating, but that on the other hand they might reduce consequential validity and provoke negative backwash effects, forcing teachers to focus exclusively on those elements of teaching that they know will be assessed (Burroughs, 2001). 
Furthermore, it is argued that evaluators should also provide support in the form of feedback during the process of constructing a portfolio (Snyder et al., 1998). This need for a learning dialogue, in which feedback is provided throughout the portfolio procedure, in both the formative and summative phases, has also been stressed by others (Delandshere \& Arens, 2003; Moss et al., 1998).

\section{Developing a portfolio prototype}

We used the described framework to develop a prototype for a teaching portfolio that is intended to give teachers more insight into their learning processes and for use in making promotion decisions. The prototype is thus designed to serve the dual purpose of teacher development and teacher assessment. This requires a careful balance between the extreme positions on the dimensions of the described framework.

The portfolio prototype was specifically developed for providing experienced university teachers with more insight into their learning processes in teaching and for making promotion decisions, i.e. decisions regarding the feasibility of a teaching career on the basis of teaching performance.

Portfolio assessment should be based on a framework that provides guidelines about what is expected of teachers. Several frameworks for teacher evaluation have been developed, like those of the Scottish Executive (2002) and the National Board for Professional Teaching Standards (1999). These frameworks cover important aspects of teaching, such as: professional knowledge and understanding of pedagogy, guidance and advising, designing curriculum and course materials, appropriate assessment and feedback; professional and personal attributes, such as interest and explanation, concern and respect for students and student learning, clear goals and intellectual challenge; content knowledge of - the subjects that are to be taught; organizational competencies and collaboration with colleagues in the learning community; and personal commitments to lifelong learning and critical reflection. As a guideline for structuring portfolios, our prototype involves asking the teachers to reflect on different teaching domains: the person as teacher, the teacher as content knowledge expert, the teacher as facilitator of learning processes, the teacher as organiser and the teacher as a scholar/lifelong learner (Tigelaar, Dolmans, Wolfhagen \& Vander Vleuten, 2004). These teaching roles were derived from the above-mentioned aspects of teaching, but the role of the person as teacher was added as a new role that focuses on less common aspects, which were recently introduced as important for teacher functioning, such as the teacher's professional identity (how the teacher views him/herself as a teacher), the teacher's beliefs about students and teaching and the teacher's mission or commitment to teaching (Korthagen, 2004). The domains are not 
prescriptive, but serve as starting points for structuring the portfolio. Guiding questions were formulated for each domain to stimulate teachers to think about their teaching. Teachers have to describe their activities in these domains, reflect on them, and set learning goals. In the reflection, teachers should ask themselves the following questions: 'What did I learn?', 'Which points need improvement?', and 'What steps will I take to work on my learning goals?'. In addition to the guiding questions, teachers are given some suggestions for evidence to be included in the portfolio, but teachers are generally stimulated to be creative in adding evidence, such as materials they have produced themselves, contributions from peers and students, and products of good teaching. The teachers are instructed to include both standardized and nonstandardized materials. The domains of teaching and the guiding questions are intended as starting points for the teachers which they can use in setting their learning goals and selecting evidence. We did not want the domains and guiding questions to hamper teachers' creativity in compiling their portfolios.

The combined development and assessment purposes of the portfolio imply that the portfolio should be neither too highly organized nor completely openended. In addition, some suggestions for evidence, both standardized and nonstandardized, are provided, but the candidates are also encouraged to include some self-selected materials in their portfolio. Thus the portfolio prototype is partly open-ended and partly prescribed. The social interaction around portfolio construction focuses on the portfolio both as process and as product. A coach, i.e. an experienced teacher who is able to provide support on teaching performance and stimulate reflection, will explain the procedure and provide teachers with feedback. In the initial stages, these coaches are expected to focus on the process of constructing the portfolio and use the teacher's learning goals and the guiding questions as starting points in providing feedback. At a later stage of the portfolio process, the emphasis in the coaches' role shifts to helping teachers select what to include in the portfolio as a product to be submitted to the assessment committee. In this way the coaches are able to provide support in both purposes of the portfolio, i.e. they stimulate teachers' learning processes when constructing their portfolio and subsequently they assist in compiling the finished product that can be assessed.

Finally, the prototype portfolio has been designed for assessment by an assessment committee that gives a global judgment, using the guiding questions and the candidates' learning goals as points of departure. We wanted to strike an appropriate balance between holistic and analytic assessment. We also wanted the assessment committee to discuss their decisions with the candidates and give them feedback. The coaches were to act as advisers to the assessment committee about the candidates they coached, because they know these candidates best. The teachers had the option of adding a variety of evidence to their portfolio as examples of best performance before submitting 
the portfolio to the assessment committee. The described process shows that the prototype portfolio combines development and assessment purposes in the same structure, with candidates working with the same coach towards the decision about promotion and assessment by a committee, which engages in dialogue with the candidates about their decision and provides feedback. In this way, the summative decision about teachers' promotion is a continuation of the formative process (Delandshere \& Arens, 2003; Moss et al., 1998). Table 3.2 specifies the choices with respect to the dimensions of Zeichner and Wray's (2001) conceptual framework which we made in designing the portfolio prototype.

Table 3.2. Summary of theoretical choices with respect to the elements in Zeichner and Wray's (2001) conceptual framework

\begin{tabular}{ll}
\hline Dimensions & Choices based on conceptual framework \\
\hline Portfolio purpose & $\begin{array}{l}\text { Portfolio should be useful for formative and summative } \\
\text { evaluation }\end{array}$ \\
$\begin{array}{l}\text { Portfolio organization and evidential } \\
\text { materials }\end{array}$ & $\begin{array}{l}\text { The portfolio will not be totally open-ended } \\
\text { Some freedom to add materials that include both non- } \\
\text { standardized and standardized materials }\end{array}$ \\
$\begin{array}{l}\text { Social interaction in the process of } \\
\text { constructing the portfolio }\end{array}$ & $\begin{array}{l}\text { Focus will first be on the process of making a portfolio and } \\
\text { later on product and best performance } \\
\text { Portfolio assessment }\end{array}$ \\
\hline
\end{tabular}

\section{Evaluation of the prototype by experts}

\section{Participants}

Nine portfolio experts were invited to participate in individual interviews to assess whether the prototype portfolio reflected its theoretical underpinnings. These experts were educationalists with teaching experience in higher education and particular expertise in the domain of assessment. They all had had practical experience with portfolios in higher education and five of them had been involved in research into portfolio assessment. Five of them were female and four were male. 


\section{The interview protocol}

The semi-structured interviews were conducted by one of the authors (DT) and lasted approximately 90 minutes. We used the general interview guide approach (Patton, 1990) to develop an open-ended interview protocol that was based on the dimensions of the protocol framework, i.e. purpose, organization and evidence, social interaction and assessment. These themes were not discussed in any fixed order, since they are closely interrelated. The central question for each theme was: to what extent does the prototype portfolio reflect the theoretical choices made by the designers and what modifications would you recommend? The interview guide contained specific questions about: (1) the extent to which the prototype was suitable for both formative and summative purposes; (2) whether the organization of and the evidence included in the prototype were neither too tightly structured nor completely open ended; (3) the extent to which the social interaction around portfolio construction in the prototype was initially focused on the portfolio as a process and at a later stage on the portfolio as a product; and finally, (4) whether the prototype provided assessment committees with sufficient clues for making a global judgment of the portfolio and provide candidates with feedback.

\section{Analysis}

The interviews were audio taped and an overview of the responses of each interviewee was made. We analyzed the content of the interviews using a topdown strategy (Miles \& Huberman, 1994a, 1994b). The categories used in the analysis were: portfolio purpose, portfolio organization and evidence, social interaction in portfolio construction and portfolio assessment. The analysis was performed in two phases. First, we compared the answers of each interviewee with our position concerning the dimensions of portfolio use in a case analysis (Patton, 1990). Next, we examined agreement and disagreement among the interviewees concerning the underpinnings of the portfolio prototype. In the second phase, we performed a cross-case analysis comparing individual answers and grouping them by category and trying to find a pattern. To ensure that the analysis was of adequate quality, the first and second author performed the two phases of the analysis independently of each other, listing the main points made by each interviewee and searching for reasons given by the experts to support their opinions. In a consensus procedure, the first, second and third author selected the most illustrative quotes for the main reasons given by the experts to support their opinions. 


\title{
Results of the interviews
}

\section{Portfolio purpose}

The interviewees generally agreed that the prototype was appropriate for both formative and summative purposes. However, some interviewees argued that the formative and summative purposes are incompatible, because they involve different portfolio organization and requirements for evidence. On the other hand, others said that the two purposes are not mutually exclusive and that teachers who work on a portfolio for a formative goal are often more motivated to work seriously on their portfolio when they can also work toward a formal, summative goal like a promotion decision.

\begin{abstract}
"Summative assessment is a continuation of formative assessment. These two purposes should not be viewed as separate. Moreover, for formative assessment, it is useful to have some sort of reward, such as a promotion decision, so that portfolio composers have a goal towards which they can work. If portfolio construction is kept too informal, composers tend to do their job very poorly. (I.2)"
\end{abstract}

\section{Portfolio organization and evidence}

The interviewees stated that portfolio organization and evidence were not too strictly prescribed nor too open-ended. The experts were generally agreed that the teaching domains provided appropriate starting points for structuring a teaching portfolio. However, the participants varied in their opinions about the guiding questions. The argument was raised that guiding questions might prevent portfolio composers from formulating their own learning goals. In this sense, the guiding questions were viewed as too prescriptive and more appropriate for summative evaluation. Conversely, it was said that guiding questions might be useful to illustrate the domains as long as they were explicitly introduced as guidelines and not as checklists. It was also said that, although suggestions as to the inclusion of evidence in the portfolio may be helpful, it is also important that portfolio composers are stimulated to include materials of their own choice. Similar comments were made about the guiding questions, which the interviewees thought should be seen as illustrative examples of the main categories. The teachers should be free to decide whether to answer these questions or not.

"The domains are appropriate as long as the guiding questions are presented and applied as examples that make it clear what is meant by the main categories and not as requiring a response (I.6)".

Social interactions in the process of portfolio construction

The interviewees generally agreed that the prototype's plans for social interaction around portfolio construction were initially focused on the portfolio 
as a process and at a later stage on the portfolio as a product. The interviewees supported our view that it is important that the focus should initially be on the construction process to stimulate teachers' learning and development. It was stressed that portfolio composers should have many opportunities for discussing their learning goals and learning processes and for receiving feedback. There was agreement that having a coach is a good thing, but the suggestion was also made to organize meetings for peers. Another comment regarding the coaches was that they should be experienced in teacher roles and be familiar with the subject taught by a candidate. Furthermore, it was considered desirable that the coaches should be competent in asking questions that stimulate reflection on teachers' cognitions and beliefs.

"Professional development involves more than performance improvement. Beliefs about teaching and learning, which often remain implicit, are very influential for teacher behavior. Therefore, in the process of constructing portfolios, coaches should not only ask 'what' and 'how' questions, but also 'why' questions (I.5)."

\section{Portfolio assessment}

The issue of portfolio assessment became salient in the interviews. Comments concerned the role of the coach in assessing a candidate. In the prototype it was proposed that each portfolio composer had a coach who explained the procedure, helped in selecting materials and in writing reflections and who gave advice about a candidate to the assessment committee. The experts had different opinions about the position of the coach in the summative assessment. On the one hand, there was agreement with our view that the coach is the most appropriate person to advise the assessment committee about a candidate. On the other hand, there were those who argued that it is unethical for the coach to take on an assessor role. Portfolio composers must feel free to reflect on their professional development together with their coach, knowing that $\mathrm{s} / \mathrm{he}$ will not pass any information on to others. The majority of the experts was of the opinion that the coach should not be involved in summative assessment nor make recommendations to the assessment committee.

There was also discussion about the use of assessment criteria. In general, the interviewees said that for assessment purposes, criteria are prerequisite and that guiding questions might be appropriate for this purpose. On the other hand, however, it was argued that no assessment criteria should be set beforehand, because they would draw teachers' attention towards what was expected of them by the assessment committee. This might encourage teachers to be very selective in adding items to their portfolios, which would not benefit the validity of the assessment and result in a less rich picture of teachers' performance and learning process. As an alternative to setting assessment criteria in advance, it was proposed that assessors with different perspectives on teaching should be selected and that they should be allowed to explain their 
own criteria. In general, there was agreement that feedback from assessors to candidates is crucial to make summative portfolio assessment a worthwhile learning experience for candidates.

"Coaches should be independent and candidates must feel free to talk to their coaches about their teaching concerns. This implies that the formative and summative function should not be united within one person. Candidates do not need an advocate. They should defend themselves (I.8)."

\section{Discussion and modification of the portfolio prototype}

The purpose of this study was to develop a prototype of a teaching portfolio for development and assessment purposes. The portfolio was intended for use by experienced university teachers to give them more insight into their learning processes and also to be used as a basis for promotion decisions. The design of the prototype was based on the portfolio literature and on a framework developed by Zeichner and Wray (2001) in particular. We asked portfolio experts whether the theoretical underpinnings of the choices made in designing the prototype were reflected in the prototype and what modifications, if any, they considered necessary. There was general consensus among the experts that the prototype actually reflected our theoretical choices. However, some points of discussion were raised. We will discuss the controversial issues for each of the dimensions of the portfolio prototype and explain how we have modified the original prototype in accordance with the experts' recommendations.

An important issue with respect to portfolio purpose was the relationship between formative and summative assessment. There was disagreement as to whether these two purposes could be combined in one portfolio. Some interviewees agreed with Edgerton et al. (1991) and Seldin (1991) that these purposes are incompatible, but other interviewees were of the opinion that the two purposes are not mutually exclusive and cannot be fully separated. The latter view is supported by Snyder et al. (1998), who concluded that the accountability function of portfolios may not be separable from the support function, seeing that information collected during the formative phase can be very useful for summative decisions and given the importance of feedback to candidates by evaluators. This implies that even when assessing teachers' performance for promotion purposes, learning and professional development should be the primary purposes. In this respect, it is crucial that the learning dialogue that is started in the formative phase of portfolio assessment should be ongoing and that assessors should engage in discussion with candidates about their performance, providing them with suggestions for improvement (Moss, et al., 1998). Finally, the interviewees set out another argument in favor of 
combining the formative and summative function: teachers' motivation for constructing a portfolio might be enhanced when the portfolio is also used for assessment purposes, including promotion decisions. On the basis of these results we conclude that portfolio construction should be focused on both development and assessment purposes. Initially, the selection of portfolio content and reflections included in the portfolio should be primarily focused on learning goals for development purposes, whereas at a later stage the emphasis should shift to evidence that is suitable for presentation to the assessment committee.

As regards the dimension of portfolio organization and evidence, interviewees' opinions differed about the use of guiding questions and recommendations for inclusion of specific evidence. It was argued that such prescriptive directions might hamper candidates' creativity and learning processes. This adverse effect is also mentioned as a negative backwash effect by Baud (1995 and Burroughs (2001). The interviewees suggested that it might be preferable to offer structure along the lines of different teaching domains rather than through guiding questions. When the portfolio prototype is piloted, the teachers will be asked to set their own learning goals for each teaching domain and we have decided to omit the guiding questions as being too prescriptive.

The dimension of social interaction in the process of portfolio construction met with unanimous approval of the proposed approach that the focus should first be on the portfolio construction process and later on the portfolio as product and evidence of best performance. There was general agreement that it is good for a teacher to have a coach in the portfolio process, provided the coach is familiar with teaching and with the subject that is taught by a candidate. It was also said that coaches should be competent in asking questions that stimulate reflection on teacher's cognitions and beliefs. For the practical implementation of the teaching portfolio this implies careful selection of coaches and possibly also training of coaches. Another important suggestion of the interviewees was that during the process of portfolio construction composers should be able to meet with colleagues. For this reason, the prototype will include sessions in which the portfolio composers can meet with peers.

The fourth dimension, i.e. portfolio assessment, gave rise to debate on two issues. First, although it seems that the interviewees supported our view that having a coach is a good thing generally, the coach's task and position proved controversial. The interviewees argued that, because the relationship with a coach should be a safe one, it was not advisable for the coach to make recommendations to the assessment committee, as is reported by Driessen et al. (2005). The interviewees objected to the formative and summative function being vested in one and the same person. This insight is in line with Freidus 
(1998), who stresses that portfolio composers take a huge risk when they share their personal and professional development with their coach. These arguments made us decide to abandon our initial plan of having the coach make recommendations to the assessment committee.

The interviewees also objected to assessment criteria that were set beforehand, because this would focus teachers' attention too much on what is expected of them by the assessment committee. It was said that this might encourage teachers to be very selective in including items in their portfolios, which would lessen the richness of the picture provided by the portfolio and thus mitigate the validity of the assessment. This undesirable consequence of the use of assessment criteria involves a potential negative backwash effect of assessment (Baud, 1995; Burroughs, 2001). A worthwhile suggestion that was made by the interviewees in this respect was to select assessors with different perspectives on teaching who would explain their own criteria instead of setting criteria beforehand. However, it was also said that criteria were necessary for assessment purposes and that guiding questions might be appropriate for this purpose. Despite general agreement that feedback is crucial in making summative portfolio assessment a worthwhile learning experience, portfolio assessment clearly raises some concerns that needs further attention. The assessment procedure requires further development and guidelines for portfolio assessment and feedback are needed for implementation of the portfolio in practice.

Finally, the limitations of this study are that none of the interviewed experts was primarily working as a teacher. The reason that we interviewed researchers instead of teachers was that the focus of the interview was on the theoretical underpinnings of the prototype. Second, this paper focuses on experts' opinions on a prototype and how it was developed on the basis of a conceptual framework. The prototype will first have to be piloted and tested before more recommendations for its practical application can be made. The prototype will be field-tested in an experiment involving experienced university teachers.

\section{References}

Anderson, R. \& DeMeulle, L. (1998). Porfolio use in twenty-four teacher education programs. Teacher Education Quarterly, 25(1), 23-32.

Bartell, C. Kaye, C. \& Morin J.A. (1998). Teaching portfolios in teacher education. Teacher Education Quarterly, 25(1), 5-8.

Barton, J., \& Collins, A. (1993). Portfolios in teacher education. Journal of Teacher education, 44, 200210.

Baud, D. (1995). Enhancing Learning through Self Assessment. London: Philadelphia: Kagan Page.

Biggs, J. (1996). Enhancing teaching through constructive alignment. Higher Education, 32, 347-364. 
Biggs, J. (1999). Teaching for quality learning at University. Buckingham: SRHE Open University Press. Bird, T. (1990). The schoolteacher's portfolio: an essay on possibilities. In J. Millman \& L. E. DarlingHammond (Eds.), The new handbook of teacher evaluation. Assessing elementary and secondary schoolteachers (pp. 241-256). Newbury Park: CA: Corwin Press Inc.

Burroughs, R. (2001). Composing standards and composing teachers. Journal of teacher education, $52(3), 223-232$.

Darling, F. L. (2001). Portfolio as practice: the narratives of emerging teachers. Teaching and Teacher Education, 17, 107-121.

Darling-Hammond, L., \& Snyder, J. (2000). Authentic assessment of teaching in context. Teaching and Teacher Education, 16, 523-545.

Delandshere, G., \& Arens, S. A. (2003). Examining the quality of the evidence in preservice teacher portfolios. Journal of Teacher Education, 54(1), 57-73.

Delandshere, G., \& Petrosky, A. R. (1998). Assessment of Complex Performances: Limitations of Key Measurement Assumptions. Educational Researcher, 27(2), 14-24.

Dierick, S., \& Dochy, F. (2001). New lines in edumetrics: new forms of assessment lead to new assessment criteria. Studies in Educational Evaluation, 27, 307-329.

Dochy, F., Segers, M., \& Sluijsmans, D. (1999). The use of Self-, Peer and Co-assessment in Higher Education: a review. Studies in Higher Education, 24(3), 331-350.

Dochy, F., \& McDowell, L. (1997). Assessment as a tool for learning. Studies in Educational Evaluation, 67(23), 279-298.

Driessen, E. W., Van der Vleuten, C. P. M., Schuwirth, L. W. T., Van Tartwijk, J., \& Vermunt, J. (2005). The use of Qualitative research criteria for portfolio assessment as an alternative to reliability evaluation: a case study. Medical Education, 39(2), 214-220.

Driessen, E. W., Van Tartwijk, J., Vermunt, J., \& Van der Vleuten, C. P. M. (2003). Use of portfolios in early undergraduate medical training. Medical teacher, 25(1), 18-23.

Edgerton, R., Hutchings, P., \& Quinlan, K. (1991). The teaching portfolio: capturing the scholarship in teaching. Washington D.C.: AAHE.

Feiman-Nemser, S., \& Remillard, J. (1996). Perspectives on learning to teach. In F. B. Murray (Ed.), The teacher educator's handbook: Building a knowledge base for the preparation of teachers (pp. 6391). San Fransisco: Jossey Bass.

Freidus, H. (1998). Mentoring portfolio development. In N. Lyons (Ed.), With portfolio in hand: Validating the new teacher professionalism (pp. 51-68). New York, London: Teachers College Press.

Gipps, C. V. (1994). Beyond testing: Towards a theory of educational assessment. London, Washington D.C.: Falmer Press.

Korthagen, F. A. J. (2004). In search of the essence of a good teacher: towards a more holistic approach in teacher education. Teaching and Teacher Education, 20, 77-97.

Loughran, J., \& Corrigan, D. (1995). Teaching portfolios: a strategy for developing learning and teaching in preservice education. Teaching and Teacher Education, 11(6), 565-577.

Meyer, D. K., \& Tusin, L. F. (1999). Preservice teachers' Perceptions of Portfolios: Process versus Product. Journal of Teacher Education, 50, 131-139.

Miles, M. B., \& Huberman, A. M. (1994a). Matrix Displays: Some rules of Thumb. In M. B. Miles \& A. M. Huberman (Eds.), Qualitative Data Analysis. Thousand Oaks: Sage publications. 
Miles, M. B., \& Huberman, A. M. (1994b). Within-case Displays: Exploring and Describing. In M. B. Miles \& A. M. Huberman (Eds.), Qualitative Data Analysis. Thousand Oaks: Sage Publications.

Moss, P. M. (1994). Can there be validity without reliability? Educational Research, 23(2), 5-12.

Moss, P. M., Schutz, A. M., \& Collins, K. M. (1998). An integrative approach to portfolio evaluation for teacher licensure. Journal of Personnel evaluation in education, 12(2), 139-161.

National Board for Professional Teaching Standards. (1999). What teachers should know and be able to do. Washington, DC: NBPTS.

Patton, M. Q. (1990). Qualitative Evaluation and Research Methods. Newbury Park, California: SAGE Publications Inc.

Putnam, R. T., \& Borko, H. (1997). Teacher learning: Implications of new views on cognition. In B. J. Biddle, T. L. Good \& I. F. Goodson (Eds.), International handbook of teachers and teaching (pp. 1223-1296). Boston: kluwer.

Scottish Executive. (2002). Standard for the Chartered Teacher. GTC Scotland, EIS, COSLA, Scottish Executive.

Seldin, P. (1991). The teaching portfolio: a practical guide to improved performance and promotion/tenure decisions. Bolton: MA: Anker.

Snyder, J., Lippincott, A., \& Bower, D. (1998). The inherent tensions in the multiple use of portfolios in teacher education. Teacher Education Quarterly, 25(1), 45-60.

Tigelaar, E. H., Dolmans, D. H. J. M., Wolfhagen, H. A. P., \& Van der Vleuten, C. P. M. (2004). The development and validation of a framework for teaching competencies in higher education. Higher Education, 48, 253-268.

Tillema, H. H., \& Smith, K. S. (2000). Learning from portfolios: differential use of feedback in portfolio construction. Studies in Educational Evaluation, 26, 193-210.

Uhlenbeck, A. M., Verloop, N., \& Beijaard, D. (2002). Requirements for an Assessment Procedure for Beginning Teachers: Implications form recent theories on teaching and assessment. Teachers College Record, 104(2), 242-272.

Van Tartwijk, J., Driessen, E. W., \& Rubens, W. (2004). Functions of Electronic Portfolios in Higher Education. In P. Boezerooy \& P. Gorissen (Eds.), Dutch E-Learning in Europe (pp. 8-10). Utrecht: SURF.

Wolf, K., \& Dietz, M. (1998). Teaching portfolios; Purposes and Possibilities. Teacher Education Quarterly, 25(1), 9-22.

Zeichner, K., \& Wray, S. (2001). The teaching portfolio in US teacher education programs: what we know and what we need to know. Teaching and Teacher Education, 17, 613-621. 


\section{4 \\ Portfolio as a tool to stimulate teachers' reflections ${ }^{3}$}

Abstract. Portfolios are increasingly being used to stimulate teachers' reflections. Frameworks for reflection on teaching often emphasise competencies and behaviours. However, other aspects of teacher functioning are also important, such as the teaching environment and individual teachers' beliefs, professional identity and mission. In a study among five medical school teachers, we explored how a portfolio stimulated reflections on the various aspects of teaching functioning.

Outcomes of written portfolio assignments were collected and analysed to identify examples of reflections on the various aspects of teacher functioning.

Examples of reflections on all aspects of teacher functioning were found, although examples of reflections on competencies were easier to find than those on beliefs, identity and mission.

This study might help teachers and their trainers and coaches to recognise different aspects of teacher functioning when discussing portfolios for professional development purposes. However, further development of assignments and other methods to stimulate reflections on beliefs, identity and mission are needed. Furthermore, apart from the content of teachers' reflections, teachers' reflection processes should be researched, as well as the effects of portfolio meetings with peers and coaches.

Keywords: Reflection, Portfolio, Teacher development.

${ }^{3}$ This chapter has been accepted for publication in Medical Teacher as: Tigelaar, E.H., Dolmans, D.H.J.M., De Grave, W.S., Wolfhagen, H.A.P., \& Van der Vleuten, C.P.M. Portfolio as a tool to stimulate teachers' reflections. 


\section{Introduction}

Portfolios were introduced mainly to assess performance in authentic contexts and stimulate users to reflect on their functioning (Snadden, 1999; Davis et al. 2001: Driessen et al. 2003). Since the first introduction of teaching portfolios in the eighties, several approaches to portfolio use have been proposed (Wolf \& Dietz et al., 1998; Zeichner \& Wray, 2001; Webb et al. 2002). Portfolios are increasingly being used as tools to contribute to the development and growth of individual teachers and to the improvement of the teaching profession as a whole (Zeichner \& Wray, 2001; Bird, 1990). Teaching portfolios are expected to foster teachers' awareness of their teaching and the subject matter they teach (Anderson \& DeMeulle, 1998; Bartell et al., 1998; Darling-Hammond\& Snyder, 2000). When constructing a portfolio, teachers are encouraged to examine their own learning processes and their professional development (Darling, 2001; Loughran \& Corrigan, 1995). Portfolios have been found to be a valuable tool in continuing professional development, because they support active and peersupported learning and stimulate self-confidence and professional growth (Mathers et al., 1999; Friedman et al., 2001; Gordon, 2003; Rees \& Sheard, 2004).

Although it is often emphasised how important reflection, i.e.: deeper thinking about teacher functioning, is for teachers, it is not always quite clear what teachers should reflect on within the context of their professional development (Korthagen, 2004). Frameworks for reflection on teaching frequently focus on teacher behaviours (what teachers are actually doing in the classroom, i.e. performance) and competencies (what teachers are potentially able to do). Although it is obviously important that teachers reflect on teaching behaviours and competencies as part of their striving for professional improvement, the recent literature on teaching also points to the relevance of other aspects of teacher functioning. One of these aspects is teachers' working environment, i.e. course design, institutional philosophy and student characteristics (Ramsden, 1992; Kember \& Kwan, 2002). Another aspect that is known to affect teaching are teachers' perceptions or beliefs about students, learning and knowledge (Kember, 1997; Martin et al., 2000; Hativa \& Goodyear, 2002). An important contribution is also made by teachers' approaches to teaching, their selfconcepts and views of their professional role as teachers (Hativa \& Goodyear, 2002; Samuelowicz \& Bain, 2001). Finally, it is recognised that teaching is impacted by the personal aims and goals teachers pursue in their teaching (Hativa \& Goodyear, 2002).

In line with recent developments described in the educational literature, Korthagen introduced a model for teacher reflection which incorporates these various aspects of teacher functioning (figure 4.1) (Korthagen, 2004). 


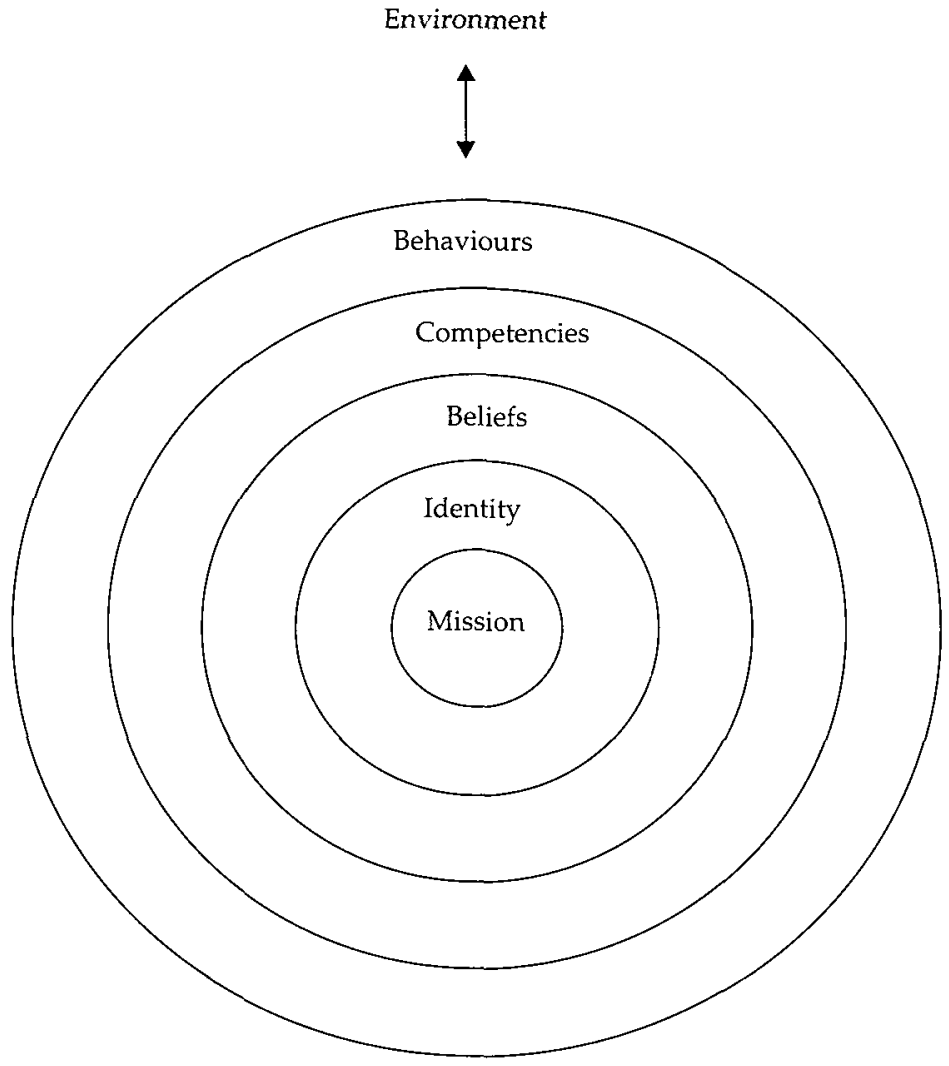

Figure 4.1. Korthagen's aspects of teacher functioning as a framework for reflection on teacher functioning (Korthagen, 2004, p. 80)

Some of the aspects in the model are generally accepted as relevant parts of the teaching context, such as the environment, behaviors or performance and competencies. Other aspects, such as beliefs, professional identity and mission are relatively new as subjects of attention for reflective teachers. 'Beliefs' relates to teachers' perceptions and ideas about students, learning, et cetera; professional identity refers to teachers' approach to teaching, their self-concepts and, more specifically, how they perceive themselves as teachers and the teacher role in general. Finally, mission is concerned with the aims and goals teachers pursue in teaching. It relates to the ideas that have led a person to become a teacher and to the broader goals teachers want to attain in their work. It should be noted that the inner aspects included in the model, i.e. beliefs, professional identity and 
mission are related to the individual teacher as a unique person. These inner aspects are less concrete and easy to observe than the outer aspects of the model. They also tend to remain implicit and not enter into teachers' conscious awareness. Nevertheless, both the inner and outer aspects have a major impact on teacher performance and development and thus can be regarded as targets for change. For example, a teacher who sees the role of the teacher predominantly as that of information provider might extend his/her role perception by additionally incorporating the role of facilitator of student learning (professional identity). This change may be triggered by a change in another aspect, for example views about student learning (beliefs), or the realisation that the ultimate goal in teaching is not to provide information, but rather to foster students understanding of a subject (mission). Thus, all aspects of teacher functioning, both the inner and the outer aspects, are important and interrelated. To improve and develop as a teacher, teachers should be conscious of all aspects that affect their functioning. This means that all these aspects should be subject of reflection.

We explored the use of a portfolio aimed at enhancing reflection by teachers in order to identify aspects on which teachers reflect in their professional work. We used Korthagen's model to analyse teachers' reflections, because it comprises a variety of both inner and outer aspects, rendering it a useful tool to help teachers, teacher trainers and coaches to discover which aspects of teacher functioning are relevant subjects for conversations about teaching portfolios within the context of professional development. Because Korthagen's model is relatively new, the aim was to give illustrative examples of how teachers reflect on various aspects of their functioning included in the model.

\section{Methods}

\section{Context of the study}

At Maastricht Medical School, we developed a teaching portfolio intended to stimulate teachers to reflect on the aspects of teaching included in Korthagen's model.

In order to structure the portfolio, we asked teachers to focus on different teacher roles: i.e. those of the person as a teacher, expert on content knowledge, facilitator of learning processes, organiser and scholar/lifelong learner (Tigelaar et al., 2004). The role the person as a teacher is related to the inner aspects of teacher functioning in Korthagen's model, i.e.: beliefs, identity, and mission. The other teacher roles are related to competencies. 


\section{Participants}

The participants in this study were five experienced teachers at Maastricht Medical School. They were selected at the suggestions of the chairman of the Department of Educational Development and Research and the scientific director of the Institute for Medical Education. Participants had to meet the following criteria: a manifest interest in teaching as evidenced by teaching activities and willingness to participate in professional development as a teacher motivated by the wish to pursue a teaching career. The chairs of the prospective participants' departments were consulted and participants were invited to take part in the study.

\section{Instruments}

In this study, all the written portfolio assignments were approached as reflections on teacher functioning. In order to gain insight into the portfolio process, we collected the teachers' final portfolio assignments as well as data about the process of portfolio construction. In this way, we obtained portfolio data comprising written portfolio assignments and final reflective portfolio assignments. Firstly, the teachers were asked to describe the course of their teaching career. They were also asked to describe critical incidents in their development as a teacher, set learning goals, select artefacts in evidence of their teaching activities, compose a profile of a good teacher and reflect on that. The final assignment required them to compose a reflective portfolio, using the previous assignments as points of departure. The assignments were intended to stimulate reflection on all aspects of teacher functioning as defined in Korthagen's model. However, the critical incidents assignment was focused on the environment, behaviour, and competencies. Table 4.1 presents brief descriptions of the assignments.

\section{Analysis}

The analysis of individual teachers' completed assignments and reflections included in the final portfolios was aimed at identifying reflections on the different aspects of teacher functioning in Korthagen's model (Patton, 1990; Korthagen, 2004). For the analysis of the written portfolio documents we used a top down strategy consisting of five phases (Miles \& Huberman, 1994). The different categories to which reflections were assigned in the analysis were the aspects of teacher functioning in Korthagen's model. In the first phase, all the assignments were read to obtain a broad view of how they might be categorised. In the second phase, the assignments were read again and different fragments were distinguished according to the rule that a new fragment was found as soon as there was reason to use a different category label. 
Table 4.1. Short description of portfolio assignments

\begin{tabular}{|c|c|}
\hline Assignment & Short description \\
\hline Time line & $\begin{array}{l}\text { Describe experiences from your career as a teacher; mention both high and low } \\
\text { points. }\end{array}$ \\
\hline Critical event & Describe a difficult situation in your teaching career. \\
\hline Learning goals & $\begin{array}{l}\text { Analyse teaching situations for each role that require improvement; suggest } \\
\text { alternatives }\end{array}$ \\
\hline Evidence & $\begin{array}{l}\text { Provide evidence for each role and answer the questions: What is it? Why did you } \\
\text { choose it? What does it prove? }\end{array}$ \\
\hline $\begin{array}{l}\text { Competency } \\
\text { profile }\end{array}$ & $\begin{array}{l}\text { Design a competency profile for a teaching position you would like to fulfil, taking } \\
\text { the five roles as starting points, and analyse your teaching performance on the basis } \\
\text { of this profile. }\end{array}$ \\
\hline $\begin{array}{l}\text { Final portfolio } \\
\text { assignment }\end{array}$ & $\begin{array}{l}\text { The final portfolio should contain: curriculum vitae, analysis of teaching performance } \\
\text { for each role, evidence, conclusions and plans for further action. }\end{array}$ \\
\hline
\end{tabular}

This initial labelling was performed by the first author. In the third phase, examples of the initial labelling were discussed by the first, second, and third authors to enhance the quality of the analysis. This discussion resulted in cues for recognizing and labelling fragments to a certain category. Fourthly, in order to improve internal validity, we triangulated the results of the analyses of the different assignments (Miles \& Huberman, 1994; Patton, 1990; Yin, 1994). In the fifth phase, we selected the most illustrative examples of teachers' reflections on the different aspects of teacher functioning.

\section{Results}

The analysis yielded examples of reflections on all aspects of Korthagen's model, although reflections on competencies proved easiest to identify. We present cues for recognizing and labeilling fragments to a certain category as well as illustrative examples of reflections on each of the aspects of teacher functioning.

\section{Environment}

Teachers' reflections on their working environment revealed both enabling and disabling factors. Institutional characteristics and issues related to facilities and student input are examples of aspects in the environment that can facilitate or constrain teaching.

"We concluded that I'm currently taking on a lot of tasks. This is due to the huge staff shortage in our department. As one of the senior members of staff I find that 
many demands are made on my time. Unfortunately, this often goes at the expense of teaching."

"This year one of the groups I facilitated questioned whether the group meetings were worthwhile. They enjoyed the contacts with simulated patients and they saw the importance of these contacts, but they thought that (too) little added value was provided by both the discussions of these contacts in the group sessions and communication skill training."

"I assumed that a computer would be provided in the lecture hall, because I had prepared a power point presentation and had spent quite a lot of time preparing that. Well, it turned out there was no computer. And no assistance either. There wasn't even a telephone nearby. So, I could not start the lecture."

\section{Behaviours}

Reflections on performance or behaviours were often related to concrete situations and to teachers' responses to influences from the environment. These reflections were characterised by the frequent use of verbs.

"Remaining calm and trying to get the students to quiet down (sometimes raising my voice). Sometimes lowering my voice to make it difficult for students to hear what I'm saying. When I do that students start tackling each other about their conduct."

"When I feel that my message is not getting across, I keep trying to find ways to explain things more clearly."

"I have even developed my own system in which I first let students talk about a subject and then try to steer them into a certain direction by asking all sorts of questions. Finally, I tell them about my own experiences in practice and try to make them understand the difference between theory, which is often quite straightforward, and the complexities of real practice."

\section{Competencies}

When reflecting on their competencies, teachers often use terms like 'I am able to ...', 'I am ...', referring to the things they would be able to do.

"My lectures generally get good ratings. It is my impression that I'm quite convincing and I have managed to build on that in the course of time."

"I am able to make students the centre of attention and I can give good supervision within the undergraduate curriculum. I think I need to know more about group 
processes in order to be better able to supervise students, especially more advanced and mature students."

"I think that my main strength lies in encouraging students to do research. Pointing them in the right direction."

\section{Beliefs}

Reflections on beliefs are often formulated in terms of 'I think ...', 'In my opinion ...', 'I am convinced ...'. These reflections are generally not so much related to specific situations but refer to teaching in general, as is reflected by terms like 'most', 'in general'.

"I find that students are generally eager to learn and prepared to take on extra work. Often more so than I would have thought. For instance, when additional teaching was introduced in our department, I asked students to prepare a case to present to their colleagues using a picture with additional information about signs and symptoms. I am often surprised at how much time they spend on that. Occasionally, I do find that students fail to appreciate how busy we are as clinicians."

"In principle, I'm convinced that students are responsible for their own learning, but in practice I find it difficult to leave the responsibility with them."

"In my view problems should not be brought to a head when it is impossible to work constructively with colleagues. When this happens, it is probably better to ask for help from a colleague and this should not be seen as a defeat."

\section{Professional identity}

Reflections on professional identity relate to teachers' approach to teaching and how they perceive the role of the teacher. Teachers often use the word 'self' and reflections on professional identity tend to be even more general than those on beliefs, as is evidenced by the frequent use of the word 'always'.

"I always try to treat students more or less as equals, rather amicably. However, I do let them know that I am the one with the most knowledge and that it is up to them to try and extract that knowledge from me. That means that whenever possible I try to work interactively and not from an old-fashioned teacher student pattern."

"I see my role as a teacher primarily as a facilitating one. I try to be open to students and stimulate them to become more and more independent."

"I treat students as I want to be treated myself: openly, honestly, on an equal footing. I want to lend them a helping hand." 


\section{Mission}

When reflecting on the aspect of 'mission', teachers talk about the ultimate goals they pursue in teaching. These reflections are often highly generalised and contain a lot of superlatives, such as 'most important', 'most inspiring'.

"I hope that we have developed a dermatology course that will enhance students knowledge of skin diseases. At the end of the day I think that's one of my main goals in teaching students."

"One of the most enjoyable and motivating aspects of my work as a teacher is every time when I see the penny drop for students."

"Because I have profited a lot from the communication skill training I was given and have learned that communication skills are of vital importance for the doctor patient relationship, I'm very keen to heighten students' motivation for communication skill training."

\section{Conclusions}

This study was aimed at exploring how a portfolio stimulates teachers to reflect on various aspects of their functioning as teachers. The study was not intended to provide quantitative data about teachers' reflections, but rather to shed light on the ways in which teachers reflect on various aspects of their functioning. The qualitative analysis of the portfolio assignments yielded examples of all aspects of teacher functioning included in Korthagen's model, albeit that examples of reflection on competencies were easiest to find. This may be attributable to our attempts to structure the portfolio by asking the teachers to focus on different teaching roles, i.e. those of the person as a teacher, expert on content knowledge, facilitator of learning processes, organiser and scholar/lifelong learner (Tigelaar et al., 2004). Being asked to think in terms of these roles, the teachers may have been stimulated to focus on what they might be able to do, i.e. their competencies. Another explanation might be that teachers find it safer to reflect on the outer aspects of their functioning than on the inner aspects, which include motivations, feelings, thoughts and the unique personality of the teacher as an individual. Moreover, being deeply rooted in the teacher's personality and often remaining implicit, the inner aspects of teacher functioning may be more difficult to raise to teachers' awareness. More time might be needed to stimulate teachers to reflect on these inner aspects of their functioning. However, we did identify examples of reflections on aspects like beliefs, identity and mission. The examples of reflections on inner aspects of teacher functioning that we found illustrate important issues with regard to teacher functioning and development, including teachers' ideas about students 
and student learning, their role perceptions and reasons for wanting to be a teacher. These examples confirm the added value of the inclusion of these inner aspects of Korthagen's (2004) model of reflection on teaching.

The main limitation of this study is the small group of participants. For generalisable results a larger study population will be needed. In addition, generalisability of the study is reduced by the selection criteria of this study, which made recruitments from among the best teachers. A second shortcoming was the qualitative data analysis. A larger group of participants would have enabled a more thorough investigation with an additional cross-case analysis comparing different individual portfolio assignments and grouping them together by category so as to reveal patterns (Miles \& Huberman, 1994; Yin, 1994). Third, the results show that it was difficult to unambiguously categorise the fragments and make distinctions between the various aspects because they are interrelated.

Despite these limitations, we believe the results offer practical suggestions for teacher training and coaching. Firstly, the results appear to clearly indicate that the portfolio is a useful tool to stimulate teachers to reflect on different aspects of teaching. The portfolio assignments proved helpful in supporting the process of portfolio construction and they provided cues for teachers to gain insight into their own learning processes and professional development (Darling, 2001; Loughran \& Corrigan, 1995). Secondly, this study might help teachers and their trainers and coaches to recognise different aspects of teacher functioning when discussing portfolios for professional development purposes. The outcomes of portfolio assignments may provide useful starting points for portfolio meetings, courses and discussions to deepen teachers' reflections and stimulate their professional development, which would enhance the value of the teaching portfolio (Wolf \& Dietz, 1998). Factors that are out with the control of the individual teacher, for example influences to the environment which lay beyond the teacher's power, should not be the main focus on in these conversations. Rather, these conversations should be focused on aspects of teacher functioning that are in with the control of the individual teacher, because the main purpose is to promote change, improvements and development.

More research will be needed to determine ways to adapt the assignments so as to stimulate reflection on the inner aspects of teaching and raise teachers' awareness of their personal beliefs, professional identity and mission as a teacher. In addition to the assignments, other methods might be developed that encourage reflections on the inner aspects, something that was also acknowledged by Korthagen (2004). Thirdly, interactions with peers and coaches during the process of portfolio construction and their effects on teachers' reflections should be researched. Finally, it would be interesting to focus not only on the content of teachers' reflections, i.e. what teachers reflect on, but also on the depth of teachers' reflection processes, i.e.: the extent to which 
teachers move beyond the mere description of events to try and find possible reasons for and relationships between events or consider different opinions (Mansvelder-Longayroux et al., 2002). Finally, since reflection is not a goal in itself, but is rather supposed to stimulate teachers to change and improvement, further research should focus on examples of how the reflective process has changed various aspects of their teaching.

\section{Practice points}

- Teaching portfolios are frequently used to stimulate reflections on teaching. Reflection frameworks often emphasise behaviours and competencies. However, the environment, beliefs, professional identity and mission are also important subjects for reflection.

- This study provides illustrative examples of how teachers reflect on various aspects of their functioning. Reflection may further recognition of these aspects so that they can be used in portfolio conversations aimed at professional development.

- Further ways to stimulate reflection on teacher beliefs, professional identity and mission should be sought. Apart from the content of reflections, teachers' reflection processes and the effects of portfolio meetings with peers and coaches should be researched.

\section{References}

Anderson, R., \& DeMeulle, L. (1998). Portfolio use in twenty-four teacher education programs. Teacher Education Quarterly, 25(1), 23-32.

Bartell, C., Kaye, C., \& Morin, J. A. (1998). Teaching portfolios in teacher education. Teacher Education Quarterly, 25(1), 5-8.

Bird, T. (1990). The schoolteacher's portfolio: an essay on possibilities. In J. Millman \& L. E. DarlingHammond (Eds.), The new handbook of teacher evaluation. Assessing elementary and secondary schoolteachers (pp. 241-256). Newbury Park: CA: Corwin Press Inc.

Darling, F. L. (2001). Portfolio as practice: the narratives of emerging teachers. Teaching and Teacher Education, 17, 107-121.

Darling-Hammond, L., \& Snyder, J. (2000). Authentic assessment of teaching in context. Teaching and Teacher Education, 16, 523-545.

Davis, M. H., Friedman Ben David, M., Harden, R. M., Howie, P., Ker, J., McGhee, C., et al. (2001). Portfolio assessment in medical students' final examinations. Medical teacher, 23(4), 357-366.

Driessen, E. W., Van Tartwijk, J., Vermunt, J., \& Van der Vleuten, C. P. M. (2003). Use of portfolios in early undergraduate medical training. Medical teacher, 25(1), 18-23.

Friedman Ben David, M., Davis, M. H., Harden, R. M., Howie, P. W., Ker, J., \& Pippard, M. J. (2001). AMEE Medical Education Guide N. 24: Portfolios as a method of student assessment. Medical teacher, 23(6), 535-551. 
Gordon, J. (2003). Assessing students' personal and professional development using portfolios and interviews. Medical education, 37, 335-340.

Hativa, N., \& Goodyear, P. (2002). Research on teacher thinking, beliefs, and knowledge in higher education: foundations, status and prospects. In N. Hativa \& P. Goodyear (Eds.), Teacher thinking, beliefs and knowledge in higher education (pp. 335-359). Dordrecht: Kluwer Academic Publishers.

Kember, D. (1997). A reconceptualisation of the research into university academics' conceptions of teaching. Learning and Instruction, 7(3), 255-275.

Kember, D., \& Kwan, K. (2002). Lecturers' approaches to teaching and their relationship to conceptions of good teaching. In N. Hativa \& P. Goodyear (Eds.), Teacher thinking, beliefs and knowledge in higher education (pp. 210-239). Dordrecht: Kluwer Academic Publishers.

Korthagen, F. A. J. (2004). In search of the essence of a good teacher: towards a more holistic approach in teacher education. Teaching and Teacher Education, 20, 77-97.

Loughran, J., \& Corrigan, D. (1995). Teaching portfolios: a strategy for developing learning and teaching in preservice education. Teaching and Teacher Education, 11(6), 565-577.

Mansvelder-Longayroux, D., Beijaard, D., \& Verloop, N. (2002). Het portfolio als reflectieinstrument voor docenten-in-opleiding. Pedagogische Studiën, 79(4), 269-286.

Martin, E., Prosser, M., Trigwell, K., Ramsden, P., \& Benjamin, J. (2000). What university teachers teach and how they teach it. Instructional Science, 28, 387-412.

Mathers, N. J., Challis, M., Howe, A. C., \& Field, N. J. (1999). Portfolios in continuing medical education - effective and efficient? Medical education, 33, 521-530.

Miles, M. B., \& Huberman, A. M. (1994). Qualitative data analysis. London: Sage.

Patton, M. Q. (1990). Qualitative Evaluation and Research Methods. Newbury Park, California: SAGE Publications Inc.

Ramsden, P. (1992). Learning to teach in higher education. New York: Routledge.

Rees, C., \& Sheard, C. (2004). Undergraduate medical students' views about a reflective portfolio assessment of their communication skills learning. Medical education, 38, 125-128.

Samuelowicz, K., \& Bain, J. D. (2001). Revisiting academics' beliefs about teaching and learning. Higher Education, 41, 299-325.

Snadden, D. (1999). Portfolios - attempting to measure the unmeasurable? Medical education, 33, 478479.

Tigelaar, E. H., Dolmans, D. H. J. M., Wolfhagen, H. A. P., \& Van der Vleuten, C. P. M. (2004). The development and validation of a framework for teaching competencies in higher education. Higher Education, 48, 253-268.

Van Tartwijk, J., Driessen, E. W., \& Rubens, W. (2004). Functions of Electronic Portfolios in Higher Education. In P. Boezerooy \& P. Gorissen (Eds.), Dutch E-Learning in Europe (pp. 8-10). Utrecht: SURF.

Webb, C., Gray, M. A., Jasper, M. A., McCullan, M., \& Scholes, J. (2002). Models of portfolios. Medical Education, 36, 897-898.

Wolf, K., \& Dietz, M. (1998). Teaching portfolios; Purposes and Possibilities. Teacher Education Quarterly, 25(1), 9-22.

Yin, R. K. (1994). Case study research: design and methods. Beverly Hills: CA.: Sage. 
Zeichner, K., \& Wray, S. (2001). The teaching portfolio in US teacher education programs: what we know and what we need to know. Teaching and Teacher Education, 17, 613-621. 


\section{5 \\ Participants' opinions about the usefulness of a teaching portfolio 4}

Abstract. Whether teaching portfolios achieve their aim of stimulating teachers' professional development is favourably affected by a balanced structure and effective social interactions, such as coaching. We explored teachers' experiences with a teaching portfolio that was structured by teaching roles, portfolio assignments and conversation protocols. The related social interactions consisted of meetings with peers and personal coaches. Teachers' and coaches' opinions were sought about the benefits and the enabling and disabling factors of the portfolio structure and the social interactions.

Five teachers and their personal coaches were individually interviewed about their experiences with the portfolio. Protocols were analysed using a topdown strategy.

The teaching roles were helpful in analysing teaching, but the assignments and the conversation protocols were too detailed and directive. The social interactions were perceived as very valuable for professional development, particularly the meetings with personal coaches.

The portfolio structure and social interactions, especially personal coaching, appeared to be helpful for teachers in analysing their teaching practice. The assignments and protocols, however, were too detailed and directive. This may be resolved by using assignments and conversation protocols more flexibly and enabling adjustment to personal learning needs. The high appreciation of personal coaching might be related to the freedom for teachers to choose their own coach. The results can be used as guidelines for portfolio designers as to how to achieve a balanced structure and effective social interactions and how these might be combined to increase the benefits to teachers from working with a portfolio.

4 This chapter has been accepted for publication in Medical Education as: Tigelaar, E.H., Dolmans, D.H.J.M., De Grave, W.S., Wolfhagen, H.A.P., \& Van der Vleuten, C.P.M. Participants' opinions about the usefulness of a teaching portfolio. 


\section{Introduction}

Portfolios are said to be valuable for professional development, because they encourage active and self-directed learning and reflective practice (Snadden, 1999; Eraut, 1994; Driessen, Van Tartwijk, Vermunt \& Van der Vleuten, 2003; McMullan, Endacott, Gray, Jasper, Miller, Scholes et al., 2003; Mathers, Challis, Howe \& Field, 1999; Gordon, 2003). Like other professionals, teachers continue to learn throughout their career and they actively construct their own knowledge by interpreting events on the basis of existing knowledge, beliefs and dispositions and by learning from experiences (Rees \& Sheard, 2004). Portfolios are increasingly being used in teacher education to stimulate individual teachers' professional growth and to realise improvements in the teaching profession in general (Bird, 1990; Zeichner \& Wray, 2001). It is thought that portfolios stimulate teachers to think more carefully about their teaching and subject matter (Anderson \& DeMeulle, 1998; Bartell, Kaye \& Morin, 1998; Darling-Hammond \& Snyder, 2000), influence classroom practices, increase teachers' self-confidence as teachers and enlighten teachers about what is expected of them as professionals (Moss, Schutz \& Collins, 1998; Delandshere \& Arens, 2003).

When portfolios are actually introduced, however, the potential benefits often fail to materialise fully and immediately (Darling, 2001; Pearson \& Heywood, 2004). Effective portfolio learning is predicated on a well-balanced portfolio structure Driessen, Van Tartwijk, Vermunt \& Van der Vleuten, 2003; Darling, 2001; Grant \& Dornan, 2001) and effective social interaction around the portfolio process (Darling, 2001; Wolf \& Dietz, 1998). Structure can be enhanced by offering portfolio makers illustrative portfolio samples or a portfolio template. The degree of structuring may vary from highly directive and detailed instructions to total freedom for portfolio makers (Zeichner \& Wray, 2001; Wolf \& Dietz, 1998). When portfolio instructions are highly directive and detailed, portfolio makers are limited in their freedom to organize their portfolio and to choose evidence. Evidence to be included in a portfolio may vary from a prescribed limited set of specific samples of teachers' work to an eclectic collection of evidential materials. Although portfolio makers should have an idea of what is expected of them, instructions should not prevent them from pursuing personal learning goals (Darling, 2001; Tigelaar, Dolmans, Wolfhagen \& Van der Vleuten, 2004a). Thus a careful balance must be struck between prescribing every detail of the portfolio and leaving it completely open-ended.

Apart from structure, social interaction is thought to facilitate portfolio learning. Deeper learning is expected to be fostered when teachers discuss their portfolios with colleagues and others (Freidus, 1998). In professional development, coaching is a popular form of interaction, because it promotes reflection and the sharing of ideas and thereby helps professionals to improve 
and refine their functioning (Ackland, 1991; Joyce \& Showers, 1995; Gallacher, 1997; Thijs \& Van den Berg, 2002). Coaching can be done by peers or colleagues and the process is usually structured and systematic. Confidentiality must be guaranteed and the role of coach and evaluator should not be combined in one person. Coaching differs from mentoring, in that the latter presupposes a relationship in which an experienced, more knowledgeable teacher (mentor) offers support and guidance to a less experienced teacher to facilitate that teacher's education and development. Different models of coaching (Ackland, 1991) are: team coaching, one-on-one coaching and coaching targeted on skills development or on decision making. Coaching cycles, i.e. series of coaching meetings, typically focus on analysis of teachers' performance in practice (Gallacher, 1997). Another function of coaching is to provide support, encouragement, feedback and to stimulate reflection on performance, culminating in plans for improving professional practice. In summary, the potential benefits of coaching include support and reassurance from colleagues, an incentive to collaborate by exchanging ideas and experiences, improved professional practice and empowerment for professional development.

Whilst it is clear that structure and social interaction determine the usefulness of teaching portfolios, it is less clear how to determine and achieve the most effective mix of these ingredients. In a previous study, we presented a teaching portfolio procedure (Tigelaar, Dolmans, Wolfhagen \& Van der Vleuten, 2004a) designed to facilitate teachers' professional development through a combination of well-balanced structure and social interactions. In this study, we asked teachers and coaches who had worked with the portfolio about the benefits and the enabling and disabling factors related to the structure and social interaction incorporated into the portfolio. We also asked them whether the portfolio process as a whole was a good instrument for fostering teachers' professional development and if it was suitable for summative purposes, i.e.: career decisions. Thus, the present study is aimed at identifying which factors enable and disable the extent to which this teaching portfolio stimulates teachers' professional development and especially participants' opinions about the portfolio's structure and social interactions in this respect. From the results of this study guidelines may be derived for portfolio designers who are in charge of the development, organisation and planning of portfolio processes.

\section{Methods}

\section{Context of the study}

The purpose of the teaching portfolio was primarily formative, although the option of future summative use was kept open. Structure was provided by asking the teachers to organise the portfolio according to the following roles of 
teachers: (Tigelaar, Dolmans, Wolfhagen \& Van der Vleuten, 2004b) the person as a teacher, expert on content knowledge, facilitator of learning processes, organiser and scholar/lifelong learner. In addition, structure was offered through six assignments: describe your teaching career history; describe critical incidents in your development as a teacher; design personal learning goals; select evidential materials; compose a profile of a good teacher; and compile a reflective portfolio. After each assignment the teachers alternately engaged in one of two types of social interactions (Table 5.1). The social interactions were intended to stimulate teachers' reflections on their functioning. In all, the social interactions comprised six meetings: three peer meetings with colleagues who were also working on a portfolio, facilitated by a teacher trainer and three meetings with a personal coach, who was an experienced teacher well qualified to provide support and feedback on teaching. These social interactions were expected to reinforce the effects of the assignments through support and feedback, in-depth analysis, suggestions for improving practice, encouragement for teachers to reflect on their perceptions and decisions in order to better understand their own teaching practice. The peer meetings were structured according to a systematic problem solving approach with minimal guidance by the facilitator. Global conversation protocols, i.e. guidelines for the dialogues between coaches and teachers, were used to structure the meetings with personal coaches. Table 5.1 shows the schedule of the portfolio process. The total time investment for participants was estimated at fifty hours.

\section{Participants}

Five experienced teachers and their personal coaches were involved in the study, all medical doctors working at Maastricht Medical School. The teachers were selected for participation in the study by the chair of the Department of Educational Development and Research and the scientific director of the Institute for Medical Education on the basis of a proven interest in teaching, willingness to engage in professional development as a teacher and the intention to pursue a teaching career. After permission was obtained from the chairs of the teachers' departments, the teachers were invited to participate in the study. All teachers agreed to participate. For two teachers, teaching was their primary task and the others combined clinical work and teaching. Teaching experience varied from seven to thirty years and from tutoring small groups of students to organising and coordinating new educational programmes. The teachers were free to choose their own personal coach, but for confidentiality reasons and because the role of coach and evaluator should not be combined in one person, colleagues or teachers' department chairs were not acceptable. 
Table 5.1. Schedule of the portfolio process

\begin{tabular}{ll}
\hline Activity & Short description \\
\hline Teaching history assignment & $\begin{array}{l}\text { Describe experiences from your career as a teacher; mention both } \\
\text { high and low points }\end{array}$ \\
$\begin{array}{ll}\text { First meeting with personal coach } \\
\text { (1.5 hours) }\end{array}$ & $\begin{array}{l}\text { Goal: getting acquainted, becoming aware of motivations; } \\
\text { exploration of strong points and areas in need of improvement }\end{array}$ \\
Critical events assignment & Describe a difficult situation in your teaching career \\
First peer meeting (1.5 hours) & $\begin{array}{l}\text { Goal: getting acquainted, providing feedback and advice about } \\
\text { critical events, learning from others }\end{array}$
\end{tabular}

Learning goals assignment

Analyse teaching situations for each role that require improvement; suggest alternatives

Second meeting with personal coach (1.5 hours)

Goal: making situations more concrete and becoming aware of key aspects of situations in order to set learning goals

Evidential materials assignment Provide evidence for each role and answer the questions: what is it? Why did you choose it? What does it prove?

Second peer meeting (1.5 hours) Goal: share ideas and feedback on selecting evidential materials

Competency profile assignment Design a competency profile for a teaching position you would like to fulfil, taking the five roles as starting points, and analyse your teaching performance on the basis of this profile

Third peer meeting (1.5 hours) Goal: Providing feedback and advice on critical events, learning from others

Final portfolio assignment The final portfolio should contain: curriculum vitae, analysis of teaching performance for each role, evidence, conclusions and plans for further action

Third meeting with personal coach Goal: more in depth analyses, making conclusions and action plans (1.5 hours) more concrete

We opted for coaching instead of mentoring because all participants were experienced teachers. Other selection criteria for coaches were: an interest and experience in teaching, coaching skills and familiarity with the Medical School organisation. The selected coaches met the criteria and agreed to participate. The teachers and their coaches were interviewed after they had completed the portfolio process. 


\section{Instrument}

The first author (DT) conducted semi-structured interviews with all participants using an open-ended interview protocol based on the general interview guide approach (Patton, 1990). The interviews lasted approximately 90 minutes. The questions in the interview guides focused on two themes: portfolio structure and the social interactions within the portfolio process. The questions about structure concerned the teaching roles, the assignments and the conversation protocols. The questions about social interaction focused on the meetings with colleagues and personal coaches. The questions focused on perceived benefits so as to determine whether the portfolio had a favourable effect on teachers' professional growth. Illustrative questions are provided in Table 5.2.

Table 5.2. Illustrative questions from the interview guide

\begin{tabular}{ll}
\hline Dimension & Questions \\
\hline Portfolio structure & For teachers: \\
& How did you experience working with the teaching roles? \\
& How did you benefit from doing the assignments and can you elaborate on \\
specific aspects that contributed to these benefits? & For coaches: \\
& Did you find the global conversation protocols clear and helpful? \\
& For teachers \\
& Did you experience the peer meetings and personal conversations with \\
your coach as significant and what benefits did you perceive? & For coaches \\
& Do you think that your personal conversations with the teacher added to \\
the value of the assignments? & What do you think was particularly beneficial to the teacher?
\end{tabular}

Finally, the interviewees were asked te comment on the portfolio process, on its implementation as an instrument for professional development and on the suitability of the portfolio for summative purposes.

\section{Analysis}

The interviews were recorded on audiotape and analysed in four phases. First, the first author summarised each interviewee's responses. Second, interview content was analysed according to a top-down strategy (Miles \& Huberman, 1994a; Miles \& Huberman, 1994b). The analysis identified for both structure and social interactions the benefits, enabling and disabling factors and suggestions for improvement with respect to teachers' professional growth. Third, the main points made by the interviewees about structure and social interaction were listed and illustrative citations were marked. In order to ensure the quality of the analysis, the first three authors independently conducted steps two and 
three of the analysis. Fourth, after the results of these analyses proved to be comparable, the three authors reached consensus on which citations were most illustrative of participants' statements about portfolio structure, social interactions and the general comments on the portfolio process and its implementation.

\section{Results}

\section{Portfolio structure}

Both teachers and coaches said they felt an affinity with the teaching roles and had found them helpful in differentiating between teaching activities and thus in structuring the portfolio. The teachers said the assignments had helped them to analyse their teaching performance in a structured and critical fashion and to look at themselves from different perspectives. The teaching history assignment met with the greatest appreciation. Taking time to write down their reflections made the teachers more aware of what they enjoyed about teaching, their strengths and areas in need of improvement. Both teachers and coaches thought the assignments provided good starting points for discussions with peers and personal coaches. On the negative side, however, it was said that the assignments, the one about 'learning goals' in particular, were too detailed and directive. Most coaches expressed a preference for more global conversation protocols with more room to pursue individual teachers' needs and learning goals.

"Doing the assignments gave me much satisfaction. It's amazing how much I have done over the years and how much knowledge and experience I have gained which I can use. There are details that can be improved. (...) Other insights, less concrete, which result from thinking things over. There is a shift in how you look at things. When you stop and look, your perception may change" (T5)

"The assignments could have been more simple and less structured; the results would have been the same. There were too many questions and they were too detailed. They should be more global and you should have more freedom" (T3)

"It's my opinion that the teacher should have a lot of input in coaching. Frameworks are needed as guidelines. Protocols may be helpful, but in this case they were a bit too directive" (C1)

\section{Social interaction}

Most of the teachers found the peer meetings valuable, because sharing experiences, hearing different viewpoints, thinking along with others and 
receiving feedback made them take a fresh look at their own teaching and in some cases stimulated them to improve practice. They wanted more time for the peer meetings to give all participants a chance to contribute their experiences.

The meetings with the coach were highly appreciated by both teachers and coaches. The teachers were particularly enthusiastic about the individual focus and the feedback tailored to their personal situation. The coaches helped the teachers analyse their functioning more concretely and thoroughly by looking at their reflections from different perspectives, putting things differently, holding up a mirror and helping teachers to arrive at more concrete and detailed reflections and plans for action.

\section{Peer meetings}

"Sharing experiences with others was also important. Others have the same problems. Solutions that others have used, you can learn from those. Sometimes you also learn from the feedback you receive from others. And helping others think about their problems also gave me new insights. (...) There were also direct effects. For instance, I used the material of the second peer meeting to design a student evaluation. I have also used the evaluation in the peer group in restructuring a training programme". (T5)

Meetings with personal coach

"I see the assignments as finger exercises. In depth analysis is only achieved in discussions with your coach and with peers. (...) The most useful aspect of coaching was that a mirror is held up to you and that you stop and think about things. The personal aspect in that. My coach mainly advised. (...) He asked again and again: what concrete steps are you going to take". (T1)

"The teacher and I came to several surprising conclusions, which resulted in plans for action. For example: in my role as coach I confronted him with contradictory aspects of his teaching practice. The teacher's response was: I have never looked at it that way. This resulted in plans for action which led to concrete results. The added value mostly resided in the different perspective I was able to offer and in setting concrete goals. It's easier to achieve those when you have to report to someone else" (C3)

"Making things concrete, to my mind that's the most important part of what a coach does. How important is something to you, what exactly do you like? How exactly did you do that? Also indicate what you don't want. In many cases what you want to achieve is rather broad and what actually happens is determined by what you don't want. I think the teacher was mainly helped by my putting things in perspective. 
And formulating clear priorities. More specifically, reflecting on past actions and what he liked about them. And a clearer view of where he wants to go" (C5).

\section{General comments on working with the portfolio and portfolio implementation}

Although the portfolio process gave teachers a better insight into their functioning and areas for improvement, there was not enough time to actually use the feedback to change teaching practice, evaluate improvements and experience real development. Doing the assignments, reflecting on teaching and working on the portfolio was a heavy workload for the teachers, the more so since reflecting on teaching was a highly absorbing process. Given the timeconsuming nature of the portfolio process, the participants recommended that the portfolio should only be used for those aspiring to a teaching career. They saw the portfolio as suitable for both formative and summative purposes, although more emphasis was placed on the formative goal.

"There wasn't enough time to make real progress on the themes I discussed. I have not been able to actually change my conduct." (T1)

"The thing is it takes a lot of time and discipline. It's an extra activity, something I have to do in my own free time (...). 50 hours is a realistic estimation of the total time investment. However, it's not just sitting down to do your assignment, writing things down and that's it. It's a process of reflection, you leave it for a while, in the meantime you think it over and then you continue. I spent at least 3 hours on each assignment, apart from giving it thought while not actually working on it." (T2)

"Still, the matter of formative versus summative is not a real issue. When you coach a teacher in his or her development, you do judge him or her: what's this teacher's potential? You form impressions. You should be honest: the portfolio is inevitably also summative, it has an assessment side to it. Perhaps it would be better to just clearly admit that. And to give clear criteria and explain how you judge someone." (C2)

\section{Discussion}

We evaluated whether a teaching portfolio was an effective instrument for teachers professional development by asking teachers and coaches to give their opinions about the enabling and disabling factors and the benefits associated with the structure and the social interactions incorporated in the portfolio process. The participants' general view was that the elements used to structure the portfolio, i.e. the teaching roles, assignments and conversation protocols were helpful in fostering teachers' professional development by stimulating 
them to analyse teaching performance. The perceived benefits included insight into what teachers like about teaching and identification of strengths and areas for improvement. Participants said that the teaching roles were helpful in differentiating between teaching activities and in structuring the portfolio. The assignments and conversation protocols, however, were criticised for being too detailed and directive. The social interactions were perceived as highly valuable. Perceived benefits from the meetings with peers and personal coaches included good support, feedback and different viewpoints and stimulation to improve teaching practice. The interactions with the personal coach in particular were applauded by the teachers. The participants commented that the portfolio process was mainly suitable for teachers wanting to pursue a teaching career, thereby supporting both the formative and summative functions of portfolios. However, if the portfolio is to be used for summative purposes, a trustworthy assessment procedure will have to be developed (Driessen, Van der Vleuten, Schuwirth, Van Tartwijk \& Vermunt, 2005; Tigelaar, Dolmans, Wolfhagen \& Van der Vleuten, In Press).

Disabling factors appeared to be the prescriptive phrasing of the assignments and conversation protocols and the heterogeneity of the participating teachers. The prescriptive phrasing of the assignments and conversation protocols may explain the perceived excess of detail and overly directive instructions. Furthermore, achieving an optimal alignment of portfolio structure and social interactions may have been complicated by the heterogeneity of the teachers, who differed in teaching experiences, background and teaching subjects. These differences may have influenced teachers' perceptions with regard to structure and social interactions. Moreover, the differences between the teachers' personalities and reflective abilities made it difficult to tailor structure and social interaction to their individual needs and to make the process supportive and challenging to all the teachers. More flexibility in the assignments and conversation protocols and more opportunities for adjustment to teachers' individual learning needs seems likely to offer the solution to the problem of the perceived rigidity of structure.

Enabling factors appeared to be the broadly defined teacher roles, which were perceived as helpful for differentiating between teaching activities, and the option for teachers to choose their own coaches. The positive appraisal of the conversations with the coaches may be due to this opportunity, which may have promoted supportive and satisfying teacher coach relationships.

The perceived benefits, i.e. insight into the pleasures of teaching, identification of strengths and areas for improvement, receiving support and feedback, different viewpoints and stimulation to improve teaching practice, indicate that structure and social interaction are of crucial importance for the effectiveness of the portfolio in stimulating teachers' reflection and professional development. Furthermore, the results show that social interactions are indispensable for the deepening effects of the assignments. In other words, 
social interactions intensify the processes that are stimulated by the assignments. The results with respect to the enabling and disabling factors and the perceived benefits for professional development, suggest that we are justified in concluding that the quality of the portfolio is reasonable.

The results are in accordance with findings reported in the literature. Difficulty in establishing a suitable portfolio structure, i.e. a clear description of what is expected without stifling teachers' initiatives to set personal learning goals, is frequently mentioned (Darling, 2001; Tigelaar, Dolmans, Wolfhagen \& Van der Vleuten, 2004a). The benefits from coaching as experienced by the teachers correspond with reported benefits from coaching programmes (Gallacher, 1997). In addition, the finding that the teachers were stimulated to analyse their teaching confirms that portfolios have the potential to encourage deeper thinking about teaching (Anderson \& DeMeulle, 1998; Bartell, Kaye \& Morin, 1998; Darling-Hammond \& Snyder, 2000).

This study shows how structure and social interactions can be systematically combined to enhance the benefits teachers derive from a portfolio. From the results of this study guidelines can be derived for designing portfolio processes that offer an effective combination of well-balanced structure and appropriate social interactions to facilitate teachers' professional development. First, the structure should not be overly restrictive and directive. Differentiated portfolio assignments and open-ended conversation protocols would offer flexibility in tailoring both interpretation and performance of assignments and the coaching process to teachers' personal needs. Second, rapport and a trusting teacher coach relationship are fostered when teachers choose their own personal coaches as was done in this study, although coaches must meet certain criteria, such as extensive experience in teaching and good coaching skills. Finally, there should be enough time for the teachers to experiment with and evaluate changes in teaching practice. Apart from these guidelines, it should be noted that achieving a well-balanced portfolio structure and appropriate social interactions is highly dependent on context and participants' characteristics. For this reason, we recommend that a portfolio should first be introduced on a small scale to enable fine-tuning of all the elements in the portfolio process, as was done in this study.

A limitation of this study is that the results are based on participants' perceptions. Future research should use direct observation of social interactions around portfolio construction. In-depth studies of these social interactions are needed as well as more research into the benefits of longitudinal portfolio processes.

\section{Key learning points}

What is already known. The realisation of the potential benefits of portfolios is favourably affected by a balanced portfolio structure and effective social 
interactions as part of the portfolio process. A good combination of a balanced structure and effective social interactions is difficult to achieve.

What this study adds. Portfolio structure should not be overly restrictive and directive. Portfolio assignments and conversation protocols should be adaptable to learners' personal needs and preferences. Coaching relationships are fostered when teachers can choose their own personal coach.

Suggestions for further research. In-depth studies into the social interactions around the portfolio process are needed. The benefits from longitudinal portfolio processes should also be studied.

\section{References}

Ackland R. (1991). A review of the peer coaching literature. Journal of Staff Development 12, 22-27.

Anderson R, DeMeulle L. (1998). Portfolio use in twenty-four teacher education programs. Teacher Education Quarterly 25(1), 23-32.

Bartell C., Kaye C., Morin J.A. (1998). Teaching portfolios in teacher education. Teacher Education Quarterly 25(1), 5-8.

Bird T. (1990). The schoolteacher's portfolio: an essay on possibilities. In: Millman J., DarlingHammond L.E. (Eds.), The new handbook of teacher evaluation. Assessing elementary and secondary schoolteachers. (pp. 241-256). Newbury Park: CA: Corwin Press Inc.

Darling F.L. (2001). Portfolio as practice: the narratives of emerging teachers. Teaching and Teacher Education 17, 107-121.

Darling-Hammond L., Snyder J. Authentic assessment of teaching in context. (2000). Teaching and Teacher Education 16, 523-545.

Delandshere G., Arens S.A. (2003). Examining the quality of the evidence in preservice teacher portfolios. Journal of Teacher Education 54(2), 57-73.

Driessen E.W., Van Tartwijk J., Vermunt J., Van der Vleuten C.P.M. (2003). Use of portfolios in early undergraduate medical training. Medical Teacher 25(1), 8-23.

Driessen E., Van der Vleuten C., Schuwirth L., Van Tartwijk J., \& Vermunt J. (2005). The use of qualitative research criteria for portfolio assessment as an alternative to reliability evaluation: a case study. Medical Education, 39(2), 214-20.

Eraut, M. (1994). Developing Professional Knowledge and Competence. London, Falmer Press.

Freidus H. Mentoring portfolio development. (1998). In: Lyons N, editor. With portfolio in hand: Validating the new teacher professionalism (pp. 51-68). New York, London: Teachers College Press.

Gallacher K. (1997). Supervision, mentoring and coaching. In: Winton P.J., McCollum J.A., Catlett C. (Eds.), Reforming personnel preparation in early intervention. Issues, Models, and Practical strategies (pp. 191-214). Baltimore, Maryland: Paul H. Brooks Publishing Co.

Gordon J. (2003). Assessing students' personal and professional development using portfolios and interviews. Medical Education 37, 335-40.

Grant G., Dornan T.L. (2001). What is a learning portfolio? Diabetic Medicine 18, 1-4. 
Joyce C., Showers B. (1995). Student Achievement through Staff Development: Fundamentals of School Renewal. New York: Longman.

Mathers N.J., Challis M., Howe A.C., Field N.J. (1999). Portfolios in continuing medical education effective and efficient? Medical Education 33, 521-30.

McMullan M., Endacott R., Gray M.A., Jasper M.A., Miller C.M.L., Scholes J., et al. (2003). Portfolios and assessment of competence: a review of the literature. Journal of Advanced Nursing 41 , 283-294.

Miles M.B., Huberman A.M. (1994a). Within-case Displays: Exploring and Describing. In: Miles MB, Huberman A.M. (Eds.), Qualitative Data Analysis. Thousand Oaks: Sage Publications.

Miles M.B., Huberman A.M. (1994b). Matrix Displays: Some rules of Thumb. In: Miles MB, Huberman A.M. (Eds.), Qualitative Data Analysis. Thousand Oaks: Sage publications.

Moss P.M., Schutz A.M., Collins K.M. (1998). An integrative approach to portfolio evaluation for teacher licensure. Journal of Personnel evaluation in education, 12(2), 139-161.

Patton M.Q. (1990). Qualitative Evaluation and Research Methods. Newbury Park, California: SAGE Publications Inc.

Pearson D.J., Heywood P. (2004). Portfolio use in general practice vocational training: a survey of GP registrars. Medical Education, 38, 87-95.

Rees C., Sheard C. (2004). Undergraduate medical students' views about a reflective portfolio assessment of their communication skills learning. Medical Education, 38, 125-28.

Snadden D. (1999). Portfolios - attempting to measure the unmeasurable? Medical Education 33, 478479.

Thijs A., Van den Berg E. (2002). Peer coaching as part of a professional development program for science teachers in Botswana. International Journal of Educational Development, 22, 55-68.

Tigelaar E.H., Dolmans D., Wolfhagen H.A.P., Van der Vleuten C.P.M. (2004a). Using a conceptual framework and the opinions of portfolio experts to develop a teaching portfolio prototype. Studies in Educational Evaluation, 30, 305-321.

Tigelaar E.H., Dolmans D.H.J.M., Wolfhagen H.A.P., Van der Vleuten C.P.M. (2004b). The development and validation of a framework for teaching competencies in higher education. Higher Education, 48, 253-268.

Tigelaar, E.H., Dolmans, D.H.J.M., Wolfhagen, H.A.P., \& Van der Vleuten, C.P.M. (In Press). Quality issues in judging portfolios: implications for organizing teaching portfolio assessment procedures. Studies in Higher Education.

Wolf K., Dietz M. (1998). Teaching portfolios; Purposes and Possibilities. Teacher Education Quarterly, 25(1), 9-22.

Zeichner K., Wray S. (2001). The teaching portfolio in US teacher education programs: what we know and what we need to know. Teaching and Teacher Education, 17, 613-621. 


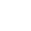




\section{6}

\section{Quality issues in judging portfolios: implications for organizing teaching portfolio assessment procedures ${ }^{5}$}

Abstract. This paper addresses the choice of the most appropriate procedure for the assessment of portfolios used in teacher assessment. A characteristic of modern assessment modes, including portfolios, is that the information they provide is often qualitative and derived from different contexts. Unambiguous, objective rating of portfolios is difficult to achieve, because the richness and uniqueness of the contents of the portfolio necessitate interpretation and taking account of the context before judgement can be passed. From this it follows that the traditional approaches and criteria for evaluating assessment quality are no longer appropriate. We advocate the use of a hermeneutic, interpretative approach to the judging of portfolios as well as the use of quality criteria to establish trustworthiness in performing and monitoring portfolio assessment. A constructivist approach aimed at generating maximum diversity in interpretations and debate on ideas by the different stakeholders is proposed. Finally, we offer recommendations for portfolio assessment procedures for both formative and summative purposes.

Keywords: Teacher assessment, Portfolios, Assessment utilization, Quality criteria

${ }_{5}$ This chapter has been published in Studies in Higher Education as: Tigelaar, E.H., Dolmans, D.H.J.M., Wolfhagen, H.A.P., \& Van der Vleuten, C.P.M. (2005). Quality issues in judging portfolios: implications for organizing teaching portfolio assessment procedures. Studies in Higher Education, 30(5), 595-610. 


\section{Introduction}

In the last two decades, assessment has undergone a major change. This transition from testing to assessment (Gipps, 1994) is characterised by the integration of assessment and instruction, with assessment being viewed as a tool to enhance instruction and learning (Dochy \& McDowell, 1997). In the ideal situation, assessment is no longer primarily focused on measuring the reproduction of knowledge in traditional tests, but it has evolved into a process involving various assessment methods that measure whether construction of meaning has taken place (Dochy, Segers, \& Sluijsmans, 1999). This means that assessments should be meaningful, authentic and challenging to candidates. Moreover, both the learning process and the outcomes of this process must be assessed in a relevant context (Dierick \& Dochy, 2001). This view of assessment places more and more importance on the formative function of assessment. Feedback is a crucial factor in this process. Constructive alignment, i.e. optimal integration of assessment and the learning process, is an important notion in this respect (Biggs, 1996, 1999).

Teacher assessments have been affected by the transition from testing to assessment (Haertel, 1991; Gipps, 1994). Recent insights from teacher research have changed the concepts of teaching and of the way teaching is to be assessed so as to ensure that teacher assessment offers a meaningful learning experience to the teachers who take part in the assessment (Uhlenbeck, Verloop, \& Beijaard, 2002). It is recognised that multiple methods are needed and that information should be gathered over a period of time in order to gain a comprehensive picture of teachers' knowledge and performance (Uhlenbeck et al., 2002). As was stated earlier, for assessment to be a positive learning experience for the teachers involved, it should be authentic, realistic and meaningful to those teachers. Examples of such assessments are procedures involving methods like simulations, peer assessment, co-assessment, selfassessment and portfolios.

A teaching portfolio presents work samples that a teacher has collected over time across various contexts and which are accompanied by reflections (Wolf \& Dietz, 1998). Portfolios can be used for longitudinal assessment of both teaching processes and the teaching products generated by these processes, such as work samples, lesson plans and feedback from students and colleagues, because they provide a rich picture of a teacher's performance. The rich picture of teaching reality provided by a portfolio tends to make this form of assessment highly valid, because it includes longitudinal evidence from multiple sources (Moss, 1994). However, the fact that portfolios contain mostly qualitative information, originating from a variety of contexts, inevitably necessitates interpretation by judges of what the information means as well as consideration of context. This implies that there are serious problems with the reliability of the scores generated by portfolios in terms of consistency, objectivity and comparability 
(Moss, 1994). All this implies that methodologies for evaluating the quality of portfolio assessment, and of the quality of many other new assessment modes as well, can no longer rely on traditional approaches and criteria (Dierick \& Dochy, 2001). Several authors have proposed additional criteria for assuring the quality of new assessment modes (Frederiksen and Collins, 1989; Linn, Baker and Dunbar, 1991; Haertel, 1991). However, more methodological advice and heuristics for evaluating the quality of assessment are needed (Dierick \& Dochy, 2001) and therefore we will have to come up with new ideas for the design and implementation of high-quality new assessment procedures. Another important consideration is that it is questionable to what extent the suggested additional criteria for evaluating the quality of assessment are compatible with current views on teaching and teacher assessment, the assessment of teaching portfolios in particular. In this article, we address methods for judging teaching portfolios and the quality criteria that are appropriate for this purpose and we offer recommendations for ways to organise assessment procedures for teaching portfolios based on the arguments presented.

In our efforts to identify the most appropriate approach to portfolio assessment, we will first elaborate on current views on teaching and teacher assessment, the intended contributions of teaching portfolios and the rich picture of teaching reality that portfolios offer. We argue that a hermeneutic, interpretative approach to portfolio assessment would be the most appropriate approach, given the rich, often qualitative nature of the information in portfolios. In addition, we contend that the criteria for promoting and establishing hermeneutic, interpretative research would be the most appropriate ones for monitoring portfolio assessment processes. Subsequently, we examine which portfolio assessment practices would be suitable for the application of principles of constructivist, hermeneutic approaches to assessment and we use the findings as a basis for recommendations about how procedures might be organised for portfolio assessment for both formative and summative purposes. Finally, we discuss some implications of our recommendations. Note that we use the term 'assessment' with reference to both assessment of candidates and evaluation of assessment programmes.

\section{Identifying the most appropriate approach to judging teaching portfolios}

The traditional definition of validity is the extent to which a test measures what it was designed to measure. From this viewpoint, three types of validity, i.e. content, criterion and construct validity, can be distinguished as intrinsic properties of a test or assessment. Construct validity focuses on the test score as a measure of the psychological characteristic of interest, which should be embedded in a conceptual framework (Gipps, 1994). This means that when a 
test is designed to assess educational leadership, for instance, a clear and detailed definition of the construct of 'educational leadership' must be provided and the test scores must be related to that construct. Content validity refers to the degree to which the content of the test format and the response properties are representative of some defined domain, for example the extent to which the test of educational leadership covers the skills required for a good performance on educational leadership. Criterion validity is a combination of predictive and concurrent validity and refers to the degree to which test scores predict future performance and correlate with the results on other tests measuring the same construct.

Cronbach (1989), Messick (1989) and Kane (1992) use an expanded notion of validity. Instead of regarding validity as a property of the test as such, they relate validity to the meaning of the test scores. According to Cronbach (1989) and Messick (1989; 1995a; 1995b; 1996), it is the meaning or the interpretation of the score that must be valid as well as any implications for action this meaning entails. This concept of validity resulted in Messick's proposal for a unified validity framework, which integrates issues related to content, criterion and construct validity as well as considerations of value implications and social consequences. The recognition that validation goes beyond the properties of a particular test and is related to interpretations, value implications and consequences of the use that is made of a test is of great importance and is widely accepted today. However, despite the importance of this expanded view on validity, we believe that more methodological advice is needed to provide a satisfactory and comprehensive answer to our questions about the use of portfolios for teacher assessment. For this purpose, we want a methodology that is consistent with and applicable to three interrelated essential aspects of teacher assessment using portfolios: (1) current views on teaching and teacher assessment; (2) the intended contributions of portfolios to both teacher development and improvement of the teaching profession, and (3) the rich picture of the teaching reality provided.in portfolios. In the next section, we will elaborate on these three aspects and we will examine the relationships between these aspects and methodological advice offered by various authors. We argue that methodological advice that is appropriate for the use of portfolios in teacher assessment should be consistent with constructivist, hermeneutic approaches to assessment like those used in the methodology of Guba and Lincoln (1989).

\section{Current views on teaching and teacher assessment}

The current view of teaching is that of a complex activity in which thought processes and decision-making processes are equally as important as behaviours and knowledge (Dwyer, 1995). In line with the literature on the broader domain of professional development, teachers are viewed as learners who are actively constructing their own knowledge by interpreting events on 
the basis of existing knowledge, beliefs and dispositions (Eraut, 1994; FeimanNemser \& Remillard, 1996; Putnam \& Borko, 1997). Like other professionals, teachers need a continuing capacity to learn from their experiences (Eraut, 1994). Teachers' professional development and learning can be viewed as unique dynamic processes that continue throughout a teacher's career and in which collaboration and dialogue with colleagues play a vital part (CochranSmith \& Lytle, 1999). It is also generally accepted that teaching is highly contextual and that there are multiple ways of good teaching (Delandshere \& Petrosky, 1998; Uhlenbeck et al., 2002). This means that there can be no clear consensus as to what constitutes good teaching, which implies that good teaching can never be fully defined and that there are no absolute criteria that can be used to evaluate teaching. Nevertheless, it is acknowledged in the field of teacher evaluation that teacher assessments should be based on a conceptual framework that provides some sort of definition of what teachers should know and be able to do. This conceptual framework should cover both theoretical and practical knowledge about teaching (Dwyer, 1995, Uhlenbeck et al., 2002) and reflect the opinions of different stakeholders. The framework should also incorporate a range of acceptable ways of teaching, while steering clear of becoming prescriptive.

In this respect, many authors, for example Messick (1989) and Gielen, Dochy \& Dierick (2003), strongly emphasise the importance of a well-defined conceptual framework as a basis for the description of the construct to be assessed. Assessment tasks and scoring criteria should be relevant to and representative of the construct concerned. This is reflected in quality criteria like content quality, content coverage (Linn et al., 1991) and representativeness (Frederiksen \& Collins, 1989). So far, this view seems compatible with current views on teaching and teacher assessment. Problems emerge, however, when we take a closer look at how this construct is viewed, as reflected in the methodological advice for arriving at a definition of the construct. Perspectives may range from a realist perspective, in which the concepts in the assessment framework are assumed to reflect reality, to constructivist perspectives, in which multiple perspectives are considered possible (Moss, 1992). In constructivist approaches, concepts are viewed as representations in the mind which should be instrumental and meaningful to their users. The methodological advice given from a realist perspective is to describe the nature and boundaries of the domain as well as scientific enquiry undertaken into the nature and boundaries of the domain processes and the ways in which they combine to produce effects or outcomes and thus enable the deduction of testable hypotheses (Messick, 1995a; 1995b). This is less in line with current views on teaching and teacher assessment than the constructivist view, which allows room for multiple perspectives on what constitutes good teaching and which focuses on the opinions of different stakeholders and an understanding of the cultural context to determine what is to be assessed. As adherents of 
constructivist evaluation, Guba \& Lincoln take account of these constructivist considerations in their methodology. They emphasise the building of trust with candidates and the need to understand and be informed about their culture. Furthermore, they stress continuous observation to identify the most relevant characteristics of a situation. In our view, a constructivist approach appears to provide the best reflection of the current views on teaching and teacher assessment.

\section{The intended contributions of portfolios to both teacher development and improvement of the teaching profession}

Since their introduction in the 1980s, portfolios have been expected to contribute to the development and growth of individual teachers and to the improvement of the teaching profession (Bird, 1990; Zeichner \& Wray, 2001). Teaching portfolios should make teachers think more carefully about their teaching and subject matter (Anderson \& DeMeulle, 1998; Bartell, Kaye \& Morin, 1998; Darling-Hammond \& Snyder, 2000). They are also supposed to influence teachers' classroom practices in various ways. Furthermore, in combination with dialogue and debate about education, teaching and learning, portfolios can help teachers to become more self-confident about their teaching practice and gain a better insight into what is expected of them as professionals (Moss, Schutz \& Collins, 1998; Delandshere \& Arens, 2003).

With reference to the intended contributions of assessment to teaching and learning, educators often speak of the consequential validity of assessments in terms of their potential impact on teaching and learning. Messick (1989) was the first to incorporate these consequential considerations into his definition of validity. Messick's advice in this respect is to focus on evidence and rationales in evaluating the intended and unintended short-term and long-term consequences of score interpretation and use, especially those associated with scoring bias or unfairness in test use (1995b). Any negative impact on individuals or groups should not be attributable to construct underrepresentation or construct-irrelevant variance. In other words, low scores should not be caused by omission from the assessment of an aspect that is relevant to the construct to be assessed and that, if present, would have permitted the tested persons to display their competence. Conversely, low scores should not be caused by something irrelevant in the measurement that interferes with the tested persons' demonstration of competence.

Additional validity criteria, such as fairness, meaningfulness and transparency have been proposed to enhance consequential validity (Linn et al., 1991; Frederiksen \& Collins, 1989). Fairness implies that the consequences of assessment should be the same for everyone and that there should be no bias towards any group. Meaningfulness refers to the fact that assessment tasks should be recognisable and considered valuable by the candidates who are assessed. Transparency implies that it should be clearly communicated to 
candidates what they are expected to do in tackling the problems and tasks included in the assessment. This means that candidates should be informed not only as to which knowledge and skills will be assessed, but also by which criteria and standards of good performance their performance will be judged and what steps they can take to improve their performance.

As a safeguard against unintended consequences of test interpretation, Messick (1995a) proposes to explicitly adopt multiple value perspectives on the construct, its properties and internal relations in order to formulate and empirically appraise rival hypotheses. In addition, he advises to pit the benefits and risks of the proposed test against the pros and cons of alternatives in order to protect against actual and potential unintended consequences of test use. Thus, if educational leadership is to be assessed, different viewpoints on how the construct is built up should be formulated. These viewpoints should be seen as hypotheses that serve as starting points for discussion. In addition, various alternative methods to assess performance in relation to the construct should be considered. According to Messick, once construct validity has been demonstrated, the presence of adverse effects will not render the test invalid. By contrast, Cronbach states that any adverse effects raise doubt as to the validity of the use of a test (Moss, 1992). He advises to investigate how stakeholders think decisions that might be made would affect their interests and to be sensitive to these interests in the decision making process. In our view, Messick and Cronbach stress important considerations with respect to potential and real consequences of assessment. We agree with Shepard (1993) that arguments for and against the intended aims of a test and investigation of what a test does other than what it claims to do are key issues in test development. Furthermore, we acknowledge the importance of quality criteria like fairness, meaningfulness and transparency. However, we feel that it would be worthwhile to consider also criteria that are more compatible with intended consequences with respect to learning effects and empowerment, such as more thorough thinking about teaching and subject matter, increased self-confidence about teaching practice and various effects on teachers' classroom practices (Anderson \& DeMeulle, 1998; Bartell, Kaye \& Morin, 1998; Darling-Hammond \& Snyder, 2000; Moss, Schutz \& Collins, 1998; Delandshere \& Arens, 2003). This type of criterion might be found in the 'authenticity criteria' from the constructivist methodology of Guba \& Lincoln (1989). These criteria reflect considerations that are important for the intended contributions of portfolios, such as making portfolio compilers more knowledgeable about their profession, increasing their understanding of different perspectives on teaching and stimulating and empowering them to take action. In Table 6.1, these criteria are summarised. 
Table 6.1. Authenticity criteria (Guba \& Lincoln, 1989)

\begin{tabular}{ll}
\hline Criterion & Central question \\
\hline Fairness & $\begin{array}{l}\text { To what extent have all competing constructions been assessed, exposed, } \\
\text { and considered? }\end{array}$ \\
Ontological authenticity & $\begin{array}{l}\text { To what extent have individual constructions (including those of the } \\
\text { evaluator) become more informed and sophisticated? }\end{array}$ \\
Educative authenticity & $\begin{array}{l}\text { To what extent have individuals (including the evaluator) become more } \\
\text { understanding (even if not more tolerant) of the constructions of others? }\end{array}$ \\
Catalytic authenticity & $\begin{array}{l}\text { To what extent is action stimulated and facilitated by the assessment? } \\
\text { Tactical authenticity }\end{array}$ \\
& $\begin{array}{l}\text { To what extent are individuals empowered to take the action that the } \\
\text { assessment process implies or proposes? }\end{array}$ \\
\hline
\end{tabular}

\section{The rich picture of the teaching reality that is provided in portfolios}

In line with current views on teaching and teacher assessment and to promote the intended contributions of portfolios, teachers who compose a portfolio are often given considerable freedom to select items for their portfolio, which makes each portfolio a unique, personal document (Delandshere \& Petrosky, 1994; Uhlenbeck et al., 2002). Moreover, the information included in portfolios is often qualitative, non-standardised and derived from different teaching contexts. Unambiguous, objective rating of portfolios is difficult to achieve, as assessors have to interpret the information and take account of the context before they can pronounce judgement (Delandshere \& Petrosky, 1998). In this respect, there are serious problems concerning the reliability of portfolio scores in terms of consistency, objectivity, comparability and generalisability (Moss, 1994; Gipps, 1994; Baume \& Yorke, 2002). Standardisation of portfolio entries, scoring procedures and assessment criteria as well as assessor training in applying these criteria independently would improve consistency, objectivity, comparability and generalisability. However, not only would these measures detract from the intended contributions of portfolios and their consequential validity (Moss, 1994), they would also not settle the issue of reliability (Knight, 2002). Asking assessors to give their reasons for making specific judgements, as was done in a study by Baume, Yorke \& Coffey (2004) may help to refine assessment criteria. However, we argue that there is no universal set of assessment criteria. Given the qualitative information in portfolios and the different contexts from which portfolio content originates, judges have no choice but to interpret what is meant and take account of the context. Consequently, we will have to come up with a methodological approach that enables assessors to interpret meaning in context and that will have a positive effect on the intended assessment consequences.

In this context we refer again to Messick's (1995b) important acknowledgement that multiple perspectives and their value implications play a role. However, instead of perceiving multiple perspectives as rival hypotheses from which the 
final definition of the construct is to be derived, we argue that the multiple perspectives of different stakeholders, including the candidates, are all valuable and should be incorporated into the interpretation process. Clearly, what we need is a methodology that: is consistent with considerations from a constructivist viewpoint, that enables carefully constructed interpretations of test information and enhances the intended assessment consequences.

In this sense, we can borrow from the constructivist, hermeneutic approach to assessment, in which evaluators share a holistic and interpretative approach to understanding human phenomena, seeking to understand the whole in the light of its constituents, and continually testing, challenging and revising interpretations until all the available evidence has been accounted for (Moss et al., 1998). As advocates of a constructivist approach to assessment, Guba \& Lincoln (1989) advanced a methodology that fits this approach. However, it also reflects aspects of Messick and Cronbach's methodologies and considerations of fairness, meaningfulness and transparency. In Guba \& Lincoln's view, trust must be built between assessors and candidates, with assessors being aware of candidates' concerns through extensive involvement in the teaching process, as mentioned in the section about current views on teaching and teacher assessment (prolonged engagement and persistent observation). Hypothesis testing can still make an important contribution as long as it is used as a way to arrive at interpretations and take account of different perspectives. For this purpose, assessors should discuss hypotheses with other stakeholders and hypotheses should be challenged by the presentation of counterexamples (peer debriefing and progressive subjectivity). When interpretations are being developed, they should be tested continuously, challenged and revised until they have accounted for all the available evidence (negative case analysis). Interpretations should also be checked with the candidates involved (member checks). All the above-mentioned measures are prerequisite for what Guba \& Lincoln term 'credibility', i.e. enhancing the match between evaluators' interpretations and those of the stakeholders in the field.

Careful record keeping and documentation of the emerging process are essential to keep track of the interpretation procedure. It is also important that conclusions can be traced back to the original data. This requires internal and external inquiry by means of an 'audit trail' to ensure that the assessment process is conducted responsibly and fairly and to provide candidates with an authority to appeal to. These techniques constitute what Guba \& Lincoln call 'dependability' and 'confirmability', i.e. the extent to which the interpretation process is established, traceable, and documented and the extent to which interpretations and conclusions from the assessment process are supported by the original data.

Finally, 'transferability' should be enhanced instead of generalisability, i.e. others should be able to determine whether assessment interpretations are applicable in their own situations. For instance, institutions who want to 
employ a candidate should be able to establish whether this candidate, who was judged to be suitable for a certain job in one institution, will also be able to function adequately within their organisation. This requires the availability of sufficient context information about the assessment conditions (thick description).

All the measures that promote credibility, dependability, confirmability and transferability are taken to 'establish trustworthiness', i.e. to ensure the quality of the interpretation process (Guba \& Lincoln, 1989). In Table 6.2, the four criteria for establishing trustworthiness are summarised together with methodological advice as proposed by Guba \& Lincoln (1989). We feel that the techniques for establishing trustworthiness can also be applied to portfolio assessment in order to enhance the intended assessment consequences. This means that the building of trust between assessors and the teachers who are assessed and paying attention to the concerns of the latter as well as involving them in the assessment procedures and debates on interpretations will promote deeper thinking about teaching and subject matter and help teachers to become more self-confident about teaching practice, which will influence their classroom practices in various ways. In the next section, we will consider how portfolio assessment practices that are consistent with principles of constructivist, hermeneutic approaches may be used in assessment.

\section{Portfolio practices reflecting principles of constructivist, hermeneutic assessment}

In the assessment literature, we have found some recent examples of portfolio practices that reflect principles that are important for constructivist, hermeneutic assessment as defined by Guba \& Lincoln (1989).

Since we see the establishment of trust between evaluator and candidate as an important prerequisite for credibility, we should take measures to ensure that evaluators are aware of the concerns of the candidates (prolonged engagement and persistent observation). A valuable proposal in this respect is the suggestion by Elshout-Mohr \& Oostdam (2001) to select assessors that represent various perspectives on good teaching and are able to explicate the arguments underpinning their judgments. Driessen, Van der Vleuten, Schuwirth, Van Tartwijk \& Vermunt (2005) used this principle in portfolio assessment by assigning all candidates to a supervisor or coach who gives feedback and guidance about their portfolio and performance. 
Table 6.2. Criteria and techniques to establish trustworthiness (Guba \& Lincoln, 1989)

Criterion
Credibility
To what extent do interpretations by
evaluators match those of stakeholders in the
field?

\section{Dependability}

To what extent is the process of making interpretations established, traceable, and documentable?

Confirmability

To what extent can the interpretations and conclusions from the assessment process be confirmed by the original data?

Transferability

To what extent can others apply the assessment interpretations to their own situations?

\section{Techniques}

Prolonged engagement:

Substantial involvement at inquiry site to build trust, understand culture, be informed

\section{Persistent observation:}

To identify the most relevant characteristics in the situation

Peer debriefing:

Engaging in discussion about findings and conclusions with a disinterested peer

Negative case analysis:

Revising working hypothesis until they account for all evidence

Progressive subjectivity:

A peer challenges the evaluator about his or her preconceptions and expectations

Member checking:

Checking interpretations and conclusions with candidates involved; provide the opportunity for correction and adding of information

Audit trail:

Internal and external inquiry of the assessment process

\section{Audit trail:}

Internal and external check whether conclusions can be traced to the original data

Thick description:

Extensive and careful description of time, place and culture

Moss et al. (1998) also encouraged candidates to work with a coach or experienced teacher. Their approach to portfolio assessment also reflects other principles that are important for credibility, such as the need to continuously challenge and test emerging interpretations through debate and counterexamples and the need to use all the available evidence (peer debriefing, negative case analysis, and progressive subjectivity). Moss et al. (1998) asked assessors to consider fourteen guiding questions, which were accompanied by illustrative examples of the performance aspects to be addressed in the assessment. In this approach, assessors first work through a portfolio individually. In the next step, pairs of judges prepare interpretative summaries. While preparing the summaries they look for evidence that is relevant to the guiding questions, they confront their emerging interpretations with counterexamples, they discuss any conflicting interpretations, and revise these until all the evidence has been considered. The final aim is to reach consensus. 
If the judges are unable to reach consensus, this is taken as an indication that the portfolio needs additional attention, because it might raise a set of issues that have escaped attention thus far.

In addition, the need to check interpretations with the candidates involved as another aspect of credibility (member checks) and the need to trace interpretations to their original data as the essence of confirmability could be satisfied by organising tripartite meetings (Webb, Endacott, Grag, Jasper, McMullan \& Scholes, 2003). In tripartite meetings, a candidate, a supervisor and an assessor discuss the interpretations of the candidate's performance that the assessor has derived from the candidate's portfolio. In the discussion, it becomes clearer to both the candidate and the supervisor how the assessor has reached his or her conclusions. The candidate has the opportunity to explain his or her performance and present additional information. Assessors' interpretations could also be discussed with the candidates involved in meetings of candidate and coach, if the coach has a double role, i.e. the coach acts as an assessor for other candidates than the ones he coaches, which implies that the coach is able to explain the assessment procedure to the student (Driessen, et al., 2005). A third technique for checking interpretations was suggested by Elshout-Mohr, Oostdam \& Overmaat (2002). In their approach, assessors and candidates discuss critical situations as a way to clarify performance standards and obtain an understanding of the different perspectives.

Various authors mention an audit trail as a way of ensuring that the assessment process is performed fairly and responsibly, that it is checked against documented records of the interpretations and that candidates can turn to an authority should the need arise. Moss et al. (1998), for example, required assessors to write interpretative summaries, i.e. written documents of the interpretation process. The pairs of judges can serve as internal auditors. Driessen et al. (2005) used interpretation records, a formal assessment plan as well as portfolio and assessment guidelines. They also used external audits in the form of the local examination board and the national organisation for educational auditing and accreditation.

As we stated earlier, transferability can be enhanced by providing information about the assessment context (thick descriptions) in order to enable other institutions to consider the suitability for their particular organisation of a candidate who has passed the assessment. Unfortunately, the literature on portfolio assessment yielded no applications of this principle. We would suggest that evaluators provide a description of the job requirements and the responsibilities involved as well as of the considerations that led to the hiring of a particular candidate for this job as documented in the interpretation record. Candidates could include this information in their portfolio. In this sense, the portfolio as a whole can serve as a 'thick description' to enhance transferability. 


\section{Recommendations}

In this section, we cluster our recommendations concerning the organisation of assessment procedures for teaching portfolios. These recommendations were prompted by considerations that appeared important, in light of the current views on teaching, as a way to further the intended effects of portfolios. The recommendations were derived from criteria and applications that fit with hermeneutic approaches to the interpretation of the rich picture of the teaching reality that is provided in teaching portfolios.

\section{Assessors}

Assessors should be knowledgeable on teaching and should represent multiple perspectives on teaching. Furthermore, they should know the candidates they assess. Portfolios should be read by at least two assessors.

\section{Making interpretations}

Assessors should be enabled to continually challenge and revise their emerging interpretations until they have considered all the available evidence and they should keep record of the interpretation process. This could be achieved by giving assessors guiding questions and aspects of performance to consider, by asking them to provide counterexamples and by encouraging them to engage in debate with each other.

\section{Candidates}

Candidates should be given insight into the process by which assessors arrive at their interpretations and they should be given the chance to supply additional information. Tripartite meetings with an assessor, the candidate and his or her supervisor could be useful in this respect as well as discussions between assessors and candidates about critical situations. Candidates' coaches should be familiar with both the teaching process and the assessment process in order to be able to advise the candidate about his or her performance as well as the choice of items for inclusion in the portfolio.

\section{Internal and external monitoring}

Both the pairs of assessors who read the portfolios and an external audit procedure should determine whether the interpretations and conclusions are supported by the original data and whether they are sound. Assessment guidelines and interpretation records are needed for these checks and to review the results. The local examination board or the national organisation for educational auditing and accreditation could perform the external audit and act as the authority to which candidates can appeal. 


\section{Context descriptions}

Information about the context, time and cultural environment in which an assessment is performed should be available to enable other institutions to assess whether interpretations regarding a particular candidate are applicable to their own situations. Evaluators could provide candidates with information about job requirements and the recorded interpretation of the considerations that led to this candidate's appointment, which can be inserted in the candidate's portfolio. In this way, the portfolio as a whole can serve as a 'thick description' to promote transferability.

\section{Discussion}

A hermeneutic, interpretative approach to the assessment of teaching portfolios appears to be appropriate for teaching as it is currently defined to promote intended assessment contributions and enable the interpretation of the rich, qualitative materials in portfolios. Quality criteria and techniques for establishing trustworthiness appear to be promising methods for judging portfolios and monitoring portfolio assessment processes, given their focus on multiple perspectives, stakeholders' involvement, techniques to interpret meaning in context through debate and dialogue and measures to ensure that these processes are conducted in a fair and responsible manner.

The implementation of our recommendations would burden portfolio readers with a difficult and time-consuming task. They have to read portfolios carefully, challenge, revise and debate their interpretations, consider all the evidence and record how they arrive at interpretations and conclusions. Although we can alleviate the assessors' burden by providing guidelines to help them make interpretations and keep records, the introduction of a systematic procedure and of guidelines for interpretation raises a concern: it might entice readers to lean too heavily on these enabling conditions, which as a result may come to constitute a barrier to in-depth consideration of all the available evidence, as was experienced by Moss et al. (1998). Proper attention should be paid to this issue when preparing readers for their tasks by encouraging them to consider all the evidence carefully and challenge their own interpretations. Moreover, a systematic assessment procedure with well-defined steps and assessment criteria might eventually hamper the ongoing dialogue about what constitutes good teaching. This would be counterproductive, seeing that such a dialogue is of vital importance from the perspective that conceptions of teaching are constantly changing (Moss et al., 1998). This means that the steps to be taken in making interpretations and the assessment framework from which guidelines are derived should be subject to regular re-evaluation.

Although our recommendations have considerable resource implications in terms of time investment, we think that any method for interpreting portfolios 
in a fair and responsible way will inevitably be time-consuming. In addition, we argue that discussions about the interpretation of the evidence provided in a portfolio could be used as professional development activities instead of more traditional and costly staff development programmes, as the assessment process is a valuable learning experience for all those who take part in it. Both assessors and candidates should be involved in this critical reflection on teaching practice and in a professional dialogue to promote the positive effects of assessment, such as insight into the teaching profession, deeper thinking about what constitutes good teaching, improved self-confidence as a teacher, and encouragement to take action in the daily practice of teaching.

We believe that the outcome of the assessment process we propose would be a rich account of the capabilities of the teacher in context, which would be of great value to both employer and candidate. We argue that with pass-fail judgements it is of vital importance that such judgements should be based on a careful, fair and responsible process of interpretation, which should be monitored using the quality criteria from Guba \& Lincoln (1989). However, pass-fail judgements should not solely consist of a grade or a mark, but should be accompanied by a 'thick' description providing sufficient information about a candidate's capacities to enable an informed judgement about his or her suitability for jobs or functions in similar contexts.

We feel that in portfolio assessment, the use of techniques for establishing trustworthiness would enhance the positive effects of this type of assessment, which is in line with the aims that inspired the transition from testing to assessment. The authenticity criteria proposed by Guba \& Lincoln (1989), which are presented in Table 6.1, can be worthwhile in evaluating these effects. Furthermore, when portfolio assessment procedures are organised in accordance with the principles developed by Guba \& Lincoln (1989), both formative and summative assessment will be characterised by listening, dialogue and exchange of views with a minimal imbalance of power. This will benefit the integration of formative and summative assessment functions, another goal aspired at by the change from testing to assessment.

\section{References}

Anderson, R. \& DeMeulle, L. (1998). Porfolio use in twenty-four teacher education programs. Teacher Education Quarterly, 25(1), 23-32.

Bartell, C. Kaye, C. \& Morin J.A. (1998). Teaching portfolios in teacher education. Teacher Education Quarterly, 25(1), 5-8.

Baume, D., \& Yorke, M. (2002). The reliability of assessment on a course to develop and accredit teachers in higher education. Studies in Higher Education, 27(1), 7-25. 
Baume, D., Yorke, M. \& Coffey, M. (2004). What is happening when we assess, and how can we use our understanding of this to improve assessment? Assessment \& Evaluation in Higher Education, 29 (4), 451-477.

Biggs, J. (1996). Enhancing teaching through constructive alignment. Higher Education, 32, 347-364. Biggs, J. (1999). Teaching for quality learning at University. Buckingham: SRHE Open University Press. Bird, T. (1990). The schoolteacher's portfolio: an essay on possibilities. In J. Millman \& L. E. DarlingHammond (Eds.), The new handbook of teacher evaluation. Assessing elementary and secondary schoolteachers (pp. 241-256). Newbury Park: CA: Corwin Press Inc.

Cochran-Smith, M., \& Lytle, S. L. (1999). Relationships of knowledge and practice: Teacher learning in communities. In A. Iran-Nejad \& C. D. E. Pearson (Eds.), Review of research in education (Vol. 24, pp. 249-305). Washington D.C.: American Educational Research Association.

Cronbach, L.J. (1989). Construct validation after thirty years. In R.J. Linn (Eds.), Intelligence: Measurement, theory and public policy. (Proceedings of a symposium in honor of Lloyd G. Humphreys, pp. 147-171). Urbana: University of Illinois Press.

Darling-Hammond, L., \& Snyder, J. (2000). Authentic assessment of teaching in context. Teaching and Teacher Education, 16, 523-545.

Delandshere, G., \& Petrosky, A. R. (1994). Capturing teachers' knowledge: Performance assessment and post-structuralism. Educational Researcher, 23(5), 11-18.

Delandshere, G., \& Petrosky, A. R. (1998). Assessment of Complex Performances: Limitations of Key Measurement Assumptions. Educational Researcher, 27(2), 14-24.

Delandshere,G. \& Arens, S.A. (2003). Examining the quality of evidence in preservice teacher portfolios. Journal of Teacher Education, 54(1), 57-73.

Dierick, S., \& Dochy, F. (2001). New lines in edumetrics: new forms of assessment lead to new assessment criteria. Studies in Educational Evaluation, 27, 307-329.

Dochy, F., Segers, M., \& Sluijsmans, D. (1999). The use of Self-, Peer and Co-assessment in Higher Education: a review. Studies in Higher Education, 24(3), 331-350.

Dochy, F. J. R. C., \& McDowell, L. (1997). Assessment as a tool for learning. Studies in Educational Evaluation, 67(23), 279-298.

Driessen, Van der Vleuten, Schuwirth, Van Tartwijk \& Vermunt (2005). The use of qualitative research criteria for portfolio assessment as an alternative to reliability evaluation: a case study. Medical Education, 39(2), 214-220.

Dwyer, C. A. (1995). Criteria for performance-based teacher assessments: validity, standards, and issues. In A. J. Shinkfield \& D. E. Stufflebeam (Eds.), Teacher evaluation: Guide to effective practice (pp. 62-80). Boston: Kluwer Academic Publishers.

Elshout-Mohr, M. \& Oostdam, R. (2001). Assessment van competenties in een dynamisch curriculum. [Assessment of competencies in a dynamic curriculum]. Amsterdam: SCO Kohnstamm Institute.

Elshout-Mohr, M., Oostdam, R., \& Overmaat, M. (2002). Student assessment within the context of constructivist educational settings. Studies in Educational Evaluation, 28, 369-390.

Eraut, M. (1994). Developing Professional Knowledge and Competence. London, Falmer Press.

Feiman-Nemser, S., \& Remillard, J. (1996). Perspectives on learning to teach. In F. B. Murray (Ed.), The teacher educator's handbook: Building a knowledge base for the preparation of teachers (pp. 6391). San Fransisco: Jossey Bass. 
Frederiksen, J. R., \& Collins, A. (1989). A systems approach to educational testing. Educational Researcher, 18(9), 27-32.

Gielen, S., Dochy, F., \& Dierick, S. (2003). Evaluating the consequential validity of new modes of assessment: the influence of assessment on learning, including pre-, post-, and true assessment effects. In M. Segers \& F. Dochy \& E. Cascallar (Eds.), Optimising new modes of assessment: in search of qualities and standards (pp. 37-54). Dordrecht: Kluwer Academic Publishers.

Gipps, C. V. (1994). Beyond testing: Towords a theory of educational assessment. London, Washington D.C.: Falmer Press.

Guba, E. G. \& Lincoln, Y. S. (1989). Fourth generation evaluation. London Sage.

Haertel, E. H. (1991). New forms of teacher assessment. In G. E. Grant (Ed.), Review of research in education (Vol. 17, pp. 3-29). Washington D.V.: American Research Association.

Kane, M. T. (1992). Quantitative methods in psychology. An argument-based approach to validity. Psychological bulletin, 112(3), 527-535.

Knight, P. T. (2002). Summative assessment in higher education: practices in disarry. Studies in Higher Education, 27(3), 275-286.

Linn, R. L., Baker, E., \& Dunbar, S. (1991). Complex, performance-based assessment: Expectations and validation criteria. Educational Researcher, 23(16), 1-21.

Messick, S. (1989). Validity', in Linn, R. (Ed.). Educational Measurement (3rd edn) American Council on Education, Washington, Macmillan.

Messick, S. (1995a). Standards of Validity and the Validity Standards in Performance Assessment. Educational Measurement: Issues and Practice, 14(4), 5-8.

Messick, S. (1995b). Validity of psychological Assessment. Validation of inferences from persons' responses and performances as scinetific inquiry into score meaning. American Psychologist, 50(9), 741-749.

Messick, S. (1996). Validity of performance assessments. In G. W. Phillips (Ed.), Technical issues in large-scale performance assessment (pp. 1-18). Washington DC: Department of education, office of Educational research and Improvement.

Moss, P. M. (1992). Shifting conceptions of validity in Educational Measurement: Implications for Performance Assessment. Review of Educational Research, 62(3), 229-258.

Moss, P. M. (1994). Can there be validity without reliability? Educational Research, 23(2), 5-12.

Moss, P. M., Schutz, A. M., \& Collins, K. M. (1998). An integrative approach to portfolio evaluation for teacher licensure. Journal of Personnel evaluation in education, 12(2), 139-161.

Putnam, R. T., \& Borko, H. (1997). Teacher learning: Implications of new views on cognition. In B. J. Biddle \& T. L. Good \& I. F. Goodson (Eds.), International handbook of teachers and teaching (pp. 1223-1296). Boston: kluwer.

Shepard, L. (1993). Evaluating test Validity. In L. Darling-Hammond (Ed), Review of Research in Education (Vol. 19, pp.405-450). Washington DC: American Educational Research Association.

Uhlenbeck, A. M., Verloop, N., \& Beijaard, D. (2002). Requirements for an Assessment Procedure for Beginning Teachers: Implications form recent theories on teaching and assessment. Teachers College Record, 104(2), 242-272. 
Webb, C., Endacott, R. Grag, M.A., Jasper, M.A., McMullan, M. \& Scholes, J. (2003) Evaluating portfolio assessment systems: what are the appropriate criteria? Nurse Education Today, 23, 600-609.

Wolf, K., \& Dietz, M. (1998). Teaching portfolios; Purposes and Possibilities. Teacher Education Quarterly, 25(1), 9-22.

Zeichner, K., \& Wray, S. (2001). The teaching portfolio in US teacher education programs: what we know and what we need to know. Teaching and Teacher Education, 17, 613-621. 


\section{7 \\ General discussion}

The aim of the research presented in this thesis was to design and develop a high-quality teaching portfolio that was suitable for both formative and summative purposes. The five studies in which we pursued this aim were focused on a teaching portfolio for experienced university teachers, since the quality of teaching has become a crucial concern at universities today (Biggs, 1999; Seldin, 1991). The overall study design can be characterised as DesignBased Research. The study consisted of an iterative process in which the portfolio procedure was designed and developed in three phases: (1) analysis and design of a teaching competency framework and a portfolio prototype; (2) evaluation of the portfolio's usefulness for professional development by exploring teachers' reflections and participants' opinions about the usefulness of the portfolio; and (3) analysis and design of the portfolio assessment procedure by making recommendations for organising portfolio assessments based on a theoretical analysis of quality criteria and methods for portfolio assessment. In this final chapter, we present the main conclusions of the three phases of the research. The results are discussed in relation to the central dilemmas that have to be resolved by those who design and develop teaching portfolios. Attention is also paid to the limitations of the research and suggestions are offered for further research. We end by providing broad guidelines for practice.

\section{Main conclusions}

\section{Phase 1: Analysis and design of a teaching competency framework and a portfolio prototype}

The first analysis and design phase of this research was aimed at: (1) the development of a teaching competency framework as a starting point for the appraisal of the performance of teachers in higher education; and (2) the identification of the theoretical underpinnings of the teaching portfolio and the development of a proposal for a portfolio prototype, based on these theoretical underpinnings that could be used for both formative and summative purposes.

Chapter 2 described the Delphi study that was part of the first analysis and design phase and in which educational experts rated the importance of several 
competencies for experienced teachers in higher education. A confirmatory factor analysis identified five competency domains which were described in terms of the following teacher roles: 'person as a teacher', 'expert on content knowledge', 'facilitator of learning processes', 'organiser', and 'scholar/lifelong learner'. The framework of teaching competencies that was developed in this study and which consists of broadly defined teacher roles appeared to be a useful starting point for teacher appraisal and the setting of learning goals. Chapter 3 described another part of the first analysis and design phase, i.e. the definition of the theoretical underpinnings for the design of a teaching portfolio prototype followed by the actual development of such a prototype based on the theoretical principles. We then asked people who had had extensive experience with portfolios to determine to what extent the theoretical underpinnings were reflected in the prototype and to indicate any modifications they thought were required. There was general consensus that the prototype did reflect our theoretical choices with respect to portfolio purpose, structure, social interaction and assessment. There was also general agreement that the teaching domains or teacher roles provided an appropriate starting point for structuring the portfolio, provided the roles were used as global guidelines and not as detailed checklists. Finally, the importance of social interactions, discussion and feedback in relation to the portfolio process were emphasised.

\section{Phase 2: Evaluation of the portfolio for formative purposes: exploring teachers' reflections and participants' opinions about the portfolio's usefulness}

The evaluation phase of this research explored the portfolio's usefulness for formative purposes. We investigated this on a small scale in order to work out the design in more detail and explore its usefulness. Two aspects of usefulness were researched: (1) teachers' reflections; (2) participants' opinions about the structure of the portfolio and the social interactions that supported the portfolio process. Chapter 4 reports on the first part of the evaluation phase, in which we explored which aspects are subject of the teachers' reflections about professional work that they insert in their teaching portfolios. We provided illustrative examples of how teachers were found to reflect on various aspects of their functioning. Examples of reflections were found for all aspects of teacher functioning, i.e. environment, behaviour, competencies, beliefs, professional identity and mission. The second part of the evaluation phase was addressed in Chapter 5 . This study examined enabling and disabling factors that affected the extent to which the teaching portfolio stimulated teachers' professional development, particularly participants' opinions about portfolio structure and the social interactions in relation to the portfolio. The results showed that teachers thought that portfolio structure and social interactions, personal coaching in particular, were helpful to them in analysing their teaching. 
However, it was also indicated that the assignments and protocols would be more effective if they were less detailed and directive.

\section{Phase 3: Analysis and design of the portfolio assessment procedure}

Finally, in Chapter 6, we continued the analysis and design process by addressing ways of guaranteeing the quality of portfolio assessment procedures, i.e. methods for judging teaching portfolios and appropriate quality criteria. Furthermore, we offered recommendations for ways of organising assessment procedures for teaching portfolios on the basis of the arguments presented. We concluded that the most appropriate approach to portfolio assessment would be a hermeneutic, interpretative approach, because this would do justice to the qualitative nature of the information in portfolios. In addition, we concluded that criteria that are used in hermeneutic, interpretative research (Guba \& Lincoln, 1989) would be the most appropriate ones for monitoring portfolio assessment processes. We recommend that the most effective procedure for a formative and summative portfolio assessment procedure would be a process that is characterised by listening, dialogue and exchange of views with as little imbalance of power as possible.

\section{General conclusions}

With respect to the main problem definition, i.e.: What form should a teaching portfolio take to be appropriate for both formative and summative purposes and how can the quality of such a portfolio be guaranteed, we can draw some general conclusions. A teaching portfolio procedure for formative and summative purposes should have a flexible, broadly defined structure that provides sufficient help to teachers in setting their learning goals and reflecting on their teaching performance. The quality of the portfolio procedure can be guaranteed when the assessment process is conducted according to the principles and criteria for hermeneutic, interpretative research (Guba \& Lincoln, 1989). Social interactions between portfolio makers and their peers and personal coaches in relation to the portfolio process should be scheduled regularly so as to generate feedback on learning goals and teacher functioning. In the course of this formative process, candidates work towards the summative assessment of their portfolio. The portfolio should be discussed by assessors who represent different perspectives on teaching and who know the candidates quite well. During this process, the assessors continually challenge and revise their emerging interpretations and give candidates the opportunity to add information (credibility). This interpretation process is carefully documented (dependability) in order to enable checks (confirmability) and provide information about the assessment situation and the arguments on which the final judgment is based (transferability). 


\section{Discussion of central dilemmas in relation to the design and development of teaching portfolios}

We will discuss three dilemmas that are central to the reported work: (1) Formative versus summative assessment, (2) The coach as support provider versus assessor, and (3) Analytic versus holistic assessment. Note that these dilemmas are closely interrelated despite the fact that they are discussed under different subheadings.

\section{Formative versus summative assessment}

We intended to design and develop a teaching portfolio in which the formative and summative functions were integrated. Such a portfolio can stimulate teachers' learning and professional development (formative function) and provide a basis for decisions about issues such as the possibility of an educational career (summative function). The dilemma is that this may cause undesirable interference of the two types of goals. There may be negative backwash effects on teacher learning processes, for instance when teachers are only willing to present their strong points in relation to the criteria for summative assessment (Biggs, 1996, 1999). When that happens, teachers may become very selective both in choosing items for their portfolios and in writing illustrative comments on their teaching performance. This would seriously weaken the formative function, i.e.: teachers' learning processes and their professional development, because it would mean that areas that need improvement would remain underexposed to feedback and critical reflection. Since it is known that assessment drives learning (Longhurst \& Norton, 1997), assessment processes should be designed to provide meaningful learning experiences and give candidates a fair chance to show their competencies. In our opinion, formative and summative portfolio assessments should be integrated. The studies in this thesis demonstrate that the two aims can be combined in one portfolio procedure as long as the primary focus is on the learning of teachers and their professional development and the assessment process is performed in a careful and trustworthy manner. Being able to work toward a summative decision from the start motivates teachers to work on their portfolio as was shown in Chapter 3. Apparently, it is not realistic to expect that intrinsic motivation is a sufficient incentive for teachers to spend time on their portfolios and on reflecting on their teaching performance. Teachers also need to be convinced that the ultimate goals and profits make their efforts worthwhile. A combined formative and summative portfolio procedure should be characterised by feedback and dialogue about assessment criteria and an exchange of views about good teaching in a climate with as little imbalance of power as possible. Cheating can be prevented by application of the principle of prolonged engagement, i.e. substantial involvement between assessors and candidates. 


\section{The coach as support provider versus assessor}

The role of the coach has become salient in this thesis. The dilemma in this respect concerns the potential role conflict when the coach takes on the double role of guide and judge of the learning process. The question is: should coaches have the primarily formative function of support provider so as to maximise the safe climate of the coaching relationship or should coaches also have the summative function of assessor, because they are the ones who are most familiar with the candidates achievements?

In our opinion, the two roles should not be strictly separated. According to the principle of prolonged engagement (Guba \& Lincoln, 1989) as outlined in Chapter 6, it is important that assessors should carefully consider all the longitudinal information that is available about candidates' teaching performance. This suggests that coaches, who have the most prolonged engagement with the candidates, are the candidates of choice for the role of assessor. This idea is contested by Driessen, Van der Vleuten, Schuwirth, Van Tartwijk \& Vermunt (2005), who stated that coaches should not be the formal assessors of the teachers they coach, because they are too closely involved with them. The dilemma can be resolved by limited involvement of coaches in the assessment of their own 'pupils'. In this approach coaches give feedback to the teachers they have coached before the portfolio is submitted to the assessment committee. The teachers are responsible for presenting their teaching portfolio to the assessment committee. This is in line with constructivist views on learning and assessment, which stress learner participation and control (Birenbaum, 2003; Segers, 2004). The coach of the teacher who is being assessed might provide additional context information as a member of the team of assessors, which is otherwise comprised of other members, who are knowledgeable on teaching from different perspectives.

\section{Analytic versus holistic assessment}

We intended to achieve a balance between analytic and holistic portfolio assessment in order to make it a worthwhile and meaningful learning experience for the teachers to be assessed. This introduces the dilemma that clearly defined analytic assessment criteria are needed to promote transparency and fairness, whereas on the other hand too much reliance on such criteria might turn portfolio assessment into a meaningless exercise of filling in blanks. The question is, can a proper balance be struck between analytic and holistic aspects of portfolio assessment to establish sound and meaningful assessment procedures?

It is our opinion that meaningfulness and learning opportunities should take precedence over transparency and fairness. This means that, despite acknowledging the importance of defining criteria on the basis of a solid knowledge base of good teaching and the opinions of various stakeholders, we 
should also admit that such criteria can never be exhaustively defined. Thus, criteria should be seen as guidelines that stimulate candidates to reflect on their functioning and encourage assessors to clarify their perspectives and express carefully argued judgements. Finally, discussion and dialogue about what constitutes good teaching will invite assessors to integrate different interpretations that emerge during the assessment of a portfolio into a meaningful holistic judgement. This means that assessment criteria should offer cues for consideration, without the need to pronounce judgement on each criterion. The criteria, or steps for making interpretations, should be subject to regular revision.

\section{Limitations to the study}

This section discusses two limitations of the work: the limited attention for summative portfolio assessment and the characteristics of the research and scope of the study.

\section{Limited attention for summative portfolio assessment}

The possibility of combining the formative and summative assessment functions into one portfolio procedure, which was a central issue in this thesis, has not yet been fully resolved. We explored this dilemma from a theoretical perspective and provided arguments in favour of portfolio judgment processes based on the principles of trustworthiness, which resulted in practical recommendations for the organisation of portfolio assessment procedures. Before we can shed more light on the controversial issue of combining formative and summative purposes, we will have to implement, test and evaluate the recommendations for portfolio assessment procedures that we proposed in Chapter 6. Therefore, we should continue the process of implementing and testing the portfolio by evaluating the combined formative and summative process.

\section{Characteristics of the research and scope of the study}

In Chapter 1, we characterised the research as Design-Based Research with features of both communication and prototyping approaches. However, the research resembles prototyping approaches to Design-Based Research to a limited extent only. The prototyping approach presupposes that several prototypes are being tested. Although we tested our prototype against the opinions of portfolio experts and participants, the number of tests was limited (only two) and the portfolio was put to the test of real practice only once. Another limitation is the scope of the study. The evaluation phase, in which the formative function of the portfolio was investigated, was carried out on a small scale. Further research will have to examine the effects of the portfolio in larger 
groups. Another scope issue concerns the exclusive focus on teachers in higher education, medical doctors in particular, although our aim is to design a portfolio for broader educational contexts. It would be very interesting to investigate whether this portfolio design also works among other teachers and in other educational contexts, such as primary and secondary education.

\section{Suggestions for further research}

We see two directions for future research: further development of the portfolio assessment procedure and the longitudinal impact of portfolio processes on teacher learning and teacher development.

\section{Further development of the portfolio assessment procedure}

In the future, the cyclic process of adapting and testing the portfolio should be continued. The recommendations from Chapter 6 should be developed and tested in practice. According to the principles for establishing trustworthiness, these guidelines should be updated and tested in practice by teachers and by assessors who represent different perspectives on teaching, for instance by discussing sample portfolios. The focus should be on the development of guidelines for interpretation and discussion. It is likely that assessors' interpretations will be coloured by their own teaching experiences and information from the context (Van der Schaaf, Stokking \& Verloop, 2005). Thus, in-depth investigation is needed to understand the interpretation processes of assessors using these guidelines and the influence of context and personal teaching experiences on these processes. Another important subject of inquiry is the internal and external monitoring and quality assurance of portfolio assessment processes, which should employ criteria for establishing trustworthiness instead of psychometric criteria.

\section{Longer term impact of portfolio processes on teacher learning and teacher development}

Future research should focus on the collection of longitudinal data about portfolio processes and the effects on teachers' professional development. The focus should be on teachers' reflective processes, whether their insight into different viewpoints improves, the increase in their insight into what is expected from them as professionals and whether suggestions for improvement do indeed lead to improvements in teaching practice and teacher empowerment. With respect to teachers' reflective processes, more research is needed into how reflection can best be defined and measured and how reflective skills can be fostered. In addition, given that reflection should not be a goal in itself, it would be worthwhile to investigate how reflective abilities are related to teaching competence and in which teaching situations reflective skills 
are particularly important. Such research was also advocated by MansvelderLongayroux, Beijaard \& Verloop (2002). In addition, research should also target the relationship between the person as a teacher and inner aspects of teacher functioning (Korthagen, 2004) and teaching competencies and performance. Self-study research might be useful in this respect (Loughran, 2004).

\section{Practical implications}

Although more detailed guidelines were given in the previous chapters, we want to present some broadly defined practical implications that might be of use to portfolio designers and faculty developers. These guidelines arise from the main issues in the use of portfolios, i.e. purpose, structure, social interaction, and assessment.

Formative goals should be at the heart of the portfolio process, but the summative goal should be kept in view from the start

We would recommend the integration of formative and summative purposes of assessment by focusing on formative goals while working towards the summative final goal. This means that learning opportunities and teachers' professional development should be at the heart of portfolio assessment, but the ultimate summative purpose, i.e. a decision about the possibility of a career in teaching, should be communicated to the candidates at the earliest opportunity and candidates should know what is expected from them in this respect. It is important, however, that these expectations should be broadly defined and be subject to discussion among different stakeholders during the portfolio process. This recommendation is grounded in the principle that assessment drives learning (Longhurst \& Norton, 1997). Moreover, this thesis provided indications that working toward a summative goal motivates teachers involved in portfolio processes.

\section{Provide flexibility within structure}

With respect to portfolio structure, we recommend the combination of a broadly defined structure and flexibility, which opens the possibility to tailor a portfolio to teachers' individual wishes. Structure should be fine-tuned with the participants in the context in which they are working. This is in line with constructivist views on learning that emphasise learner participation and control (Birenbaum, 2003). Empirical results in this thesis also indicate that a flexible structure is important for promoting the effectiveness of teaching portfolios as an instrument for fostering professional growth. 
Provide many opportunities for social interaction and allow teachers to choose their own coaches

We think that it is crucial to offer many opportunities for social interaction as part of the portfolio process. Social interaction can deepen reflective processes and provide teachers with feedback and ideas for improvement. The literature indicates that successful portfolio learning is predicated on effective social interactions (Darling, 2001). The study described in Chapter 5 showed that social interaction strengthened the effects of individual learning processes. The results of this study indicate that when teachers can select their own coaches, the chance of a supportive and satisfying coaching relationship is heightened, provided coaches are qualified for their task by teaching experience and coaching skills. Coaches should not be direct colleagues of the teacher in question, however, because coaching relationships must be safe and confidential (Ackland, 1991; Freidus, 1998). Because successful coaching is predicated on continued orientation, instruction and follow-up, it is important that coaching, i.e. conversations with peers and personal coaches, should be an ongoing process, with regular meetings.

Perform careful and trustworthy portfolio interpretation processes, taking broadly defined assessment frameworks that reflect the opinions of different stakeholders as a point of departure

With respect to portfolio assessment, we recommend a careful assessment process that is characterised by listening, dialogue, exchange of views and as little imbalance of power as is feasible. This recommendation is grounded in the analysis in Chapter 6, in which we concluded that hermeneutic interpretation processes according to the principles of trustworthiness (Guba \& Lincoln, 1989) are most in line with current views on teaching, the richness of portfolios, and the interpretation processes that assessors engage in when judging portfolios. Furthermore, in agreement with the literature on teaching, we recommend the use of assessment frameworks that are broadly defined and reflect the opinions of various stakeholders, including those of the participating teachers (Dweyer, 1995; Uhlenbeck, Verloop \& Beijaard, 2002).

\section{Final remark: implementation}

Before the implementation of a teaching portfolio design in a university or other educational institution, it is important to establish the feasibility of the portfolio and its aims for the context of that particular organisation. The portfolio purposes, including formative and summative orientations and coaching goals, should be in accordance with the culture and objectives of the organisation. This also implies that the organisation should be ready to use portfolios. Prerequisites for this are that the organisation acknowledges the value of 
teaching and teachers' professional development. The organisation can show that it recognises the need to stimulate and reward good teaching and foster teachers' professional growth by scheduling dedicated time for teachers to work on their portfolio, engage in critical reflection with peers and coaches and experiment with suggestions for improving their teaching. Furthermore, discussions about what constitutes good teaching should be stimulated. Such discussions can be conducted on the basis of portfolios compiled by excellent teachers and during appraisal interviews with teachers. In addition, the organisation should approve the portfolio assessment procedure and provide opportunities for teaching careers. Finally, providing personnel with the opportunity to go through an assessment process that is organised according to the principles of trustworthiness (Guba \& Lincoln, 1989) will benefit the development of staff and their commitment to teaching, which is likely to enhance the quality of teaching practice in higher education.

\section{References}

Ackland, R. (1991). A review of the peer coaching literature. Journal of Staff Development, 12, 22-27. Biggs, J. (1996). Enhancing teaching through constructive alignment. Higher Education, 32, 347-364. Biggs, J. (1999). Teaching for quality learning at university. Buckingham: SRHE Open University Press. Birenbaum, M. (2003). New insights into learning and teaching and their implications for assessment. In M. Segers, F. Dochy \& E. Cascallar (Eds.), Optimising new modes of assessment: In search of qualities and standards (pp. 13-36). Dordrecht/Boston/London.

Darling, F. L. (2001). Portfolio as practice: The narratives of emerging teachers. Teaching and Teacher Education, 17, 107-121.

Driessen, E. W., Van der Vleuten, C. P. M., Schuwirth, L. W. T., Van Tartwijk, J., \& Vermunt, J. (2005). The use of qualitative research criteria for portfolio assessment as an alternative to reliability evaluation: A case study. Medical Education, 39(2), 214-220.

Dweyer, C. A. (1995). Criteria for performance-based teacher assessments: Validity, standards, and issues. In A. J. Shinkfield \& D. E. Stufflebeam (Eds.), Teacher evaluation: Guide to effective practice (pp. 62-80). Boston: Kluwer Academic Publishers.

Freidus, H. (1998). Mentoring portfolio development. In N. Lyons (Ed.), With portfolio in hand: Validating the new teacher professionalism (pp. 51-68). New York, London: Teachers College Press.

Guba, E. G., \& Lincoln, Y. S. (1989). Fouth generation evaluation. London Sage.

Korthagen, F. A. J. (2004). In search of the essence of a good teacher: Towards a more holistic approach in teacher education. Teaching and Teacher Education, 20, 77-97.

Lonckhorst, N., \& Norton, L.S. (1997). Self-assessment in coursework essays. Studies in Educational Evaluation, 23, 319-330.

Loughran, J.J. (2004). Learning through self-study: The influence of purpose, participants and context. In: J.J. Loughran, M.L. Hamilton, V.K. Laboskey \& T. Russell (Eds.), International 
Handbook of Self-Study of Teaching and Teacher Education Practice (pp. 151-192). Dordrecht: Kluwer.

Mansvelder-Longayroux, D., Beijaard, D., \& Verloop, N. (2002). Het portfolio als reflectieinstrument voor docenten-in-opleiding. [The portfolio as an instrument for reflection by teachers in training] Pedagogische Studiën, 79(4), 269-286.

Segers, M. (2004). Assessment en leren als een twee-eenheid: Onderzoek naar de impact van assessment op leren. [The dyad of assessment and learning: a study of the impact of assessment on learning]. Inaugural address given at the acceptance of professorship in Pedagogics, Educational Sciences in particular, at Leiden University. Leiden: Leiden University.

Seldin, P. (1991). The teaching portfolio: A practical guide to improved performance and promotion/tenure decisions. Bolton: MA: Anker.

Uhlenbeck, A. M., Verloop, N., \& Beijaard, D. (2002). Requirements for an assessment procedure for beginning teachers: Implications from recent theories on teaching and assessment. Teachers College Record, 104(2), 242-272.

Van der Schaaf, M., Stokking, K. \& Verloop, N. (2005). De invloed van cognitieve representaties van beoordelaars op hun beoordeling van docentportfolio's. [The influence of assessors' cognitive representations in their assessments of teaching portfolios]. Pedagogische Studiën, $82(1), 7-26$. 


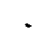




\section{Summary}

\section{Introduction and problem definition}

The research that is reported in this thesis is concerned with the design and development of a teaching portfolio that can be used for both formative and summative purposes. The research was based on recent views on learning and assessment. Constructivist theories of learning emphasise active knowledge construction, reflection, learning in practice, participation and active control of learning by students (Atkins, 1995; Birenbaum, 2003; Tynjälä, 1999). These theories have resulted in a shift from testing to assessment (Gipps, 1994). Instead of passing judgment in terms of pass or fail scores, fostering the learning of students has become the new primary purpose of assessment (Dochy \& McDowell, 1997). Assessment should be meaningful, authentic and challenging (Dochy, Segers, \& Sluijsmans, 1999). Learning processes and their outcomes should be judged within relevant contexts. Instead of relying on a single test, assessment should be based on information that has been collected over a prolonged period of time and from a variety of sources (Uhlenbeck, Verloop, \& Beijaard, 2002). The core issue in assessment is the interconnectedness of assessment and the learning process, i.e. alignment (Biggs, 1996, 1999). A good example of an instrument that meets these requirements for assessment is the portfolio.

Portfolios have come to be increasingly used in the assessment of teacher performance (Zeichner \& Wray, 2001). A teaching portfolio consists of evidential material that has been collected by a teacher over a prolonged period of time in different contexts. The evidence is commented on and clarified by reflections of the portfolio author about his or her functioning (Wolf \& Dietz, 1998). Portfolios are derived from the world of art and architecture, where artists and architects collect samples of their work in folders which they use to show potential customers evidence of their talent, development, and achievement. Teaching portfolios may contain artefacts, such as videotapes showing the teacher working with a group of students, transparencies used to support lectures, et cetera. In actual fact, a teaching portfolio is a dressed CV: it displays a rich array of evidence of a teacher's professional development. Portfolios can be used formatively, i.e. as an instrument to help teachers reflect on their functioning and to enhance their professional development, and they can be used summatively, i.e. as a basis for decisions about promotion or certification (Anderson \& DeMeulle, 1998; Bartell, Kaye, \& Morin, 1998; Snyder, Lippincott, \& Bower, 1998). Although it is often said that portfolios are eminently suited to integrate formative and summative assessment, these two 
functions are generally kept separate. This is attributable to a fear of 'backwash effects' (Biggs, 1996; 1999) when these functions are combined, i.e. adverse interactions of formative and summative purposes. For instance, summative goals might tempt teachers to act strategically and include in the portfolio artefacts that are illustrative of their strengths only. This might detract from teachers' learning processes and reflective processes as well as the portfolio's validity. The possibility of integrating formative and summative functions in one portfolio procedure remains a controversial issue (Edgerton, Hutchings, \& Quinlan, 1991; Seldin, 1991; Wolf \& Dietz, 1998). Another issue that is often viewed as problematic is the quality of portfolio assessment procedures, in particular the reliability of portfolio assessment. This point is most often raised when portfolios are used for high stakes summative assessment (Davies \& LeMahieu, 2003; Wilkerson \& Lang, 2003). The preceding considerations have resulted in the problem definition that was addressed in this thesis: What form should a teaching portfolio take to be appropriate for both formative and summative purposes and how can the quality of such a portfolio be guaranteed?

In addition to the theoretical relevance of this thesis, the outcomes of the research may be helpful for designers of assessment methods by offering them heuristics and methodological advice for the development of high-quality assessment, such as portfolio procedures. Increased insight into how learning and assessment can be integrated to foster teachers' professional development may be useful to those who are working in the field of teacher professionalisation and staff development.

The focal point of the research is the design and development of a teaching portfolio for experienced university teachers. The procedure was designed and tested among a small group of experienced medical school teachers.

The research design can be characterised as Design Based Research (Barab \& Squire (Eds.), 2004; Sandoval, W. \& Bell, P. (Eds.)., 2004), also known as developmental research (Van den Akker, 1999). This type of research design is comprised of a cyclic process of analysis, design, evaluation and revision. Three phases can be discerned in the research reported in this thesis:

(1) Analysis and design of a teaching competency framework and a portfolio prototype;

(2) Evaluation of the portfolio's usefulness for formative purposes;

(3) Analysis and design of the procedure for portfolio assessment.

Phase 1: Analysis and design of a teaching competency framework and a portfolio prototype;

The first analysis and design phase involved the development of a framework of teacher competencies and a prototype portfolio. Chapter 2 reports on a Delphi study in which experts in the field of education rated the items on a list of teacher competencies according to their relevance for teachers in higher 
education. The ratings remained stable after two rounds and consensus was reached for $59 \%$ of the items. Confirmatory factor analysis was performed for the three highest rated items of each domain. This resulted in five competence domains: 'Person as a teacher', 'Expert on content knowledge', 'Facilitator of learning processes', 'Organiser' and 'Scholar / lifelong learner'. The resulting competency framework consists of broadly defined competencies that offer excellent starting points for teacher appraisal and the setting of learning objectives.

Chapter 3 describes the development of a portfolio prototype that can be used formatively as well as summatively. We first defined the theoretical underpinnings of the portfolio's aim, structure, social interaction and assessment on the basis of work by Zeichner \& Wray (2001) and other portfolio literature. This provided the theoretical foundation for the portfolio prototype. The prototype design was then submitted to experts in the field of portfolio assessment and their opinions were sought in an interview study. They were asked to give their views as to how well the theoretical underpinnings were reflected in the prototype and which modifications they thought were needed. There was general consensus among the experts that the theoretical principles were clearly visible in the design. Some points were raised and recommendations made about the portfolio's goal, structure, social interaction and assessment. As for the portfolio's purpose, doubts were raised about the feasibility of combining formative and summative goals in one portfolio. As for the structure, the interviewees pointed out that guiding questions and suggestions for evidential materials might inhibit teachers' creativity and learning processes. We incorporated into the prototype the experts' advice to include only domains and not guiding questions. Another suggestion from the experts was to include peer feedback in the social interaction that was a component of the portfolio process. The experts objected to the idea of having coaches make recommendations to the portfolio assessment committee with regard to their 'pupils', because of potential negative impact on the safety of the coaching relationship. The experts' suggestions were incorporated into the design of the prototype. It was said that predetermined assessment criteria might have a negative effect: they might encourage teachers to be highly selective in deciding which evidential materials to include in their portfolio. As a result, the potential of the portfolio to present a rich, valid picture of teachers' achievements would suffer. There was general agreement that feedback is a crucial factor in ensuring that portfolio assessment offers teachers a valuable educational experience. The details of the assessment procedure remained to be finalised.

\section{Phase 2: Evaluation of the portfolio's usefulness for formative purposes}

The second phase of the research comprised an evaluation of the portfolio's usefulness for formative purposes. We examined two aspects of usefulness: (1) teachers' reflections; (2): participants' opinions about the portfolio's structure 
and related social interactions. The portfolio was tested in a small scale study. Five experienced teachers and their five coaches participated in the study. The participating teachers first undertook a set of assignments intended to stimulate reflection, i.e. in-depth thought about their functioning as teachers. The teachers drew up a Timeline of their teaching career, described a Critical incident, set Learning goals for themselves, selected Evidential materials, drew up a Competency profile, and created a Portfolio containing all the assignments. Each assignment was followed by a peer feedback meeting or a meeting with teachers' personal coaches.

In Chapter 4, we explored which aspects of professional functioning were object of teachers reflections within the context of the portfolio process. We presented illustrative samples of teachers' reflections about different aspects of their functioning. The analysis yielded examples of reflections on all aspects of functioning (Korthagen, 2004): the environment, behaviour, competencies, convictions, professional identity and mission. Examples of reflection on competencies were easier to detect than those of reflections on convictions, professional identity and mission, however. The use of different teacher roles in structuring the portfolio may have focused teachers' attention primarily on competencies. The analyses of the portfolio excerpts may be useful for teacher trainers and coaches in conducting portfolio conversations with teachers about their professional development.

Chapter 5 examined participants' perceptions in respect of the results and the enabling and disabling factors of the portfolio's structure and social interaction in relation to professional development. The structure of the portfolio consisted of teacher roles, assignments and conversation protocols, which were intended to offer guidance to teachers in structuring portfolio content without obstructing their individual learning processes. Social interaction took the form of peer feedback sessions and conversations of individual teachers with their coaches The objective of the social interactions was to reinforce the effects of the assignments. During the peer sessions, the teachers shared experiences and reflected on issues they encountered in their professional practice. During the coaching conversations, the coach asked probing questions about the teacher's work and plans to achieve his or her personal learning objectives. The teachers selected their own coaches, who had to meet the criteria of being familiar with the medical school organisation and ample educational experience. Obviously, the coaches' qualities included good interviewing skills, i.e. listening and asking questions. Because it was important that the teachers should be able to show their vulnerabilities in the conversations with their coach, direct superiors or colleagues of the teachers were excluded from this role. The conversations with the coach were structured along the lines of global conversation protocols. The five participating teachers and their coaches were individually interviewed about their experiences with the portfolio. The participants perceived the structure and social interactions on 
the whole as helpful tools for analysing teachers' functioning. The coaching conversations were deemed particularly useful. The assignments and the conversation protocols were perceived as too directive and detailed, however. The positive appreciation of the coaching conversations may be associated with the fact that the teachers had been allowed to select their own coaches. This study resulted in a number of practical guidelines for establishing a wellbalanced portfolio structure and related social interactions.

\section{Phase 3: Analysis and design of the portfolio assessment procedure}

The analysis and design phase of the research was continued in the study described in Chapter 6. In this study, the development of the assessment procedure was continued. The goal was to establish a procedure and define appropriate quality criteria for summative portfolio assessment in line with current views on teaching and teacher assessment, the expected contribution of teaching portfolios to teachers' professional development and improvement of the teaching profession and the rich picture of teaching practice that portfolios can provide. On the basis of a theoretical analysis, we argued in favour of a hermeneutic, interpretative approach to portfolio assessment based on the criteria of 'trustworthiness', developed by Guba \& Lincoln (1989): credibility, dependability, confirmability and transferability. Credibility refers to the match between assessors' interpretations and those of different stakeholders in the field. Dependability is concerned with the recording and documenting of the interpretation process to ensure that the steps of the process that led to the final assessment can be retraced afterwards. This is also important with regard to confirmability, i.e. the possibility to confirm the interpretations and conclusions by recourse to the original data. Finally, transferability requires extensive descriptions of the assessment conditions and conclusions to enable others to ascertain whether the assessment results are valid for their particular situation. We made recommendations for the organisation of assessment procedures for teaching portfolios on the basis of an analysis of various portfolio assessment procedures in which principles of constructivist, hermeneutic approaches were applied. These recommendations resulted in an assessment procedure that is characterised by an exchange of views, dialogue and listening to each other in a situation with a minimal imbalance of power. Portfolio procedures that adhere to constructivist, hermeneutic principles and criteria may achieve careful and high-quality assessment procedures, which can be of value and educationally worthwhile to all those involved. Such a procedure may also foster the integration of formative and summative goals.

\section{General discussion}

A general discussion of the research in this thesis is presented in Chapter 7. The discussion is divided into five parts: the main conclusions, a discussion of the central dilemmas that are to be resolved in designing and developing teaching 
portfolios, the limitations of the research, suggestions for further research and implications and recommendations for practice.

First, we discuss the principal conclusions that emerged from the three phases of the research. A teaching portfolio procedure that is suitable for both formative and summative goals must have a flexible structure that gives just the right amount of direction to teachers in setting learning objectives and reflecting on their professional functioning. Social interactions with peers and personal coaches should be scheduled regularly in order to provide teachers with feedback about their learning objectives and functioning. The quality of portfolio procedures can be assured by application of the 'trustworthiness' criteria developed by Guba \& Lincoln (1989). In selecting assessors of portfolios, care should be taken that they have expertise in the educational field concerned and that they know the candidates. Assessors should carefully consider their interpretations and critique, discuss and revise them, using for instance sample questions and hypotheses. The candidates should be involved in the assessment procedure as well and be given the opportunity to provide additional information (Credibility). The consecutive steps of the interpretation process should be well documented in order to enable internal and external checks by audits. Audits may also serve as appeal authority for candidates (Dependability \& Confirmability). Extensive information should be available about the assessment conditions and the arguments underpinning the final assessment (Transferability).

There are three dilemma's that must be resolved by those who design and develop procedures for the assessment of teaching portfolios: formative versus summative assessment; the supportive role of the coach versus the role of assessor; and analytic versus holistic assessment.

The limitations of the research reside in the lack of detail in the design of the summative assessment procedure, the fact that the prototype was tested only twice with one test being performed in a practice-based situation, and the scope of the research. Our recommendations with regard to portfolio assessment procedures need further development and should be subjected to empirical testing. In this way the prototype can be updated and evaluated. It is to be recommended that the prototype should be developed and tested within a larger population and in different contexts.

Suggestions for further research are: further development of the portfolio assessment procedure and the impact that longitudinal portfolio processes may have on teachers' learning and professional development. Attention should also be given to guidelines for the interpretation and discussion of portfolios. Another interesting research theme seems to be the monitoring of the quality of portfolio assessment procedures according to criteria of 'trustworthiness' instead of psychometric criteria. 
The practical implications of this thesis are described for the different dimensions of portfolio usage: purpose, structure, social interactions and assessment.

Chapter 7 ends with a conclusive remark about the implementation of portfolios. Portfolio procedures must be firmly embedded within an organisation's mission and be given a clearly defined position within the organisation's human resource policies. We expect that striving towards assessment according to the principles of hermeneutic, interpretative research will promote staff development and enhance their commitment to teaching. This is expected to be highly beneficial to the quality of education.

\section{References}

Anderson, R., \& DeMeulle, L. (1998). Portfolio use in twenty-four teacher education programs. Teacher Education Quarterly, 25(1), 23-32.

Atkins, M. (1995). What should we be assessing. In P. Knight (Ed.), Assessment for learning in higher education (pp. 25-33). London: Kogan Page.

Barab, S., \& Squire, K. (Eds.). (2004). Design-Based Research: Clarifying the terms [Special issue]. The Journal of the Learning Sciences, 13(1).

Bartell, C., Kaye, C., \& Morin, J. A. (1998). Teaching portfolios in teacher education. Teacher Education Quarterly, 25(1), 5-8.

Biggs, J. (1996). Enhancing teaching through constructive alignment. Higher Education, 32, 347-364.

Biggs, J. (1999). Teaching for quality learning at University. Buckingham: SRHE Open University Press.

Birenbaum, M. (2003). New insights into learning and teaching and their implications for assessment. In M. Segers \& F. Dochy \& E. Cascallar (Eds.), Optimising new modes of assessment: In search of qualities and standards (pp. 13-36). Dordrecht/Boston/London.

Davies, A., \& LeMahieu, P. (2003). Assessment for learning: Reconsidering portfolios and research evidence. In M. Segers \& F. Dochy \& E. E. Cascallar (Eds.), Optimising new modes of assessment: In search of qualities and standards. Dordrecht/Boston/London: Kluwer Academic Publishers.

Dochy, F., Segers, M., \& Sluijsmans, D. (1999). The use of Self-, Peer and Co-assessment in Higher Education: a review. Studies in Higher Education, 24(3), 331-350.

Dochy, F. J. R. C., \& McDowell, L. (1997). Assessment as a tool for learning. Studies in Educational Evaluation, 67(23), 279-298.

Edgerton, R., Hutchings, P., \& Quinlan, K. (1991). The teaching portfolio: capturing the scholarship in teaching. Washington D.C.: AAHE.

Gipps, C. V. (1994). Beyond testing: Towards a theory of educational assessment. London, Washington D.C.: Falmer Press.

Guba, E. G. \& Lincoln, Y. S. (1989). Fourth generation evaluation. London Sage.

Korthagen, F. A. J. (2004). In search of the essence of a good teacher: towards a more holistic approach in teacher education. Teaching and Teacher Education, 20, 77-97. 


\section{Summary}

Sandoval, W. \& Bell, P. (Eds.). (2004). Design-based research methods for studying learning in context [Special Issue]. Educational Psychologist, 39(4).

Seldin, P. (1991). The teaching portfolio: a practical guide to improved performance and promotion/tenure decisions. Bolton: MA: Anker.

Snyder, J., Lippincott, A., \& Bower, D. (1998). The inherent tensions in the multiple use of portfolios in teacher education. Teacher Education Quarterly, 25(1), 45-60.

Tynjälä, P. (1999). Towards experts knowledge? A comparison between a constructivist and a traditional learning environment in the university. International Journal of Educational Research, 31, 357-442.

Uhlenbeck, A. M., Verloop, N., \& Beijaard, D. (2002). Requirements for an Assessment Procedure for Beginning Teachers: Implications from recent theories on teaching and assessment. Teachers College Record, 104(2), 242-272.

Van den Akker, J. (1999). Principles and methods of development research. In J. Van den Akker \& R. B. Branch \& K. L. Gustafson \& N. M. Nieveen \& T. Plomp (Eds.), Design approaches and tools in education and training (pp. 1-14). Dordrecht, The Netherlands: Kluwer.

Wilkerson, J. R., \& Lang, W. S. (2003). Portfolios, the pied piper of teacher certification assessments: legal and psychometric issues. Educational Policy Analysis Archives, 11(45), retrieved [Date] from http://epaa.asu/epaa/v11n45/.

Wolf, K., \& Dietz, M. (1998). Teaching portfolios; Purposes and Possibilities. Teacher Education Quarterly, 25(1), 9-22.

Zeichner, K., \& Wray, S. (2001). The teaching portfolio in US teacher education programs: what we know and what we need to know. Teaching and Teacher Education, 17, 613-621. 


\section{Nederlandse samenvatting}

\section{Inleiding en probleemstelling}

Dit proefschrift doet verslag van het ontwerp en de ontwikkeling van een docentportfolio dat gebruikt kan worden voor zowel formatieve als summatieve doeleinden. Achtergrond van het onderzoek zijn nieuwe visies op leren en toetsen. Constructivistische visies op leren leggen nadruk op actieve kennisconstructie, reflectie, praktijkleren en participatie en zelfsturing door lerenden (Atkins, 1995; Birenbaum, 2003; Tynjälä, 1999). Onder invloed van deze theorieën is er een verschuiving opgetreden van toetsen naar assessment (Gipps, 1994). Assessments moeten niet langer 'afrekenen'; idealiter fungeren ze als middel om leren te bevorderen (Dochy \& McDowell, 1997). Assessments dienen betekenisvol, authentiek en uitdagend te zijn (Dochy, Segers, \& Sluijsmans, 1999). Zowel leerprocessen als de producten van die processen dienen beoordeeld te worden in een relevante context. Ook moet gedurende langere tijd informatie worden verzameld en dienen meerdere bronnen te worden gebruikt (Uhlenbeck, Verloop, \& Beijaard, 2002). Afstemming en integratie van assessment en het leerproces staat hierbij centraal (Biggs, 1996, 1999). Een voorbeeld van assessments zijn portfolio's.

Portfolio's worden de laatste jaren steeds meer gebruikt voor assessment van docenten (Zeichner \& Wray, 2001). Een docentportfolio bestaat uit een verzameling bewijsstukken, verzameld gedurende langere tijd, afkomstig uit verschillende contexten, toegelicht door beschouwingen op het functioneren in onderwijs (Wolf \& Dietz, 1998). Het begrip portfolio komt uit de wereld van kunst en architectuur. Kunstenaars beschikken vaak over een map met voorbeelden van eigen werk die een beeld geven van de ontwikkeling die ze hebben doorgemaakt en die een impressie geven van hun beste prestaties. Docentportfolio's kunnen bijvoorbeeld bevatten: een stukje video over begeleiding van een groep studenten, overheadsheets gebruikt ter ondersteuning van een college, enzovoort. Eigenlijk zijn alle materialen geschikt, op voorwaarde dat de eigenaar toelicht wat het is, waarom het materiaal is gekozen en wat het illustreert. Portfolio's zijn in feite een aangekleed C.V.: ze geven een rijk beeld van een docent en zijn of haar ontwikkeling. Behalve als leerinstrument om docenten te laten nadenken over het eigen functioneren en om hun professionele ontwikkeling te bevorderen (formatief), worden portfolio's ingezet om beslissingen te nemen over bevordering of certificatie (summatief) (Anderson \& DeMeulle, 1998; Bartell, Kaye, \& Morin, 1998; Snyder, Lippincott, \& Bower, 1998). Hoewel vaak wordt gezegd dat portfolio's bij uitstek geschikt zijn om de formatieve en summatieve 
functies van assessment te integreren, worden beide functies toch vaak gescheiden gebruikt. Bij gecombineerd gebruik vreest men 'backwash effects' (Biggs, 1996; 1999): negatief interveniëren van summatieve en formatieve doeleinden. Summatieve doelen zouden docenten bijvoorbeeld kunnen aanzetten om hun portfolio heel strategisch samen te stellen en vooral te focussen op sterke punten. Dit gaat ten koste van leerprocessen en reflectieprocessen van docenten en de validiteit van het portfolio. De mogelijkheid van integratie van beide doelen in één portfolioprocedure is een controversieel discussiepunt (Edgerton, Hutchings, \& Quinlan, 1991; Seldin, 1991; Wolf \& Dietz, 1998). Ook de kwaliteit van portfolio assessment procedures, in het bijzonder de betrouwbaarheid van portfoliobeoordelingen, ziet men vaak als problematisch, vooral bij gebruik van portfolio's bij gewichtige summatieve beslissingen (Davies \& LeMahieu, 2003; Wilkerson \& Lang, 2003). Hieruit vloeit de volgende probleemstelling van dit proefschrift voort: Hoe moet een docentportfolioprocedure eruit zien die bruikbaar is voor zowel formatieve als summatieve doeleinden en hoe kan de kwaliteit van zo'n procedure worden gegarandeerd?

Behalve theoretisch relevant zijn de opbrengsten en uitkomsten van dit onderzoek van belang voor ontwerpers van assessments vanwege hun behoefte aan heuristieken en methodologisch advies ten aanzien van het ontwikkelen van assessments van goede kwaliteit, zoals portfolioprocedures. Meer inzicht in de vraag hoe leren en assessment kan worden geïntegreerd om zo professionele ontwikkeling van docenten te bevorderen is van belang voor hen die werkzaam zijn op het gebied van docentenprofessionalisering en stafontwikkeling.

Focus van het onderzoek is het ontwerpen en ontwikkelen van een portfolio voor ervaren docenten op de universiteit. De procedure wordt uitgeprobeerd onder een kleine groep ervaren docenten aan een medische faculteit.

Het onderzoek kan worden gekarakteriseerd als Design Based Research (Barab \& Squire (Eds.), 2004; Sandoval, W. \& Bell, P. (Eds.)., 2004), ook wel aangeduid als ontwikkelingsonderzoek (Van den Akker, 1999). Dit type onderzoek bestaat uit een cyclisch proces van analyse, design, evaluatie en revisie. Het huidige onderzoek valt uiteen in drie fasen:

(1) Analyse \& design van een raamwerk van docentcompetenties en een prototype portfolio;

(2) Evaluatie van de bruikbaarheid van het portfolio voor formatieve doeleinden;

3) Analyse \& design van de portfoliobeoordelingsprocedure.

Fase 1: Analyse \& design van een raamwerk van docentcompetenties en een prototype portfolio

In de eerste analyse \& design fase is een raamwerk van docentcompetenties en een prototype portfolio ontwikkeld. Hoofdstuk 2 beschrijft een Delphi- 
onderzoek waarin onderwijskundige experts de belangrijkheid beoordeelden van een lijst docentcompetenties voor een ervaren docent in het hoger onderwijs. Na twee rondes waren de scores stabiel en werd consensus over $59 \%$ van de items bereikt. Vijf competentiedomeinen werden bevestigd in een confirmatorische factoranalyse op de drie hoogst scorende items in elk domein: 'Persoon als docent', 'Vakinhoudelijke deskundige', 'Begeleider van leerprocessen', 'Organisator' en 'Wetenschapper / levenslang lerende'. Het ontwikkelde competentieraamwerk bevat breed gedefinieerde items die bruikbaar zijn als vertrekpunt voor het beoordelen van docenten en voor het stellen van leerdoelen.

Hoofdstuk 3 behandelt de ontwikkeling van een prototype portfolio dat geschikt is voor zowel formatieve als summatieve doeleinden. Eerst definieerden we de theoretische uitgangspunten ten aanzien van het doel, de structuur, sociale interactie en assessment van het portfolio gebaseerd op Zeichner \& Wray (2001) en andere portfolioliteratuur. Op basis daarvan is een prototype portfolio ontwikkeld. Vervolgens werd in een interviewstudie het portfolioontwerp ter beoordeling voorgelegd aan portfolio experts. Hen werd gevraagd in welke mate de theoretische keuzes werden gereflecteerd in het prototype en welke aanpassingen nodig waren. Er was algemene consensus dat de essentie van de theoretische keuzes in het prototype terugkwamen. Echter, er waren enkele discussiepunten en aanbevelingen ten aanzien van het doel, de structuur, sociale interactie en assessment van het portfolio. Ten aanzien van doel was er discussie over de vraag of het mogelijk is formatieve en summatieve doelen in één portfolioprocedure te combineren. Met het oog op structuur wezen geïnterviewden erop dat voorbeeldvragen en suggesties voor bewijsmateriaal de creativiteit en leerprocessen van docenten in de weg zou kunnen staan. Hun advies om de voorbeeldvragen niet aan te bieden bij het uitproberen van het portfolio, maar alleen de domeinen te gebruiken, werd overgenomen. Bij sociale interactie rondom het portfolio zou volgens de portfolio experts ook gebruik moeten worden gemaakt van intervisie tussen collega-docenten. Bovendien leek het hen voor de veiligheid van de coachingsrelatie geen goed idee een coach advies te laten geven over de gecoachte docent aan de portfoliobeoordelingscommissie. Op basis van deze aanbevelingen werd het prototype aangepast. Met betrekking tot assessment zei men dat het op voorhand definiëren van beoordelingscriteria een negatief effect kan hebben: het zou docenten kunnen aanmoedigen om heel selectief te zijn in het kiezen van bewijsmaterialen voor het portfolio. Dat zou ten koste gaan van het rijke, valide beeld van een docent in een portfolio. Men was het erover eens dat feedback cruciaal is om portfoliobeoordelingen leerzame ervaringen te maken voor docenten. De beoordelingsprocedure diende echter nader uitgewerkt te worden. 
Fase 2: Evaluatie van de bruikbaarheid van het portfolio voor formatieve doeleinden De tweede fase van het onderzoek bestaat uit de evaluatie van de bruikbaarheid van het portfolio voor formatieve doeleinden. Twee aspecten van bruikbaarheid werden onderzocht: (1) reflecties van docenten; (2) de mening van deelnemers over de structuur en sociale interacties van het portfolio. Het portfolio werd op kleine schaal uitgeprobeerd. Vijf ervaren docenten en vijf coaches namen aan het onderzoek deel. Deelnemers maakten een set opdrachten die reflectie stimuleren: dieper nadenken over het eigen functioneren als docent. De docenten maakten een Tijdslijn, beschreven een Kritisch incident, ze stelden Leerdoelen, kozen Bewijsmateriaal, maakten een Competentieprofiel, en een compleet Portfolio op basis van de voorgaande opdrachten. Na iedere opdracht volgde een intervisiebijeenkomst of een gesprek met een persoonlijke coach.

In hoofdstuk 4 werd geëxploreerd op welke aspecten van hun functioneren docenten reflecteren tijdens hun werk als docent bij het maken van hun portfolio. We presenteerden illustratieve voorbeelden van de wijze waarop docenten reflecteren op verschillende aspecten van hun functioneren. De analyse resulteerde in voorbeelden van reflecties op alle aspecten van het functioneren (Korthagen, 2004): de omgeving, gedrag, competenties, overtuigingen, professionele identiteit en missie. Echter, voorbeelden van reflecties op competenties waren gemakkelijker te vinden dan die op overtuigingen, professionele identiteit en missie. Wellicht heeft de structurering van het portfolio volgens verschillende docentrollen de aandacht van docenten sterk op competenties gericht. De analyse van portfoliofragmenten kan bruikbaar zijn voor trainers en coaches van docenten in portfoliogesprekken over professionele ontwikkeling.

Het 5e hoofdstuk onderzoekt de mening van deelnemers over de opbrengst, bevorderende en belemmerde factoren van structuur en sociale interactie in relatie tot professionele ontwikkeling. Het portfolio was gestructureerd aan de hand van docentrollen, portfolio opdrachten, en gespreksprotocollen. Structuur was bedoeld om docenten op weg te helpen met het maken van hun portfolio zonder hun individuele leerprocessen in de weg te staan. Sociale interactie werd aangeboden in de vorm van intervisie tussen collega's die ook aan een portfolio werken en door middel van individuele coachgesprekken. Sociale interactie diende het effect van de opdrachten te versterken. Tijdens intervisiebijeenkomsten kwamen docenten bijeen om na te denken over zaken waar ze tijdens hun werk tegenaan lopen. Tijdens de coachgesprekken werden ze individueel kritisch bevraagd over hun eigen onderwijs en hoe te werken aan eigen leerdoelen. Iedere deelnemer koos zelf een coach die de organisatie goed kent en ervaren is op het gebied van onderwijs. Uiteraard moest die goed kunnen luisteren en vragen stellen. De gecoachte docent moest zich kwetsbaar kunnen opstellen tijdens de gesprekken en daarom mocht de coach geen beherend baas of directe collega zijn. De coachgesprekken werden gestructureerd door globale gespreksprotocollen. De 
vijf deelnemende docenten en hun persoonlijke coaches werden individueel geïnterviewd over hun ervaringen met het portfolio. De structuur en sociale interactie van het portfolio zag men als behulpzaam voor het analyseren van het eigen functioneren als docent, met name de coachingsgesprekken. De opdrachten en gespreksprotocollen werden echter als te directief en gedetailleerd ervaren. De positieve waardering van de coachgesprekken kan gerelateerd zijn aan de optie voor docenten om een eigen coach te kiezen. Het onderzoek resulteerde in een aantal praktische richtlijnen voor het vinden van een gebalanceerde structuur en het daarop afstemmen van sociale interacties.

\section{Fase 3: Analyse $\mathcal{E}$ design van de portfoliobeoordelingsprocedure}

De analyse \& design fase van het onderzoek wordt voorgezet in hoofdstuk 6, waarin de portfoliobeoordelingsprocedure verder werd ontwikkeld. Doel was het vinden van een benadering en geschikte kwaliteitscriteria voor summatieve portfoliobeoordeling die passen bij hedendaagse visies op docenten en docentenbeoordeling, de verwachte bijdrage van docentportfolio's aan de professionele ontwikkeling van docenten, en het rijke beeld dat portfolio's geven van praktijk van de docent. Op grond van een theoretische analyse beargumenteerden we dat een hermeneutische, interpretatieve benadering van portfoliobeoordeling aan de hand van criteria voor 'trustworthiness' van Guba \& Lincoln (1989) de meest geschikte is. Deze criteria zijn: credibility, dependability, confirmability en transferability. Credibility heeft betrekking op de mate waarin interpretaties van de assessoren matchen met die van verschillende belanghebbenden (stakeholders) in het veld. Dependability richt zich op vastleggen en documenteren van het interpretatieproces zodat nagegaan kan worden volgens welke stappen men tot een oordeel is gekomen. Dat is van belang voor confirmability: de mogelijkheid van bevestiging van de interpretaties en conclusies door de originele data. Transferability ten slotte vereist een uitgebreide beschrijving van de beoordelingssituatie en de conclusies daarvan zodat anderen kunnen nagaan of de uitkomsten van het assessment op hun situatie van toepassing zijn. Op basis van een analyse van voorbeelden van portfoliobeoordelingsprocedures waarin principes van constructivistische, hermeneutische benaderingen van assessment terugkomen deden we aanbevelingen voor het organiseren van docentportfoliobeoordelingsprocedures. Deze aanbevelingen resulteren in een beoordelingsprocedure die wordt gekarakteriseerd door uitwisseling van gezichtspunten, dialoog, en luisteren naar elkaar met zo weinig mogelijk machtsimbalans. Portfolioprocedures volgens constructivistische, hermeneutische principes en criteria kunnen een zorgvuldig en kwalitatief hoogstaand beoordelingsproces opleveren dat waardevol en leerzaam is voor alle betrokkenen. Ook zal zo'n procedure de integratie van formatieve en summatieve doeleinden ten goede komen. 


\section{Algemene discussie}

Hoofdstuk 7 vormt de algemene discussie van het proefschrift. Deze bestaat uit vijf onderdelen: de belangrijkste conclusies, een discussie van centrale dilemma's bij het ontwerpen en ontwikkelen van docentportfolio's, de beperkingen van het onderzoek, suggesties voor verder onderzoek, en praktische implicaties. Eerst bespreken we de hoofdconclusies uit de drie fasen van het onderzoek. Een docentportfolioprocedure die geschikt is voor zowel formatieve als summatieve doeleinden bevat een flexibele structuur die voldoende houvast biedt voor het stellen van leerdoelen en reflecteren op het eigen functioneren. Sociale interactie met collega's en een coach vinden regelmatig plaats rondom het maken van het portfolio om feedback te krijgen op eigen leerdoelen en functioneren. De kwaliteit van de portfolioprocedure wordt gewaarborgd aan de hand van de criteria voor 'trustworthiness' van Guba \& Lincoln (1989). Assessoren worden geselecteerd met expertise op het gebied van doceren die de kandidaten kennen. $Z \mathrm{ij}$ vormen hun interpretaties zorgvuldig en bekritiseren, bediscussiëren, en herzien die, bijvoorbeeld aan de hand van voorbeeldvragen en hypotheses. Kandidaten worden in het beoordelingsproces betrokken en krijgen de kans krijgen om informatie aan te vullen. Tevens worden kandidaten gecoached door iemand die ervaring heeft als docent en die de beoordelingsprocedure kent (Credibility). Stappen in het interpretatieproces worden gedocumenteerd om interne en externe checks door audits mogelijk te maken. Zo'n audit kan ook als beroepingsautoriteit voor kandidaten dienen (Dependability \& Confirmabilility). Uitgebreide informatie over de beoordelingssituatie en de argumenten voor het eindoordeel zijn beschikbaar (Transferability).

Drie dilemma's bij het ontwerpen en ontwikkelen van docentportfolioprocedures vormen formatieve versus summatieve assessment, de coach als steunverlener versus beoordelaar, en analytisch versus holistisch beoordelen.

De beperkingen van het onderzoek hebben betrekking op de uitwerking van de summatieve assessment procedure, het feit dat het prototype slechts twee keer getest en eenmaal in de praktijk is uitgeprobeerd en het bereik van het onderzoek. De aanbevelingen over de portfoliobeoordelingsprocedure dienen verder ontwikkeld en empirisch getoetst te worden. Zo kan het prototype verder geactualiseerd en getest worden. Het zou goed zijn om het prototype onder een grotere groep en in andere contexten verder te ontwikkelen.

Suggesties voor verder onderzoek omvatten verdere ontwikkeling van de portfoliobeoordelingsprocedure en de impact op langere termijn van portfolioprocessen op het leren en de ontwikkeling van docenten. Richtlijnen voor portfoliointerpretatie en -discussie moeten verder ontwikkeld worden. De interpretatieprocessen van assessoren tijdens het gebruik van die richtlijnen dienen onderzocht te worden. Het monitoren van de kwaliteit van portfolio 
assessment procedures volgens criteria voor 'trustworthiness' in plaats van psychometrische critera is tevens een interessant onderzoeksthema.

De praktische implicaties van het proefschrift worden beschreven aan de hand van de dimensies bij portfoliogebruik: doel, structuur, sociale interactie, en assessment.

Het hoofdstuk eindigt met een afsluitende opmerking over de implementatie van het portfolio. Een portfolioprocedure dient ingebed te zijn in de doelstellingen van de organisatie en een plaats te krijgen in het HRM-beleid van een instelling. We verwachten dat het toewerken naar een beoordeling volgens de principes van hermeneutisch, interpretatief onderzoek de ontwikkeling van de staf en hun committent voor docentschap zal laten toenemen. En dat is goed voor de kwaliteit van het onderwijs.

\section{Referenties}

Anderson, R., \& DeMeulle, L. (1998). Portfolio use in twenty-four teacher education programs. Teacher Education Quarterly, 25(1), 23-32.

Atkins, M. (1995). What should we be assessing. In P. Knight (Ed.), Assessment for learning in higher education (pp. 25-33). London: Kogan Page.

Barab, S., \& Squire, K. (Eds.). (2004). Design-Based Research: Clarifying the terms [Special issue]. The Journal of the Learning Sciences, 13(1).

Bartell, C., Kaye, C., \& Morin, J. A. (1998). Teaching portfolios in teacher education. Teacher Education Quarterly, 25(1), 5-8.

Biggs, J. (1996). Enhancing teaching through constructive alignment. Higher Education, 32, 347-364.

Biggs, J. (1999). Teaching for quality learning at University. Buckingham: SRHE Open University Press.

Birenbaum, M. (2003). New insights into learning and teaching and their implications for assessment. In M. Segers \& F. Dochy \& E. Cascallar (Eds.), Optimising new modes of assessment: In search of qualities and standards (pp. 13-36). Dordrecht/Boston/London.

Davies, A., \& LeMahieu, P. (2003). Assessment for learning: Reconsidering portfolios and research evidence. In M. Segers \& F. Dochy \& E. E. Cascallar (Eds.), Optimising new modes of assessment: In search of qualities and standards. Dordrecht/Boston/London: Kluwer Academic Publishers.

Dochy, F., Segers, M., \& Sluijsmans, D. (1999). The use of Self-, Peer and Co-assessment in Higher Education: a review. Studies in Higher Education, 24(3), 331-350.

Dochy, F. J. R. C., \& McDowell, L. (1997). Assessment as a tool for learning. Studies in Educational Evaluation, 67(23), 279-298.

Edgerton, R., Hutchings, P., \& Quinlan, K. (1991). The teaching portfolio: capturing the scholarship in teaching. Washington D.C.: AAHE.

Gipps, C. V. (1994). Beyond testing: Towards a theory of educational assessment. London, Washington D.C.: Falmer Press.

Guba, E. G. \& Lincoln, Y. S. (1989). Fourth generation evaluation. London Sage. 
Korthagen, F. A. J. (2004). In search of the essence of a good teacher: towards a more holistic approach in teacher education. Teaching and Teacher Education, 20, 77-97.

Sandoval, W. \& Bell, P. (Eds.). (2004). Design-based research mehods for studying learning in context [Special Issue]. Educational Psychologist, 39(4).

Seldin, P. (1991). The teaching portfolio: a practical guide to improved performance and promotion/tenure decisions. Bolton: MA: Anker.

Snyder, J., Lippincott, A., \& Bower, D. (1998). The inherent tensions in the multiple use of portfolios in teacher education. Teacher Education Quarterly, 25(1), 45-60.

Tynjälä, P. (1999). Towards experts knowledge? A comparison between a constructivist and a traditional learning environment in the university. International Journal of Educational Research, 31, 357-442.

Uhlenbeck, A. M., Verloop, N., \& Beijaard, D. (2002). Requirements for an Assessment Procedure for Beginning Teachers: Implications from recent theories on teaching and assessment. Teachers College Record, 104(2), 242-272.

Van den Akker, J. (1999). Principles and methods of development research. In J. Van den Akker \& R. B. Branch \& K. L. Gustafson \& N. M. Nieveen \& T. Plomp (Eds.), Design approaches and tools in education and training (pp. 1-14). Dordrecht, The Netherlands: Kluwer.

Wilkerson, J. R., \& Lang, W. S. (2003). Portfolios, the pied piper of teacher certification assessments: legal and psychometric issues. Educational Policy Analysis Archives, 11(45), retrieved [Date] from http;//epaa.asu/epaa/v11n45/.

Wolf, K., \& Dietz, M. (1998). Teaching portfolios; Purposes and Possibilities. Teacher Education Quarterly, 25(1), 9-22.

Zeichner, K., \& Wray, S. (2001). The teaching portfolio in US teacher education programs: what we know and what we need to know. Teaching and Teacher Education, 17, 613-621. 


\section{Publications}

\section{Scientific publications}

Tigelaar, E.H., Dolmans, D.H.J.M., Wolfhagen, H.A.P., \& Van der Vleuten, C.P.M. (2004). The development and validation of a framework for teaching competencies in higher education. Higher Education, 48, 253-268.

Tigelaar, E.H., Dolmans, D.H.J.M., Wolfhagen, H.A.P., \& Van der Vleuten, C.P.M. (2004). Using a conceptual framework and the opinions of portfolio experts to develop a teaching portfolio prototype. Studies in Educational Evaluation, 30 (3), 305-321.

Tigelaar, E.H., Dolmans, D.H J.M., Wolfhagen, H.A.P., \& Van der Vleuten, C.P.M. (2005). Quality issues in judging portfolios: implications for organizing teaching portfolio assessment procedures. Studies in Higher Education, 30(5), 595-610.

Tigelaar, E.H., Dolmans, D.H J.M., De Grave, W.S., Wolfhagen, H.A.P., \& Van der Vleuten, C.P.M. (In Press). Portfolio as a tool to stimulate teachers' reflections. Medical Teacher.

Tigelaar, E.H., Dolmans, D.H J.M., De Grave, W.S., Wolfhagen, H.A.P., \& Van der Vleuten, C.P.M. (In Press). Participants' opinions about the usefulness of a teaching portfolio. Medical Education.

\section{Bookchapters}

Tigelaar, E.H., Dolmans, D.H.J.M. \& Wolfhagen, H.A.P. (In Preparation). Kwaliteit van onderwijs en docentcompetenties. In: Onderwijskunde Hoger Onderwijs. Handboek voor docenten (3e druk). Van Hout, H., Ten Dam, G., Terlouw, C. \& Willems, J. Assen: Van Gorcum.

\section{Other publications}

Martens, R., Tigelaar, D., Stoof, A., Hoogveld, B. (2003). De dubbele bodem van competentiegericht onderwijs. [The double bottom in competency-based education]. Onderwijs Innovatie, Jg.11, No. 3, p. 11-12.

Tigelaar, E.H. (2005). Docentportfolio's: goed voor de kwaliteit van onderwijs? [Teaching portfolios: improving quality in education?] HRM-Courant Maastricht University, No. 2.

\section{Book review}

Tigelaar, D., Brouwer, J., Dolmans, D. (2002). Boekbespreking The development of an assessment procedure for beginning teachers of English as a foreign language, Academisch proefschrift A.M. Uhlenbeck. Pedagogische Studiën, Jg. 79, No. 5, p. 406-408.

\section{Presentations}

Tigelaar, E.H., Dolmans, D.H.J.M., Wolfhagen, H.A.P., \& Van der Vleuten, C.P.M. (2001). Naar een inventarisatie van docentcompetenties in student-gecentreerd hoger onderwijs. [Toward an inventory of teaching competencies in student-centred higher education]. Posterpresentation at the $11^{\text {th }}$ Dutch Association for Medical Education (NVMO) Conference, Veldhoven, The Netherlands. 
Tigelaar, E.H., Dolmans, D.H.J.M., Wolfhagen, H.A.P., \& Van der Vleuten, C.P.M. (2002). The development and validation of a framework for teaching competencies in higher education. Paper presented at the $5^{\text {th }}$ Junior Researchers Conference of EARLI (JURE), Amsterdam, The Netherlands.

Tigelaar, E.H., Dolmans, D.H.J.M., Wolfhagen, H.A.P., \& Van der Vleuten, C.P.M. (2002). Een inventarisatie van docentcompetenties in student-gecentreerd hoger onderwijs. [An inventory of teaching competencies in student-centred higher education]. Posterpresentation at the 29th Dutch-Flemish Educational Research Days (ORD), Antwerpen, Belgium.

Tigelaar, E.H., Dolmans, D.H.J.M., Wolfhagen, H.A.P., \& Van der Vleuten, C.P.M. (2003). De ontwikkeling van een docentportfolio voor hoger onderwijs met competentiedomeinen als uitgangspunt. [The development of a teaching portfolio using competency domains as a point of departure]. Paper presented at the 30th Dutch-Flemish Educational Research Days (ORD), Kerkrade, The Netherlands.

Tigelaar, E.H., Dolmans, D.H.J.M., Wolfhagen, H.A.P., \& Van der Vleuten, C.P.M. (2003). The development of a model for a teaching portfolio. Paper presented at the $11^{\text {th }}$ International Study Association on Teachers and Teaching (ISATT) Conference, Leiden, The Netherlands.

Tigelaar, E.H., Dolmans, D.H.J.M., Wolfhagen, H.A.P., \& Van der Vleuten, C.P.M. (2003). The development of a prototype for a teaching portfolio. Paper presented at the $10^{\text {th }}$ Biannual Conference of the European Association for Research on Learning and Instruction (EARLI). Padua, Italy.

Tigelaar, E.H., Dolmans, D.H J.M., Wolfhagen, H.A.P., \& Van der Vleuten, C.P.M. (2003). Dilemma's bij de ontwikkeling van een docentportfolio voor hoger onderwijs. [Dilemmas in the design of a teaching portfolio for higher education\}. Paper presented at the $13^{\text {th }}$ Dutch Association for Medical Education (NVMO) Conference, Egmond aan Zee, The Netherlands.

Tigelaar, E.H., Dolmans, D.H J.M., Wolfhagen, H.A.P., \& Van der Vleuten, C.P.M. (2004). Aanbevelingen voor docentportfolio assessment procedures: implicaties van recente discussies over validiteitsonderzoek en docentevaluatie-literatuur. [Recommendations for teaching portfolio assessment procedures: implications from recent discussions on validity inquiry and teacher assessment literature]. Paper presented at the $31^{\text {th }}$ Dutch-Flemish Educational Research Days (ORD), Utrecht, The Netherlands.

Tigelaar, E.H., Dolmans, D.H J.M., Wolfhagen, H.A.P., \& Van der Vleuten, C.P.M. (2004). Organizing teacher portfolio assessment procedures: implications from current validity inquiry discussions and literature on teacher evaluation. Paper presented at the $2^{\text {nd }}$ Biannual Northumbria/EARLI SIG Assessment Conference. Bergen, Norway.

Tigelaar, E.H., Dolmans, D.H J.M., Wolfhagen, H.A.P., \& Van der Vleuten, C.P.M. (2004). Kwaliteitsvraagstukken bij portfolio beoordelingen: implicaties voor het organiseren van docentportfolio-beoordelingsprocedures. [Quality issues in judging portfolios: implications for organizing teaching portfolio assessment procedures]. Paper presented at the $14^{\text {th }}$ Dutch Association for Medical Education (NVMO) conference, Egmond aan Zee, The Netherlands.

Tigelaar, E.H., Dolmans, D.H J.M., De Grave, W.S., Wolfhagen, H.A.P., \& Van der Vleuten, C.P.M. (2005). Portfolio als middel om reflectie te stimuleren. Illustraties uit een exploratief onderzoek. [Portfolio as a tool to stimulate reflections. Illustrations from an exploratory study]. Paper presented at the $32^{\text {nd }}$ Dutch-Flemish Educational Research Days (ORD), Gent, Belgium. 
Tigelaar, E.H., Dolmans, D.H J.M., Wolfhagen, H.A.P., \& Van der Vleuten, C.P.M. (2005). Quality issues in judging portfolios: implications for organizing teaching portfolio assessment procedures. Paper presented at the $11^{\text {th }}$ Biannual Conference of the European Association for Research on Learning and Instruction (EARLI). Nicosia, Cyprus. 
- 


\section{Curriculum vitae}

Dineke Tigelaar was born on the 10th of October, 1975, in Assen, the Netherlands. In 1994 she finished secondary education at the Gomarus College in Groningen. From 1994 until 2000 she studied Educational Sciences at the University of Groningen (Rijksuniversiteit Groningen). Her thesis, written at CPS, Educational Development and Advice in Amersfoort, concerned the use of a language portfolio for learning English as a foreign language at primary and secondary education. After her graduation, she started her PhD-project on the design and evaluation of a teaching portfolio at the Department of Educational Development and Research at the University of Maastricht. Currently, she works as an Assistant Professor at the ICLON, Graduate School of Education at Leiden University. Her main areas of research interest are portfolio assessment and teachers' professional development.

Dineke Tigelaar werd geboren op 10 oktober 1975 te Assen. In 1994 slaagde ze voor haar VWO-examen op het Gomarus College te Groningen. Tussen 1994 en 2000 studeerde ze Onderwijskunde aan de Rijksuniversiteit Groningen. Haar afstudeerscriptie, geschreven bij CPS Onderwijsontwikkeling en Advies te Amersfoort, gaat over het gebruik van een taalportfolio voor het Engelse taalonderwijs op het basis- en voortgezet onderwijs. Na haar afstuderen begon ze als Promovendus aan haar project over het ontwerp en de evaluatie van een docentportfolio bij de Capaciteitsgroep Onderwijsontwikkeling en Onderwijsresearch van de Universiteit Maastricht. Momenteel werkt ze als Universitair Docent bij het Interfacultair Centrum voor Lerarenopleiding, Onderwijsontwikkeling en Nascholing (ICLON) van de Universiteit Leiden. Haar belangrijkste onderzoeksterreinen zijn portfolio-assessment en professionele ontwikkeling van docenten. 


\section{ICO Dissertation Series}

In the ICO Dissertation Series dissertations are published of graduate students from faculties and institutes on educational research within the following universities: University of Twente, University of Groningen, Maastricht University, University of Amsterdam, Utrecht University, Open University, Leiden. University, Wageningen University, Technical University of Eindhoven, and Free University (and formerly University of Nijmegen and University of Tilburg). Over one hundred dissertations have been published in this series. The most recent ones are listed below.

93. Fukkink, R.G. (02-02-2002). Instructing Primary School Children in Deriving Word Meaning from Written Context. Amsterdam: University of Amsterdam.

94. Vosse, A.J.M. (10-04-2002). Evaluatie van het Tutorleren in Nederland: Een onderzoek naar de cognitieve en sociaal-emotionele effecten van een tutorprogramma voor rekenen-wiskunde in het basisonderwijs. Amsterdam: University of Amsterdam.

95. Jager, B. de (25-04-2002). Teaching Reading Comprehension: The Effects of Direct Instruction and Cognitive Apprenticeship on Comprehension Skills and Metacognition. Groningen: University of Groningen.

96. Veldhuis-Diermanse, E.A. (26-04-2002). CSCLearning? Participation, Learning Activities and Knowledge Construction in Computer-Supported Collaborative Learning in Higher Education. Wageningen: Wageningen University.

97. Crombach, M.J. (02-05-2002). Sixth and Seventh Graders' Appraisal Processes of Curricular Tasks: Development of a Model to Explain Students' Willingness to Invest Effort. Nijmegen: University of Nijmegen.

98. Kruiter, J.H. (13-05-2002). Groningen Community Schools: Influence on Child Behaviour Problems and Education at Home. Groningen: University of Groningen.

99. Braaksma, M.A.H. (21-05-2002). Observational Learning in Argumentative Writing. Amsterdam: University of Amsterdam.

100. Lankhuijzen, E.S.K. (24-05-2002). Learning in Self-Managed Managenent Career: The Relation between Managers' HRD-Patterns, Psychological Career Contracts and Mobility Perspectives. Utrecht: Utrecht University.

101. Gellevij, M.R.M. (06-06-2002). Visuals in Instruction: Functions of Screen Captures in Software Manuals. Enschede: University of Twente.

102. Vos, F.P. (26-06-2002). Like an Ocean Liner Changing Course: The Grade 8 Mathematics Curriculum in the Netherlands, 1995-2000. Enschede: University of Twente.

103. Sluijsmans, D.M.A. (28-06-2002). Student Involvement in Assessment: The Training of Peer Assessment Skills. Heerlen: Open University.

104. Tabbers, H.K. (13-09-2002). The Modality of Text in Multimedia Instructions: Refining the Design Guidelines. Heerlen: Open University. 
105. Verhasselt, E. (14-11-2002). Literacy Rules: Flanders and the Netherlands in the International Adult Literacy Survey. Groningen: University of Groningen.

106. Beekhoven, S. (17-12-2002). A Fair Chance of Succeeding: Study Careers in Dutch Higher Education. Amsterdam: University of Amsterdam.

107. Veermans, K.H. (09-01-2003). Intelligent Support for Discovery Learning: Using Opportunistic Learner Modeling and Heuristics to Support Simulation Based Discovery Learning. Enschede: University of Twente.

108. Tjepkema, S. (10-01-2003). The Learning Infrastructure of Self-Managing Work Teams. Enschede: University of Twente.

109. Snellings, P.J.F. (22-01-2003). Fluency in Second Language Writing: The Effects of Enhanced Speed of Lexical Retrieval. Amsterdam: University of Amsterdam.

110. Klatter, E.B. (23-01-2003). Development of Learning Conceptions during the Transition from Primary to Secondary Education. Nijmegen: University of Nijmegen.

111. Jellema, F.A. (21-02-2003). Measuring Training Effects: the Potential of 360-degree Feedback. Enschede: University of Twente.

112. Broekkamp, H.H. (25-02-2003). Task Demands and Test Expectations: Theory and Empirical Research on Students' Preparation for a Teacher-made Test. Amsterdam: University of Amsterdam.

113. Odenthal, L.E. (21-03-2003). Op zoek naar balans: Een onderzoek naar een methode ter ondersteuning van curriculumvernieuwing door docenten. Enschede: University of Twente.

114. Kuijpers, M.A.C.T. (21-03-2003). Loopbaanontwikkeling: onderzoek naar 'Competenties'. Enschede: University of Twente.

115. Jepma, IJ. (01-07-2003). De schoolloopbaan van risico-leerlingen in het primair onderwijs. Amsterdam: University of Amsterdam.

116. Sotaridona, L.S. (05-09-2003). Statistical Methods for the Detection of Answer Copying on Achievement Tests. Enschede: University of Twente.

117. Kester, L. (05-09-2003). Timing of Information Presentation and the Acquisition of Complex Skills. Heerlen: Open University.

118. Waterreus, J.M. (05-09-2003). Lessons in Teacher Pay: Studies on Incentives and the Labor Market for Teachers. Amsterdam: University of Amsterdam.

119. Toolsema, B. (23-10-2003). Werken met competenties. Enschede: University of Twente.

120. Taks, M.M.M.A. (20-11-2003). Zelfsturing in leerpraktijken: Een curriculumonderzoek naar nieuwe rollen van studenten en docenten in de lerarenopleiding. Enschede: University of Twente.

121. Driessen, C.M.M. (21-11-2003). Analyzing Textbook Tasks and the Professional Development of Foreign Language Teachers. Utrecht: Utrecht University.

122. Hubers, S.T.T. (24-11-2003). Individuele leertheorieën en het leren onderzoeken in de tweede fase. Eindhoven: Technical University of Eindhoven.

123. Sun, H. (04-12-2003). National Contexts and Effective School Improvement: An Exploratory Study in Eight European Countries. Groningen: University of Groningen.

124. Bruinsma, M. (09-12-2003). Effectiveness of Higher Education: Factors that Determine Outcomes of University Education. Groningen: University of Groningen.

125. Veneman, H. (01-07-2004). Het gewicht van De Rugzak: Evaluatie van het beleid voor leerlinggebonden financiering. Groningen: University of Groningen. 
126. Annevelink, E. (27-08-2004). Class Size: Linking Teaching and Learning. Enschede: University of Twente.

127. Emmerik, M.L. van (22-09-2004). Beyond the Simulator: Instruction for High Performance Tasks. Enschede: University of Twente.

128. Vries, B. de (15-10-2004). Opportunities for Reflection: E-mail and the Web in the Primary Classroom. Enschede: University of Twente.

129. Veenhoven, J. (05-11-2004). Begeleiden en beoordelen van leerlingonderzoek: Een interventiestudie naar het leren ontwerpen van onderzoek in de tweede fase van het voortgezet onderwijs. Utrecht: Utrecht University.

130. Strijbos, J.W. (12-11-2004). The Effect of Roles on Computer-Supported Collaborative Learning. Heerlen: Open University.

131. Hamstra, D.G. (22-11-2004). Gewoon en Anders: Integratie van leerlingen met beperkingen in het regulier onderwijs in Almere. Groningen: University of Groningen.

132. Lubbers, M.J. (09-12-2004). The Social Fabric of the Classroom: Peer Relations in Secondary Education. Groningen: University of Groningen.

133. Nijman, D.J.J.M. (10-12-2004). Supporting Transfer of Training: Effects of the Supervisor. Enschede: University of Twente.

134. Dewiyanti, S. (25-02-2005). Learning Together: A positive experience. The effect of reflection on group processes in an asynchronous computer-supported collaborative learning environment. Heerlen: Open University.

135. Stoof, A. (04-03-2005). Tools for the identification and description of competencies. Heerlen: Open University.

136. Groot, R.W.A. de (10-03-2005). Onderwijsdecentralisatie en lokaal beleid. Amsterdam: Universiteit van Amsterdam.

137. Salden, R.J.C.M. (22-04-2005). Dynamic Task Selection in Aviation Training. Heerlen: Open University.

138. Gijlers, A.H. (23-09-2005). Confrontation and co-construction: Exploring and supporting collaborative scientific discovery learning with computer simulations. Enschede: University of Twente.

139. Stevenson, M.M.C. (27-09-2005). Reading and writing in a foreign language: A comparison of conceptual and linguistic processes in Dutch and English. Amsterdam: University of Amsterdam. 